\title{
LITHOLOGY, FAULT DISPLACEMENT, AND ORIGIN OF SECONDARY CALCIUM CARBONATE AND OPALINE SILICA AT TRENCHES 14 AND 14D ON THE BOW RIDGE FAULT AT EXILE HILL, NYE COUNTY, NEVADA
}

U.S. GEOLOGICAL SURVEY

Open-File Report 93-477

Prepared in cooperation with the NEVADA OPERATIONS OFFICE, U.S. DEPARTMENT OF ENERGY, under Interagency Agreement DE-AI08-78ET44802

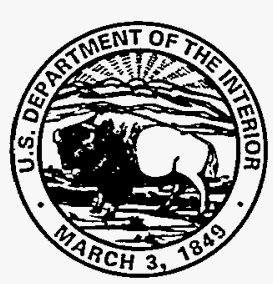




\section{DISCLAIMER}

This report was prepared as an account of work sponsored by an agency of the United States Government. Neither the United States Government nor any agency thereof, nor any of their employees, makes any warranty, express or implied, or assumes any legal liability or responsibility for the accuracy, completeness, or usefulness of any information, apparatus, product, or process disclosed, or represents that its use would not infringe privately owned rights. Reference herein to any specific commercial product, process, or service by trade name, trademark, manufacturer, or otherwise does not necessarily constitute or imply its endorsement, recommendation, or favoring by the United States Government or any agency thereof. The views and opinions of authors expressed herein do not necessarily state or reflect those of the United States Government or any agency thereof. 


\section{DISCLAIMER}

Portions of this document may be illegible in electronic image products. Images are produced from the best available original document. 


\section{Lithology, Fault Displacement, and Origin of Secondary Calcium Carbonate and Opaline Silica at Trenches 14 and 14D on the Bow Ridge Fault at Exile Hill, Nye County, Nevada}

\section{by Emily M. Taylor and Heather E. Huckins}

\section{U.S. GEOLOGICAL SURVEY}

Open-File Report 93-477

Prepared in cooperation with the NEVADA OPERATIONS OFFICE, U.S. DEPARTMENT OF ENERGY, UNDER INTERAGENCY AGREEMENT DE-AI08-78ET44802

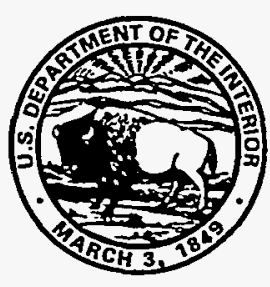




\title{
U.S. DEPARTMENT OF THE INTERIOR \\ BRUCE BABBITT, Secretary
}

\author{
U.S. GEOLOGICAL SURVEY \\ Gordon P. Eaton, Director
}

The use of trade, product, industry, or firm names is for descriptive purposes only and does not imply endorsement by the U.S. Government.

For additional information write to:

Copies of this report can be purchased from:

Chief, Hydrologic Investigations Program

Yucca Mountain Project Branch

U.S. Geological Survey

Box 25046, MS 421

Denver Federal Center

Denver, CO 80225

U.S. Geological Survey

Earth Science Information Center

Open-File Reports Section

Box 25286, MS 517

Denver Federal Center

Denver, CO 80225 


\section{CONTENTS}

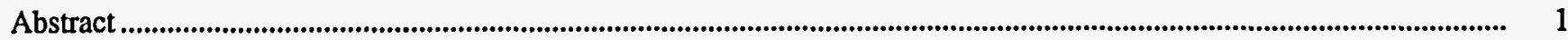

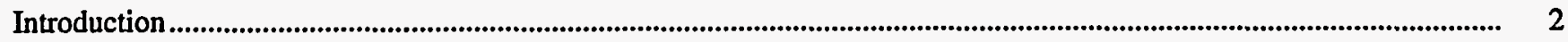

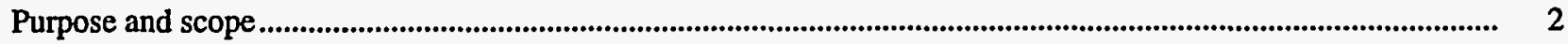

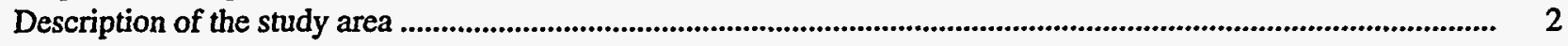

Acknowledgments....................................................................................................................................................... 4

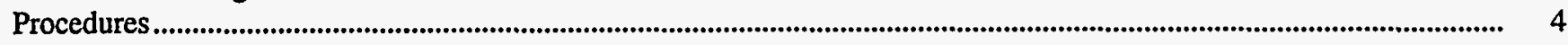

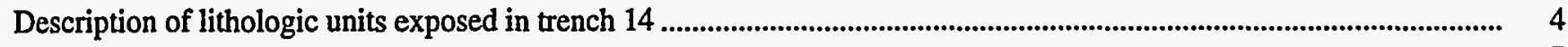

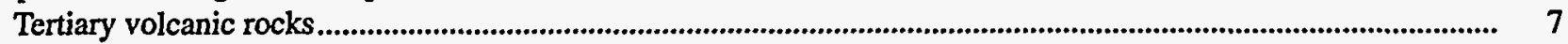

Highly fractured nonwelded tuff........................................................................................................ 7

Slightly fractured intact Tiva Canyon Member of the Paintbrush Tuff .......................................................... 7

Highly fractured Tiva Canyon Member of the Paintbrush Tuff........................................................................ 8

Carbonate-cemented and fractured Tiva Canyon Member of the Paintbrush Tuff............................................ $\quad 8$

Densely carbonate-cemented and fractured Tiva Canyon Member of the Paintbrush Tuff............................... 9

Fault zone-breccia and veins ....................................................................................................................................... 9

Nonwelded tuff fault breccia................................................................................................................................. 9

Uncemented Tiva Canyon Member fault breccia ............................................................................................. 9

Silica-cemented Tiva Canyon Member fault breccia ............................................................................................ 9

Cemented cataclastic fault breccia ................................................................................................... 9

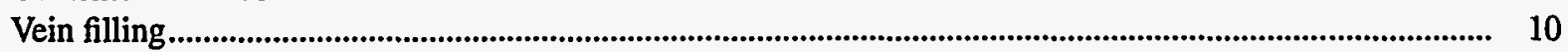

Slope-wash alluvium and colluvium.......................................................................................................... 11

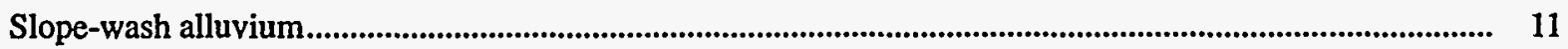

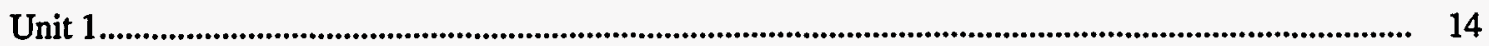

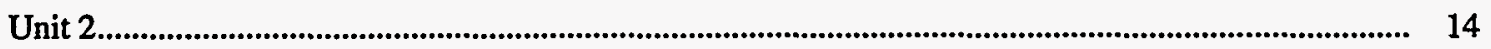

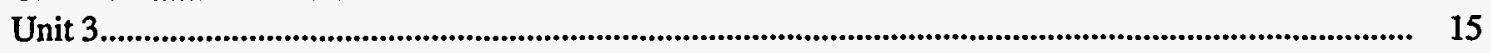

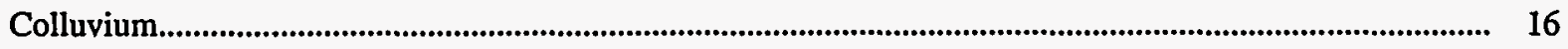

Origin of secondary calcium carbonate and opaline silica ............................................................................... 16

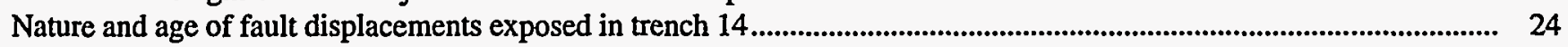

Phases of faulting ................................................................................................................................................................... 24

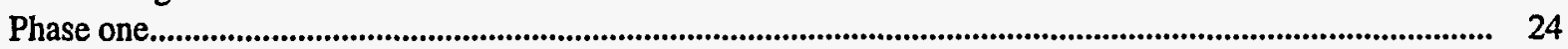

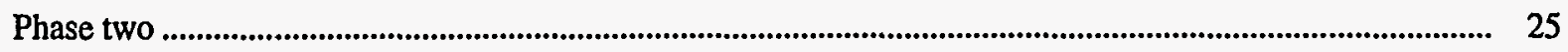

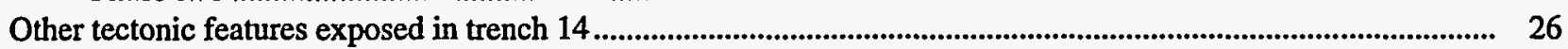

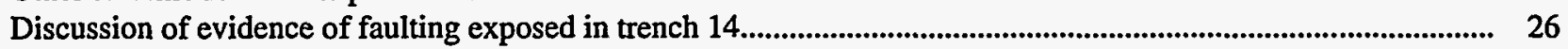

Description of the lithologic units exposed in trench 14D....................................................................................................... 27

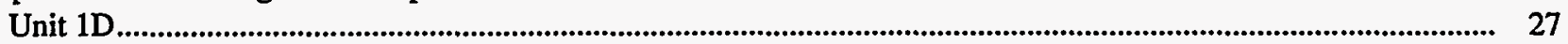

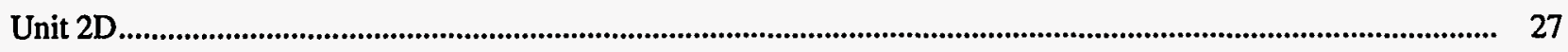

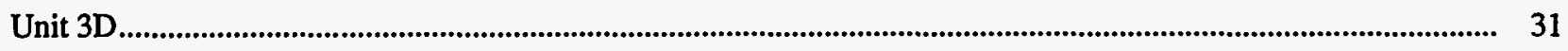

Unit 4D ...................................................................................................................................................................... 31

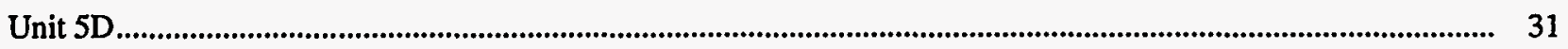

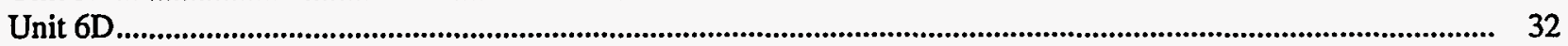

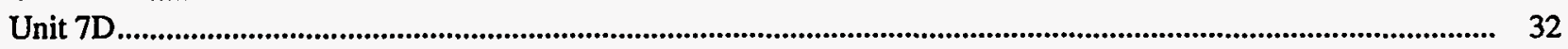

Nature and age of fault displacements exposed in trench 14D ..........................................................................................

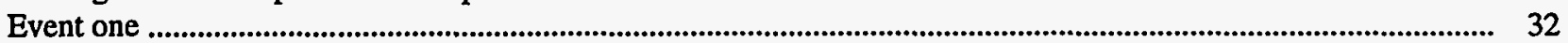

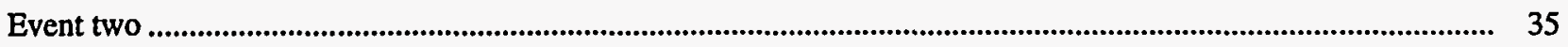

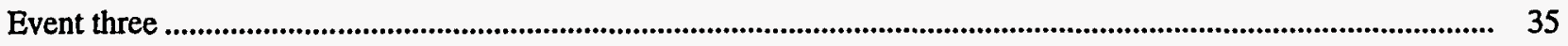

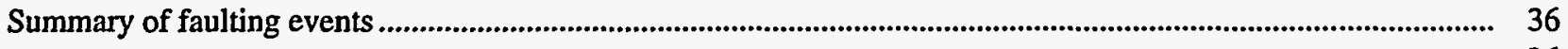

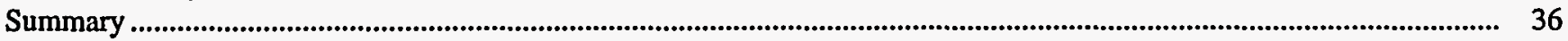

References cited .................................................................................................................................................................. 37 


\section{PLATE}

(in pocket)

1. Geologic section showing the north and south walls exposed in trench 14 on the Bow Ridge Fault at Exile Hill, Nye County, Nevada

\section{FIGURES}

1. Map showing location of study area

2. Photograph of the Bow Ridge Fault bedrock scarp at Bow Ridge .................................................................

3. Aerial photograph of Exile Hill and the locations of trenches 14, 14A, 14B, 14C, and 14D.

4. Index map of trench logs for use with plate 1

5-9. Photographs of:

5. A characteristic section of slope-wash alluvium

6. The main fault exposed on the north wall center section of trench 14

7. The main fault exposed on the south wall center section of trench 14

8. A typical vein filling exposed in trench 14 .

9. Dense opaline stringers exposed on the south wall of trench 14

10. Photomicrograph of microcrystalline banded carbonate with a crystallitic $b$-fabric

11. Photomicrograph of botryoidal opal filling a void.

12. Representative X-ray diffraction trace showing opal-CT from an opaline silica stringer in trench 14

13. Stereonet projection showing compilation and comparison of fracture orientations in the bedrock and slope-wash alluvium exposed in trench 14

14. Log of the south wall of trench 14D

15. Proposed sequential development of the fault and the surficial deposits exposed on the south wall of trench 14D

\section{TABLES}

1. General characteristics of stages of pedogenic opaline silica development

2. Field description of a characteristic soil exposed in the slope-wash alluvium in trench 14 .

3. Selected grain-size data, bulk density, and calcium carbonate content from a characteristic soil exposed in the slope-wash alluvium in trench 14

4. Uranium-trend and uranium-series ages for deposits exposed in trench 14

5. General criteria for distinguishing nonpedogenic from pedogenic calcium carbonate and opaline silica ...

6. Orientations of fractures in the slope-wash alluvium exposed on the north and south walls of trench 14.

7. Dominant physical characteristics and percentages of calcium carbonate in the deposits exposed in trench 14D 


\section{CONVERSION FACTORS AND ACRONYMS}

\begin{tabular}{rll}
\hline Multiply & By & To obtain \\
\hline & & \\
centimeter $(\mathrm{cm})$ & 0.394 & inch \\
kilometer $(\mathrm{km})$ & 0.621 & mile \\
meter $(\mathrm{m})$ & 3.28 & foot \\
millimeter $(\mathrm{mm})$ & 0.0394 & inch \\
\hline
\end{tabular}

Degree Celsius $\left({ }^{\circ} \mathrm{C}\right)$ may be converted to degree Fahrenheit $\left({ }^{\circ} \mathrm{F}\right)$ by using the following equation:

$$
{ }^{\circ} \mathrm{F}=9 / 5\left({ }^{\circ} \mathrm{C}\right)+32 \text {. }
$$

The following terms and abbreviations also are used in this report.

$\mathrm{g} / \mathrm{cm}^{3} \quad$ gram per cubic centimeter

ka thousands of years old

m.y. millions of years ago

$\mathrm{Ma}$ millions of years old 


\title{
Lithology, Fault Displacement, and Origin of Secondary Calcium Carbonate and Opaline Silica at Trenches 14 and 14D on the Bow Ridge Fault at Exile Hill, Nye County, Nevada
}

\author{
By Emily M. Taylor and Heather E. Huckins
}

\section{Abstract}

Trenches were excavated in the Yucca Mountain region as part of the Yucca Mountain Site Characterization Project. Trench 14, which was excavated across the Bow Ridge Fault on the west side of Exile Hill, exposes nearly vertical veins containing calcium carbonate, opaline silica, and fine-grained sediments. Although the original purpose of the excavation of trench 14 was to evaluate the nature and frequency of Quaternary movement on the Bow Ridge Fault, concern arose as to whether the calcium carbonate-enriched deposits at and adjacent to the fault zone were deposited by springs. Spring deposits of Quaternary age would indicate that water, in the recent geologic past, had reached the surface from below.

From east to west, trench 14 exposes

(1) fractured volcanic tuffs; (2) a main fault zone marked by discrete nearly vertical veins within brecciated bedrock; and (3) colluvium and slopewash alluvium. The brecciated bedrock has been locally recemented by secondary calcium carbonate and opaline silica, especially within the main fault. The fault zone is filled by a prominent mass of banded calcium carbonate and opaline silica veins, that is about 2.5 meters wide on the north wall and splays into a zone about 4 meters wide, consisting of five main veins on the south wall. The well-cemented slope-wash alluvium adjacent to the main fault is sandy and contains a large component of angular rock fragments. Coarser colluvial deposits, which are present adjacent to the bedrock scarp located at the base of the slope-wash alluvium, pinch out west of the main fault. Soil formed in the slope-wash alluvium has a welldeveloped $K$ horizon that is cemented by secondary calcium carbonate and opaline silica. The slope-wash alluvium and veins are unconformably overlain by a finer grained depositional unit consisting of slope wash and eolian sand and silt.

Physical, chemical, mineralogic, biologic, petrographic, and isotopic data were collected to determine the origin of the calcium carbonate and opaline silica in the veins and slope-wash alluvium. These data were used to determine general properties that are characteristic of pedogenic deposits. The colluvial deposit is laterally persistent, the concentration of secondary calcium carbonate decreases with depth below a maximum concentration, and discrete soil horizons are present. The initial deposition of calcium carbonate occurs on the underside of clasts, and the clasts within the deposit have been displaced by the precipitation of the secondary calcium carbonate and are no longer in clast-to-clast contact. The calcium carbonate in the veins and in the slope-wash alluvium contains ooids, primarily opal-CT, and sepiolite; it is well stratified and has a microcrystalline crystallitic $b$-fabric. Opaline silica concentrations in the veins and slope-wash alluvium are typical of pedogenic duripans, not silcretes. Oxygen, lead, strontium and uranium, isotopic data indicate that the calcium carbonate in trench 14 were precipitated from meteoric water rather than ground water. Carbon isotopic data indicate that the meteoric water had equilibrated with root-zone carbon dioxide. No ostracodes, which are characteristic of spring deposits, have been found. Therefore, the calcium carbonate and opaline silica present in the veins and in the slope-wash alluvium in trench 14 are most likely products of pedogenic processes. The calcium carbonate is primarily from wind blown dust that moves in solution and has been precipitated from downward percolating meteoric water, rather than originating from ground water. 
Conspicuously, well-laminated calcium carbonate and opaline silica have been deposited along the fault plane in trench 14. Because the unconsolidated sandy slope-wash alluvium could not support an open fracture very long, these laminae probably record episodes of opening and incremental filling of fractures that developed along the Bow Ridge Fault. However, each lamina probably does not record a single fracturing event. The fault zone and fractures contain a tentatively dated black ash that is chemically indistinguishable from ashes derived from the Crater Flat cinder cones and thought to be 1.1 and 1.3 millions of years old, and the Lathrop Wells Cone dated from 30,000 to 130,000 years old. The ash-filled fractures are crosscut in places by fractures that contain fine-grained sediments and secondary calcium carbonate, and they are the only fractures that extend through the platy $K$ soil horizon. The ash is probably coeval with one of the most recent fracturing events recorded in the trench. The ashfilled fractures also indicate that tectonic events produced open fractures that were subsequently filled by pedogenic translocation of calcium carbonate, opaline silica, and fine-grained sediment, rather than these deposits resulting from action of ground water.

Two general azimuth orientations are observed in the fractures in trench 14. About 85 percent of the bedrock fractures are oriented northwest; the remainder in the bedrock and all the fractures in the slope-wash alluvium are oriented northeast.

Trench 14D, $50 \mathrm{~m}$ south of trench 14, exposes the Bow Ridge Fault in Quaternary slopewash alluvium, channel alluvium, and colluvium. Trench 14D exposes evidence of three faulting events, separated by periods of deposition and surface stability. It can be estimated by correlating dated units in trench 14 to those exposed in trench $14 \mathrm{D}$ that at least $51 \mathrm{~cm}$ of vertical offset, down to the west, has occurred since the stabilization of the basal unit dated between $270,000 \pm 90,000$ and $480,000 \pm 90,000$ years ago. A unit above the basal unit, thought to be about $150 \mathrm{ka}$, is offset $12 \mathrm{~cm}$. The basal unit was initially offset at least $13 \mathrm{~cm}$ between about 270,000 and 150,000 years ago, and $12 \mathrm{~cm}$ since about 150,000 years ago. There is no evidence of displacement of Holocene age.

\section{INTRODUCTION}

Yucca Mountain, a proposed site for a high-level nuclear-waste repository, is located in southern Nevada, $20 \mathrm{~km}$ east of Beatty, and adjacent to the southwest corner of the Nevada Test Site (NTS) (fig. 1). Yucca Mountain is located within the Basin and Range province of the western United States. The climate is semiarid, and the flora is transitional between that of the Mojave Desert to the south and the Great Basin Desert to the north. As part of the evaluation, hydrologic conditions, especially water levels, of Yucca Mountain and vicinity during the Quaternary, and especially the past 20,000 years, are being characterized.

In 1982, the U.S. Geological Survey, in cooperation with the U.S. Department of Energy (under interagency agreement DE-A104-78ET44802), excavated twenty-six bulldozer and backhoe trenches in the Yucca Mountain region to evaluate the nature and frequency of Quaternary faulting (Swadley and others, 1984). The trenches were oriented perpendicular to traces of suspected Quaternary faults and across projections of known bedrock faults into Quaternary deposits. Trench 14 exposes the Bow Ridge Fault on the west side of Exile Hill (fig. 1). Preliminary mapping of trench 14 was done by Swadley and others (1984). Although the original purpose of the excavation of trench 14 was to evaluate the nature and frequency of Quaternary faulting on the Bow Ridge Fault, concern arose as to whether or not the nearly vertical calcium carbonate (the term "carbonate" in this study refers to calcium carbonate) and opaline silica veins in the fault zone were deposited by ascending waters (ground water). These veins resemble in gross morphology veins commonly formed by hydrothermal processes.

\section{Purpose and Scope}

This report presents (1) detailed logs of the north and south walls of trench 14 and the south wall of trench 14D, (2) descriptions of the lithologic units, (3) a discussion of the origin of the secondary carbonate and opaline silica, and (4) a discussion of the nature and age of fault displacement exposed in trenches 14 and 14D.

\section{Description of the Study Area}

The Bow Ridge Fault is a north-northeasttrending normal fault, about $10 \mathrm{~km}$ long, located on the east side of Yucca Mountain. Numerous carbonate- 


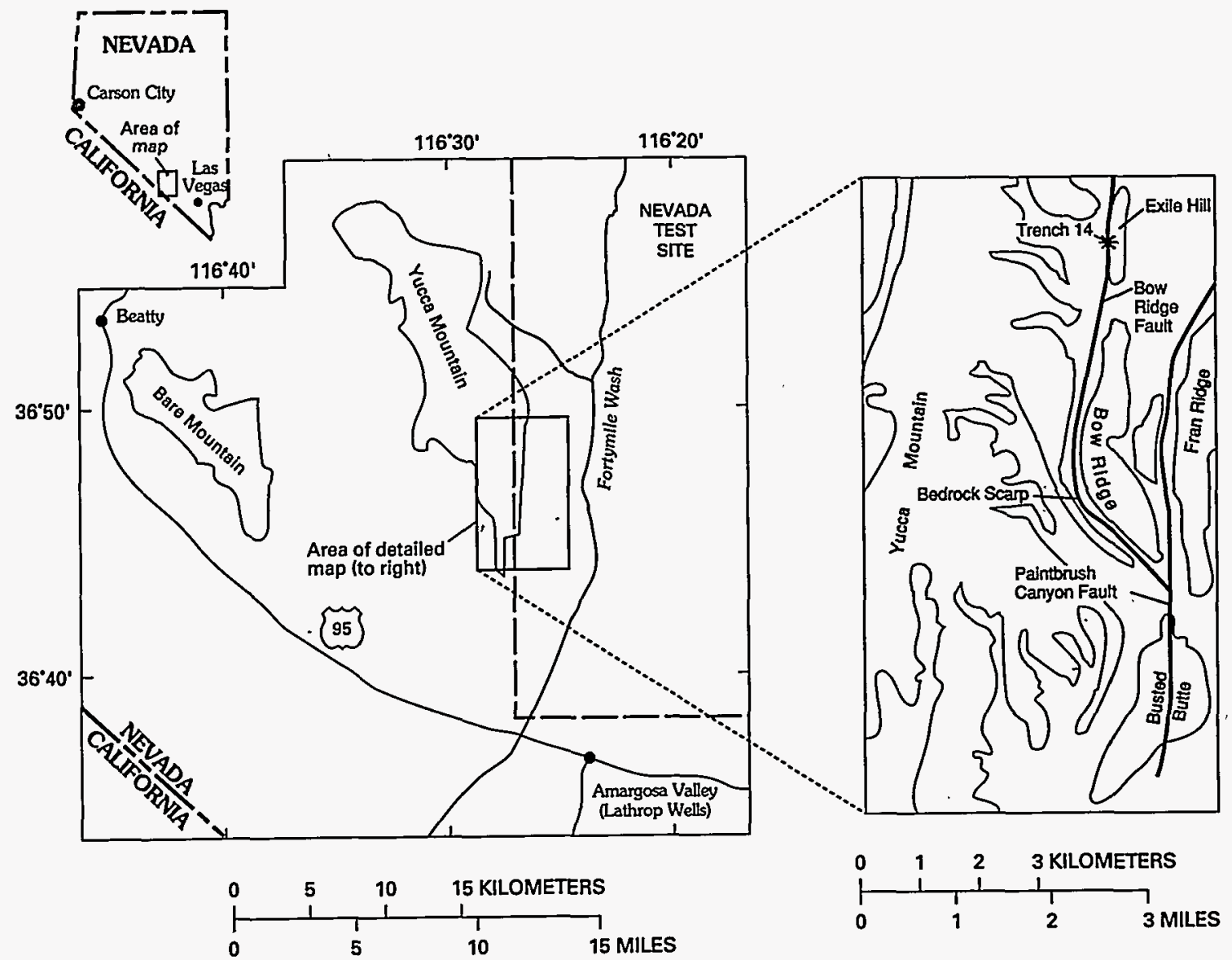

Figure 1. Map showing location of study area.

filled fractures cutting the bedrock that is exposed in trench 14 have slickensides that plunge obliquely to the southwest, indicating that fault slip included a component of left-lateral movement. However, no geomorphic evidence indicating strike-slip movement is preserved. No Quaternary scarps are present along the trace of the Bow Ridge Fault (Swadley and others, 1984). A scarp about $1 \mathrm{~m}$ high is exposed in Tertiary volcanic rocks $1.5 \mathrm{~km}$ south of Exile Hill on the west side of Bow Ridge (figs. 1 and 2). The age of the bedrock scarp has not been determined, but none of the exposed surficial deposits adjacent to the scarp show evidence of faulting.

Trench 14 is on the west side of Exile Hill at Yucca Mountain (figs. 1 and 3) and exposes the Bow Ridge Fault. Preliminary mapping of the trench was done by Swadley and others (1984). In 1984, the trench was deepened; from east to west, it exposes (1) fractured volcanic tuffs; (2) a main fault zone consisting of discrete, near-vertical veins within brecciated bedrock; and (3) colluvium and slope-wash alluvium (fig. 4, pl. 1A-F). In the spring of 1985, a second bull- dozer trench, trench $14 \mathrm{~A}$, was excavated $80 \mathrm{~m}$ to the north of trench 14 and exposes the fault in bedrock (fig. 3). Surface soils were disrupted and, in some places, removed by the excavating equipment.

In the fall of 1985, three backhoe trenches were dug. The first, trench 14B, is between trenches 14 and $14 \mathrm{~A}$ (fig. 3) and was excavated to study the soil immediately overlying the main fault zone and to study the contact between the soil and bedrock. The second and third trenches, trenches $14 \mathrm{C}$ and $14 \mathrm{D}$, are about 30 and $50 \mathrm{~m}$ south of trench 14 and were excavated to expose the main fault where it cuts alluvial units. Trench 14D exposes a growth fault inferred to have had at least three episodes of movement in about the last 500,000 years. A discussion of the structural and stratigraphic relations exposed in this trench is included in this report. All of the trenches trend approximately east-west and are perpendicular to the trace of the Bow Ridge Fault. 


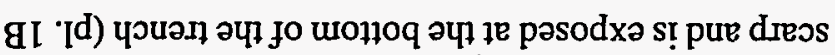

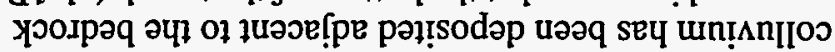

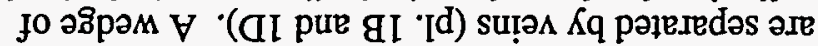

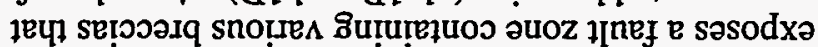

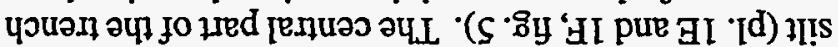

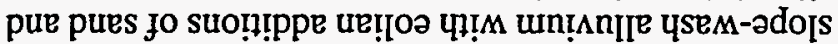

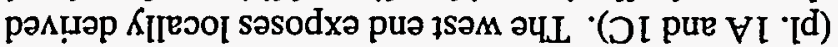

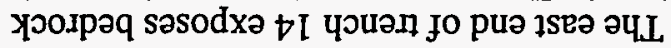

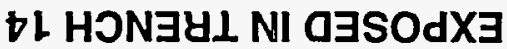

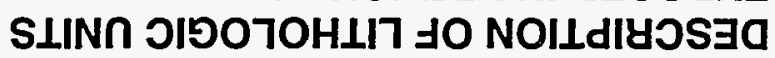

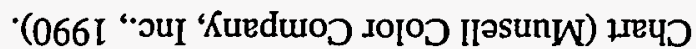

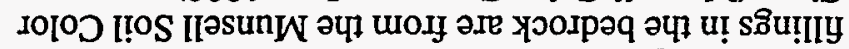

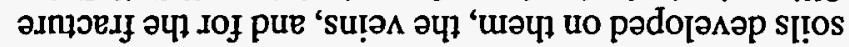

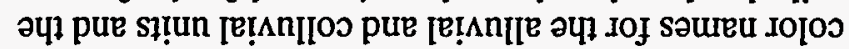

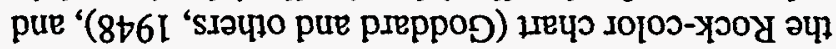

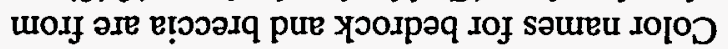

(L86I) sı

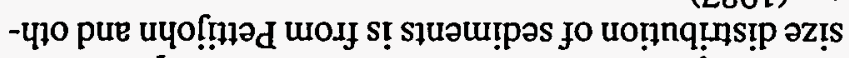

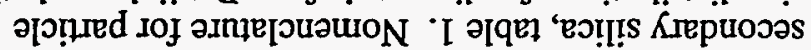

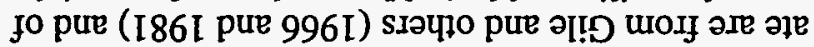

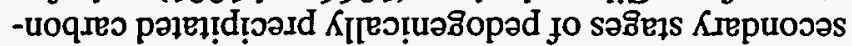

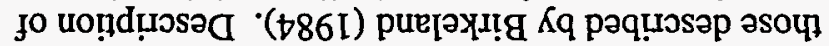
of urojuoo s!!sodəp [e!

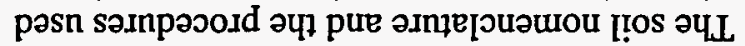

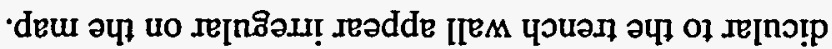

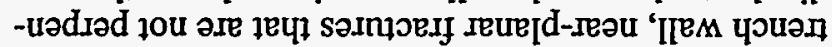
วप1 Jo K!!

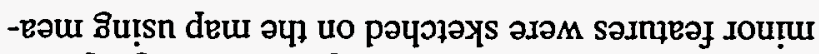

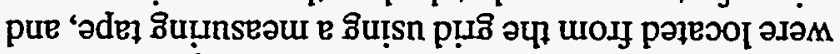
səInеว Io!̣

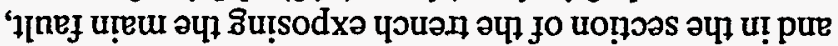

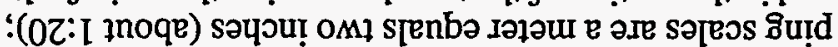

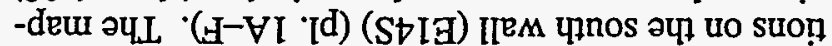

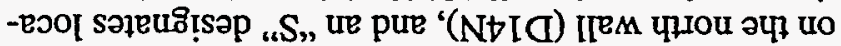
suo!̣eool səieus!!s

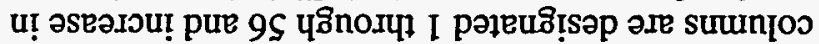

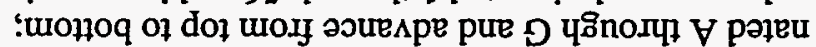

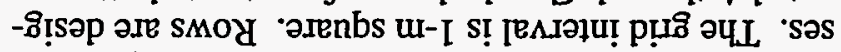

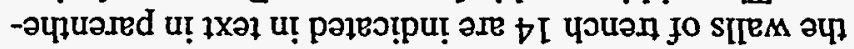

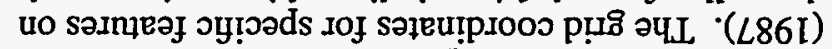

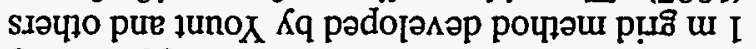

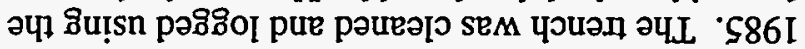

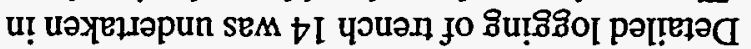

\section{Sэynaヨooyd}

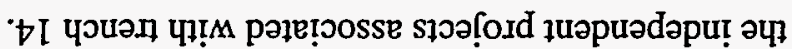

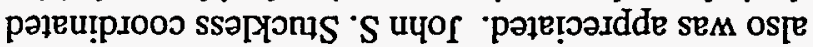

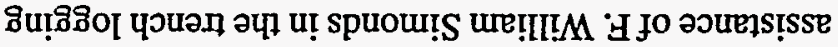

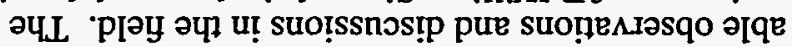

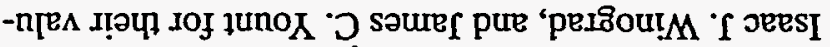

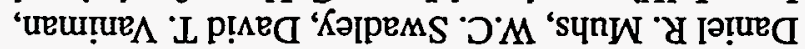

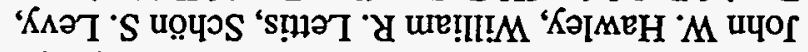

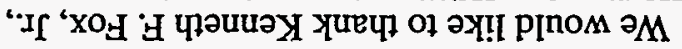

słuәшбрәрмоนхә

'วеsно uәəq әлеч

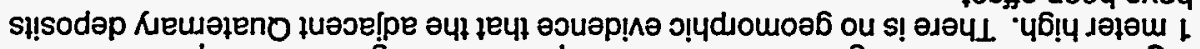

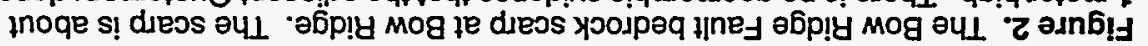

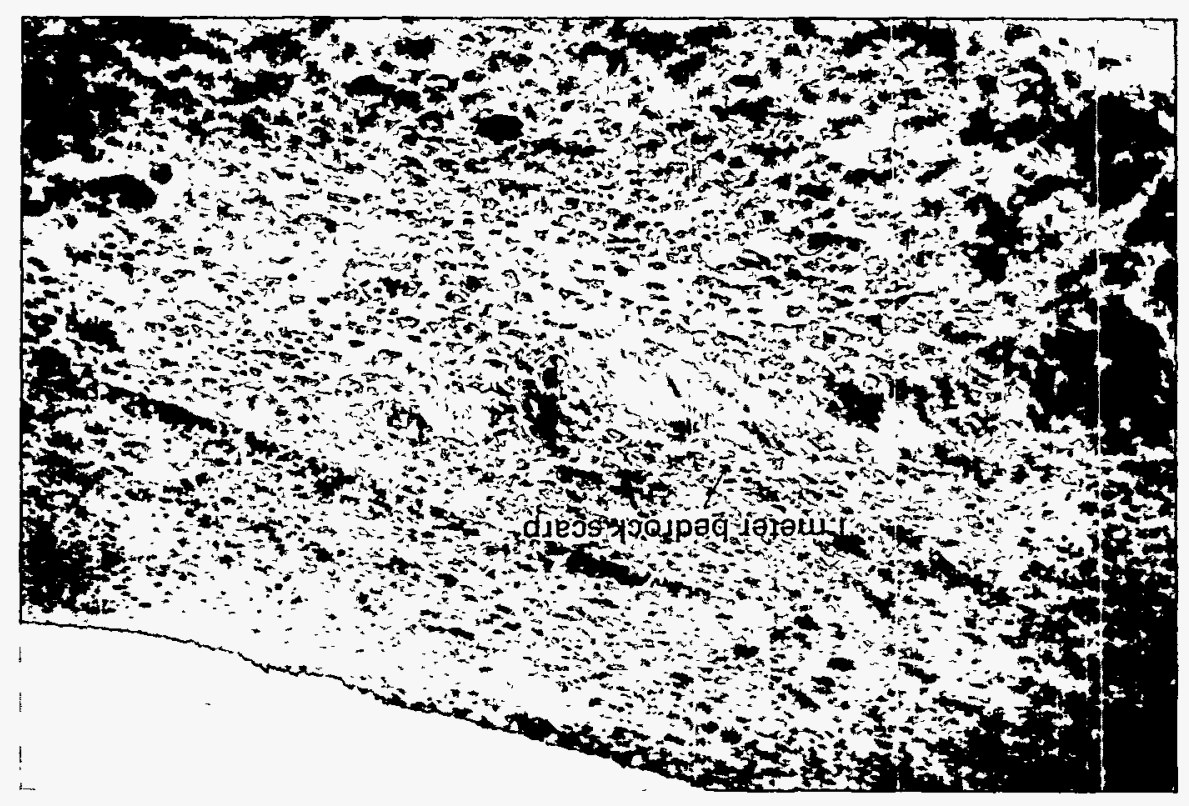




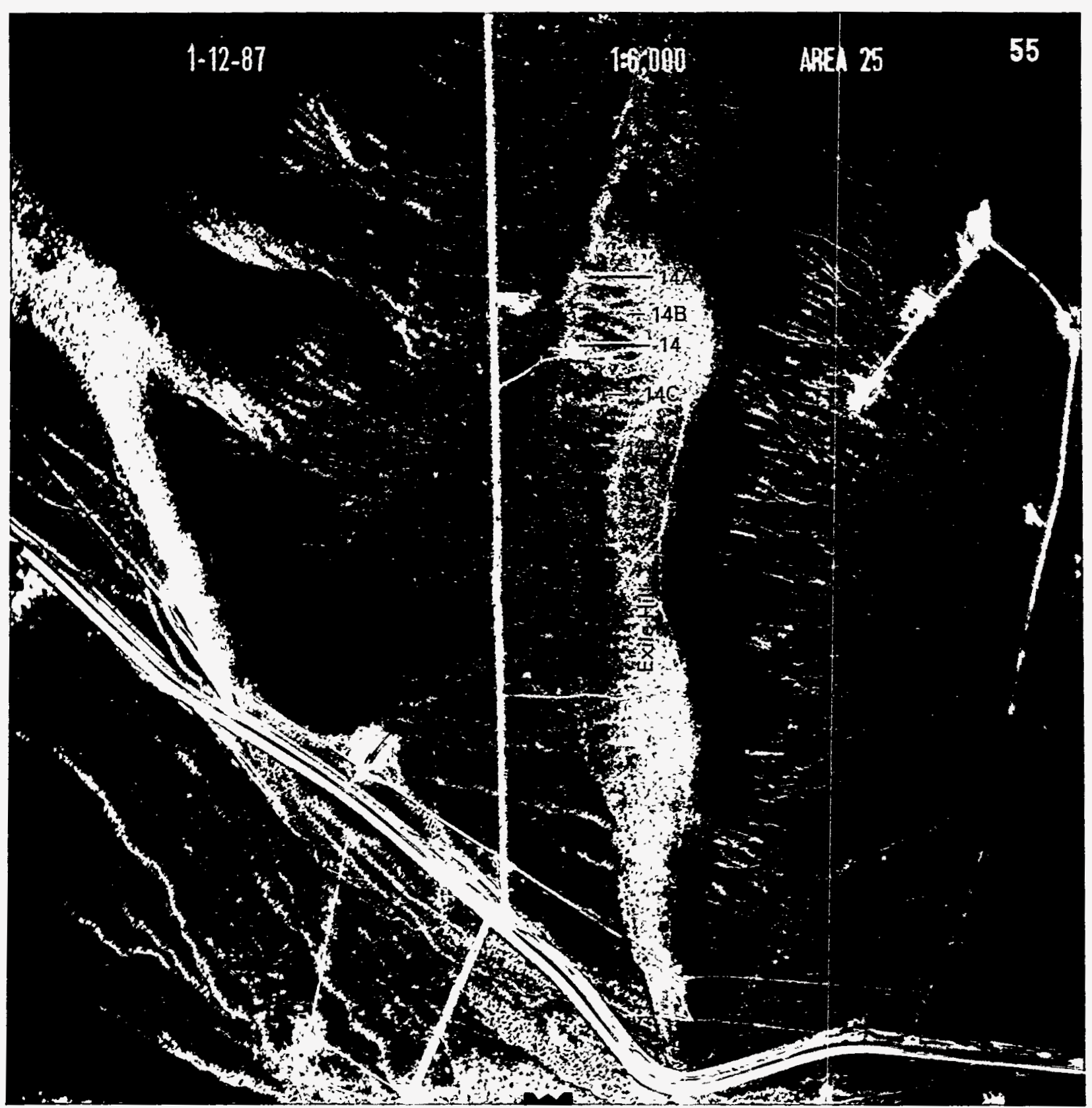

Flgure 3. Aerial photograph of Exile Hill and the locations of trenches 14, 14A, 14B, 14C, and 14D. Scale 1:6,000. 


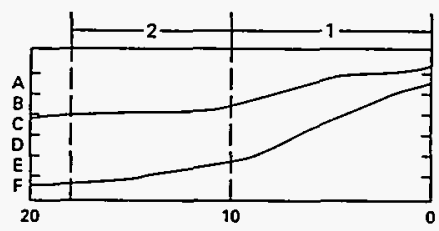

NORTH WALL, TAENCH 14
1 North wall, East end - Bedrock

2 North wall, Center section - Main fault

3 South wall, East end - Bedrock

4 South wall, Center section - Main fault

5 South wall, West of center section - Slope wash alluvium

6 South wall, West end - Slope wash alluvium

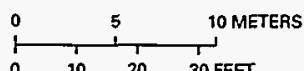

$10 \quad 20 \quad 30 \mathrm{FEET}$

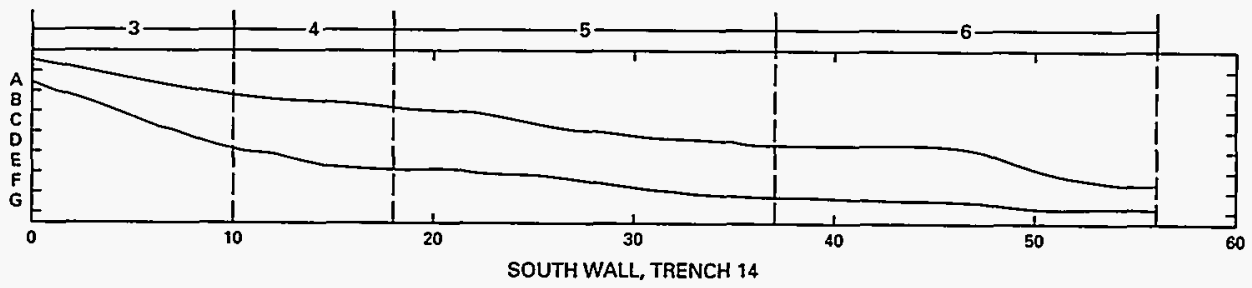

Figure 4. Index map of trench logs for use with plate 1.

Table 1. General characteristics of stages of pedogenic opaline silica development.

[Modified from Taylor, 1986; mm, millimeters]

\begin{tabular}{cl}
\hline Stage & \multicolumn{1}{c}{ Characteristics } \\
\hline 1 & White, yellow, or pinkish scale-like coatings less than \\
2 mm thick on the undersides of gravel clasts. \\
Present in soils on Holocene to late Pleistocene \\
deposits. May occur at depth on older deposits. \\
Stalactitic or pendant features $2-4$ mm long, extend- \\
ing downward from a coat on the undersides of \\
gravel clasts. Found in soils on middle Pleistocene \\
deposits. May occur at depth on older deposits. \\
Opaline silica-cemented horizon, extremely hard \\
when dry. Peds do not slake in water or a weak solu- \\
tion of hydrochloric acid (HCl). The color hues are \\
7.5 YR, probably due to clay particles in the silica \\
cement. Maximum opaline silica accumulations \\
tend to form in horizons of maximum calcium car- \\
bonate accumulation, although locally within a soil \\
profile, stage 3 may be forming above the maximum \\
calcium carbonate accumulation because the white- \\
ness of the carbonate masks the precipitated opaline \\
silica. Present in soils on middle to early Pleis- \\
tocene deposits. \\
Stage 3 morphology that has laminar, indurated opa- \\
line silica platelets which are from 4 to 20 mm thick. \\
Maximum calcium carbonate accumulation is below \\
maximum opaline silica induration. Commonly, \\
calcareous ooids are precipitated above platelets. \\
Present in soils on middle Pleistocene (rare and thin) \\
and early Pleistocene to late Pliocene deposits.
\end{tabular}

and 1D). The fault zone, characterized by prominent banded carbonate and opaline silica veins, is about $2.5 \mathrm{~m}$ wide on the center section of the north wall (fig. 6) and splays into a zone about $4 \mathrm{~m}$ wide that has

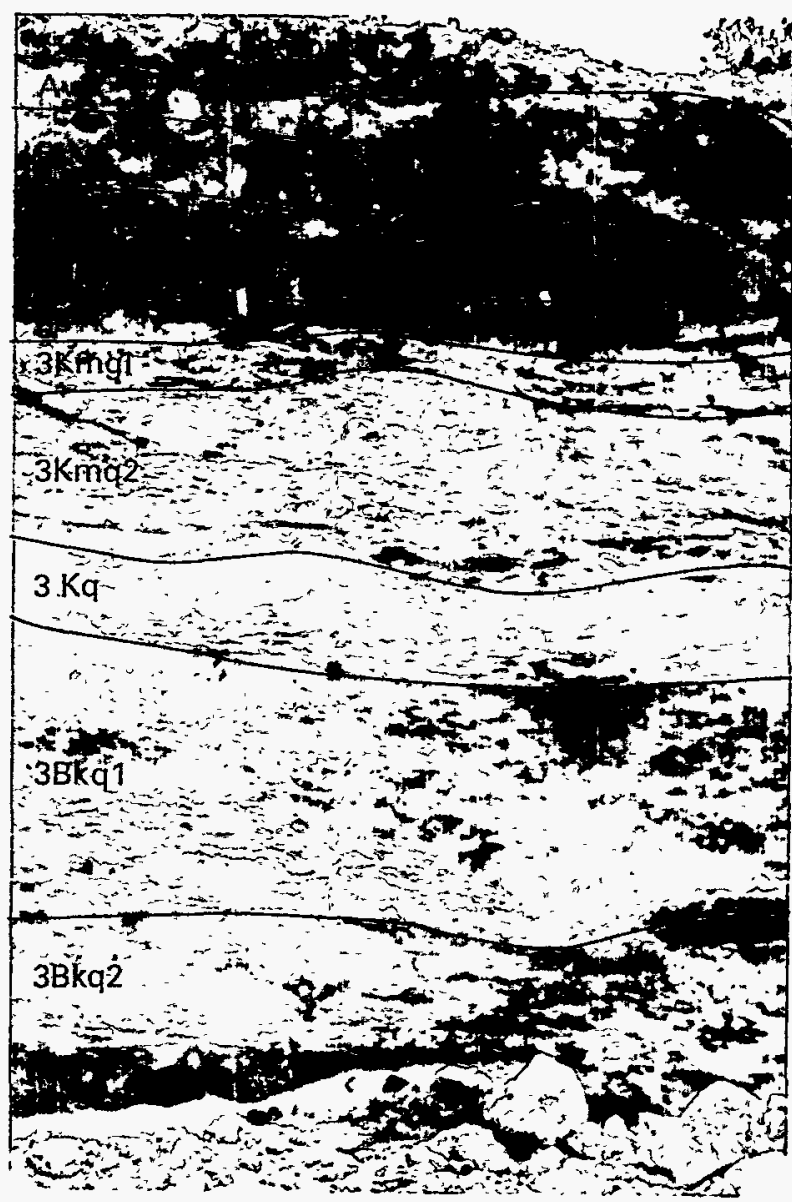

Figure 5. A characteristic section of slope-wash alluvium (pl. 1E, grid coordinate 27S). Soil horizons are labeled on the left-hand margin and marked with dark lines across the photograph. Unit 1 includes horizons $A v$ and $B t K$, Unit 2 includes horizons $2 B t j$ and $2 B+K$; and Unit 3 includes horizons $3 K m q 1,3 K m q 2,3 K q, 3 B k q 1$, and $3 B k q 2$. Units represent depositional unconformities. A near-vertical fracture can be seen in the center of the photograph. Rock hammer is 33 centimeters long. 


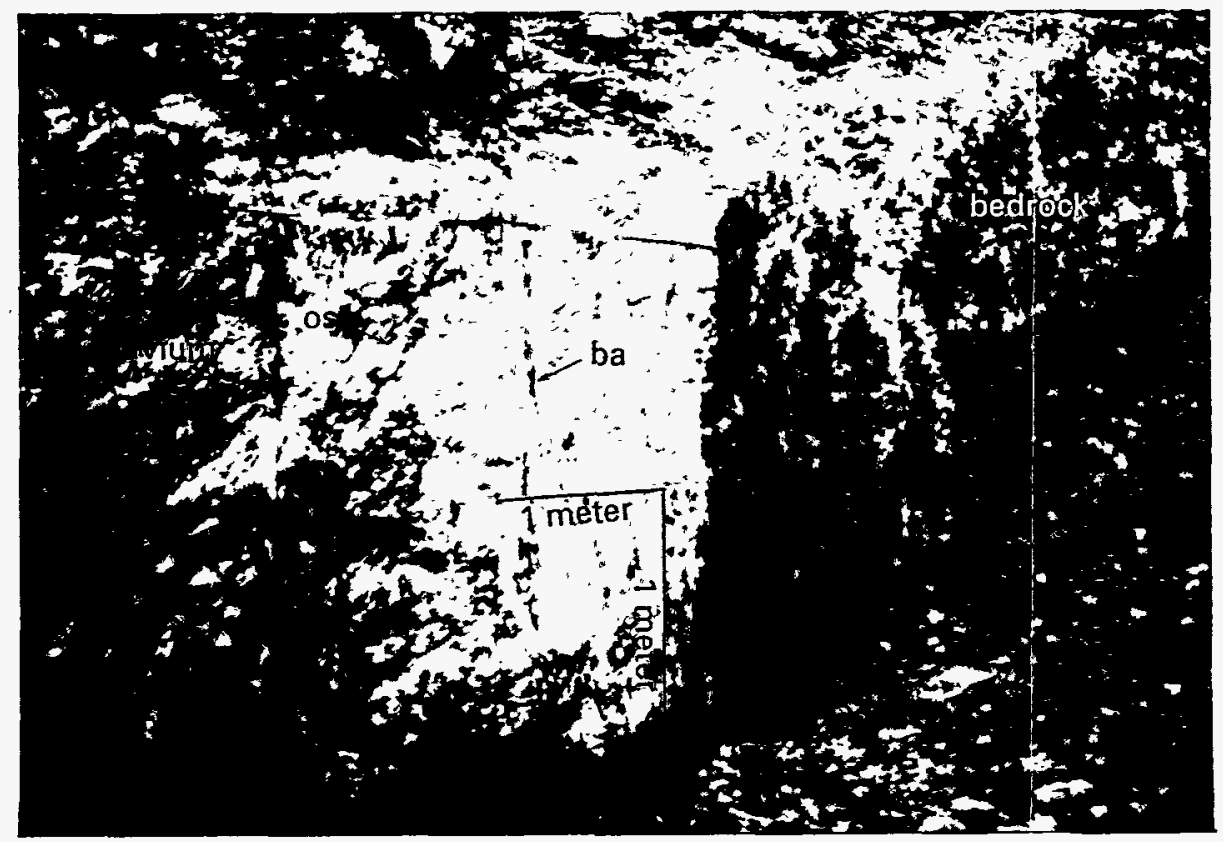

Figure 6. The main fault exposed on the north wall, center section, of trench 14. Symbols: ba, black ash and fractures filled with fine-grained sediment; os, dense opaline silica stringers. The very light-colored nonwelded tuff (NWT) is virtually indistinguishable from the adjacent slope-wash alluvium. See the center section of plate 1B for comparison.

five main veins on the center section of the south wall (fig. 7). The five main veins are designated $I-V$ from east to west on plate $1 \mathrm{D}$, and their inferred northward continuations are similarly labeled on plate $1 \mathrm{~B}$.

The units have been classified as (1) Tertiary volcanic rocks, (2) fault zone-breccia and veins, and (3) slope-wash alluvium and colluvium. Tertiary volcanic rocks, although locally highly fractured, are virtually in place; breccias consist of dislocated clasts of the Tertiary volcanic rocks.

\section{Tertiary Volcanic Rocks}

\section{Highly Fractured Nonwelded Tuff}

The highly fractured nonwelded tuff (NWT or nonwelded tuff) is a grayish-orange-pink (10R 8/2), nonwelded ash-flow tuff, stratigraphically located between the Rainier Mesa Member of the Timber Mountain Tuff [age, 11.3 Ma (Marvin and others, 1970); 11.6 Ma (Sawyer and others, 1990)] and the Tiva Canyon Member of the Paintbrush Tuff [age, 12.6 Ma (Marvin and others, 1970); 12.7 Ma (Sawyer and others, 1990)]. The nonwelded tuff is characterized by (1) white (N9), pinkish-gray (5YR 8/1), and pale-yellowish-brown (10YR 6/2) vitric pumice; (2) about 15 percent phenocrysts which are chiefly quartz and feldspar with sparse bronze biotite;

(3) about 5 percent lithic fragments of Paintbrush Tuff and Tuff of Calico Hills; and (4) granules of brown glass. The nonwelded tuff is highly fractured and the fractures are infiltrated with secondary carbonate and fine-grained sand and silt. The nonwelded tuff is exposed only on the center section of north wall (pl. 1B).

\section{Slightly Fractured Intact Tiva Canyon Member of the Paintbrush Tuff}

The slightly fractured intact Tiva Canyon Member of the Paintbrush Tuff (IT or intact Tiva Canyon Member) is a pale-red ( $5 R 6 / 2)$, devitrified, moderately to densely welded ash-flow tuff, stratigraphically from the upper lithophysal zone of the Tiva Canyon Member. The intact Tiva Canyon Member is characterized by (1) sparse, very light gray (N8) to light gray (N7) pumice which is flattened about $4: 1$ to $6: 1 ;(2)$ about 10-12 percent phenocrysts which are chiefly sanidine and plagioclase with rare biotite; (3) very rare lithic fragments; and (4) small Mn-oxide dendrites throughout the groundmass. Abundant lithophysal cavities in the intact Tiva Canyon Member, as large as $10 \mathrm{~cm}$ 


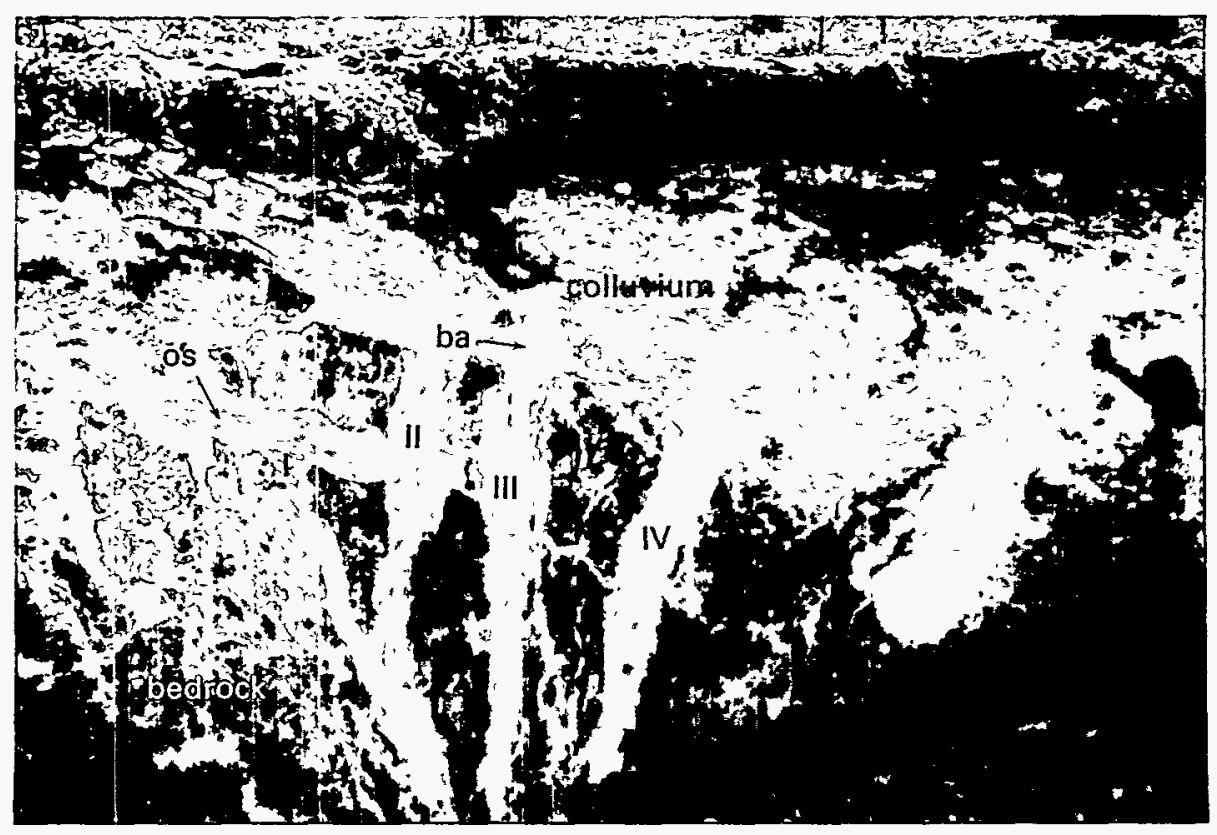

Figure 7. The main fault exposed on the south wall, center section, of trench 14. Symbols: ba, black ash and fractures filled with fine-grained sediment; os, dense opaline silica stringers. See the center section of plate 1D for comparison. Person in photograph is 160 centimeters tall.

across, are lined with vapor phase minerals, botryoidal chalcedony, and drusy quartz. The intact Tiva Canyon Member is cut by cooling joints, some of which seem to have been reactivated during faulting and brecciation (pl. 1C, bottom B7S).

\section{Highly Fractured Tiva Canyon Member of the Paintbrush Tuff}

The highly fractured Tiva Canyon Member of the Paintbrush Tuff (HFT or highly fractured Tiva Canyon Member) is also stratigraphically from the upper lithophysal zone of the Tiva Canyon Member. The highly fractured Tiva Canyon Member differs from the intact Tiva Canyon Member only because it is highly fractured, but does not seem to be penetratively sheared. Fracture spacing is about $1-10 \mathrm{~cm}$ and most fractures are vertical and divide the tuff into long, angular fragments or blocks. Lithophysae and pumice are not offset. The highly fractured Tiva Canyon Member is characterized by containing (1) drusy quartz which commonly lines lithophysal cavities; (2) botryoidal quartz which locally coats fractures (pl. 1C, C9SC10S); and (3) small amounts of secondary microcrystalline carbonate and opaline silica in fractures. Highly fractured Tiva Canyon Member grades laterally into intact Tiva Canyon Member, carbonate-cemented and fractured Tiva Canyon Member, and densely carbonate-cemented and fractured Tiva Canyon Member (described in the next sections). The abundance of secondary carbonate decreases with depth in the bedrock and in the adjacent slope-wash alluvium.

\section{Carbonate-Cemented and Fractured Tiva Canyon Member of the Paintbrush Tuff}

The carbonate-cemented and fractured Tiva Canyon Member of the Paintbrush Tuff (CCT or carbonatecemented Tiva Canyon Member) is similar to the highly fractured Tiva Canyon Member except the carbonate-cemented Tiva Canyon Member is cut by fractures containing infiltrated sand and silt, with secondary carbonate and opaline silica. The secondary carbonate is white (10YR $8 / 0$, dry; 10YR $8 / 3$, moist) and decreases in abundance with depth. Near the surface, the fine-grained matrix is pinkish-white (7.5YR $8 / 2$, dry; $7.5 Y R$ 7/4, moist) and, in texture and structure, resembles a $B$ soil horizon, containing opaline silica and clay, that has been engulfed by carbonate. Carbonate that fills the fractures is powdery, whereas carbonate that coats individual clasts is dense and smooth (stages II and III). Some of the opaline silica that fills interstices between rock fragments may have replaced the earlier secondary carbonate. Fracture 
spacing is about 7-20 cm, and the ash-flow tuff is broken into angular to subrounded blocks. About 50 percent of the fractures are carbonate-filled; and locally, the blocks of bedrock are partly matrix supported. Carbonate-cemented Tiva Canyon Member grades into densely carbonate-cemented and fractured Tiva Canyon Member and generally overlies and grades downward to highly fractured Tiva Canyon Member.

\section{Densely Carbonate-Cemented and Fractured Tiva Canyon Member of the Paintbrush Tuff}

The densely carbonate-cemented and fractured Tiva Canyon Member of the Paintbrush Tuff (DCT or densely carbonate-cemented Tiva Canyon Member) is similar to carbonate-cemented Tiva Canyon Member except that rock fragments are supported by an almost continuous matrix of secondary carbonate. Finegrained sediments infiltrate all of the fractures in the densely carbonate-cemented Tiva Canyon Member, and it is probably formed through weathering of the highly fractured Tiva Canyon Member.

\section{Fault Zone-Breccia and Veins}

\section{Nonwelded Tuff Fault Breccia}

The nonwelded tuff fault breccia (NWB or nonwelded tuff breccia) is grayish-orange-pink (10R 8/2), contain angular clasts $(0.5-2 \mathrm{~cm})$ of nonwelded tuff, and is within the main fault zone. The nonwelded breccia is formed from the nonwelded tuff. The nonwelded breccia contains fragments of silicified tuff and broken opaline silica vein material. Fragments within the nonwelded breccia are supported by a matrix of rock powder and secondary carbonate. In places, the nonwelded breccia is moderately indurated by secondary carbonate. Where the nonwelded breccia is in contact with the veins, the contact is gradational. The nonwelded breccia is commonly in abrupt contact with opaline silica laminae. Stringers of carbonate are present within this unit. Nonwelded tuff breccia is only exposed on the center section of the north wall (pl. 1B, 14N).

\section{Uncemented Tiva Canyon Member Fault Breccia}

The uncemented Tiva Canyon Member fault breccia (UFB or uncemented fault breccia) is light-gray (N7) to light-brownish-gray (5YR 6/1) and consists of fragments of slightly fractured intact Tiva Canyon Member with little matrix cement. Clasts range from silt-sized rock powder to angular fragments that are from 5 to $10 \mathrm{~cm}$ across. Where coarse-grained, the uncemented fault breccia is loose, and voids are lined with drusy and botryoidal quartz. Where fine-grained, this unit is moderately indurated and silicified in places, especially where it is in contact with other units. The fine-grained uncemented fault breccia is probably a noncemented variant of the cemented cataclastic fault breccia (described in a following section). The uncemented fault breccia locally grades upward into the silica-cemented Tiva Canyon Member fault breccia (described in the next section) indicating that silicification is a near-surface process. The uncemented fault breccia contains a few fractures filled with black ash (pl. 1D, E15S).

\section{Silica-Cemented Tiva Canyon Member Fault Breccia}

The silica-cemented Tiva Canyon Member fault breccia (SFB or silica-cemented fault breccia) consists of angular to subrounded clasts of welded tuff, many of which are intact Tiva Canyon Member, supported by a grayish-orange (10YR 7/4) to pale-yellowish-brown (10YR 6/2) opaline silica matrix. Clasts range in size from 0.1 to $12 \mathrm{~cm}$. The matrix is almost the same color (2.5YR 7/2) as the secondary opaline silica that forms laminar plates in the slope-wash alluvium and dense stringers in the veins. The matrix cement in the silicacemented fault breccia contains microcrystalline calcite as well as opaline silica. Most clasts smaller than $10 \mathrm{~cm}$ appear to be silicified. The silica-cemented fault breccia is extremely hard, and fractures through rock fragments, although, some areas of softer carbonatecemented breccia may be included with the silicacemented fault breccia (pl. 1A, B7N, D7N). In places, botryoidal quartz is present as a coating on the silicacemented fault breccia (silica-coated fracture faces, pl. 1D, D13S, D16S). The silica-cemented fault breccia grades laterally to cemented cataclastic fault breccia (described in the next section).

\section{Cemented Cataclastic Fault Breccia}

The cemented cataclastic fault breccia (CB or cataclastic breccia) is a grayish-red (10R 4/2) and grayish-red-purple (5RP 4/2). Toward the edges of some of the exposures, the cataclastic breccia is light gray and grades to medium gray (N5) to medium dark gray (N4) where in contact with vein material (pl. 1D, E14S, D14S). The cataclastic breccia is densely silicified and hard, although opaline silica is not distinguishable in hand samples as a visible matrix. Commonly, the silicification grades from well cemented where the cataclastic breccia is in contact with the veins, to less cemented between the veins toward the center of the 
exposure (pl. 1D, D14S, E14S). The unit grades laterally into and includes some silica-cemented fault breccia.

The cataclastic breccia was probably formed by recementing ground up tuff. Many of the rock fragments in the cataclastic breccia are from the intact Tiva Canyon Member. Pumice and lithophysae are not preserved, except in a few intact clasts of the Tiva Canyon Member caprock (pl. 1D, D15S), a unit that is not exposed in trench 14. The clasts of Tiva Canyon Member caprock are light-brownish-gray (5YR 6/1) with common white and medium light gray (N6) pumice that is flattened about $5: 1$. There are fewer pumice in the Tiva Canyon Member caprock than in the intact Tiva Canyon Member. The lithophysae in the Tiva Canyon Member caprock are also less abundant and much more flattened than in the intact. The caprock contains 16-20 percent phenocrysts which are primarily sanidine and bronze biotite.

\section{Vein Filling}

Vein filling (VF) consists of irregularly alternating cemented laminae and vertically to almost horizontally oriented stringers that consist of (1) hard, white (10YR 8/0, dry and moist) carbonate; (2) chalky, white (10YR 8/0, dry and moist) carbonate; (3) light gray (10YR 7/2, dry) to very pale brown (10YR 7/3 moist) opaline silica; and (4) weakly cemented white (10YR $8 / 2$, dry) to light gray (10YR 7/2, moist) sand (fig. 8). The veins contain less than 5 percent gravel which is primarily clasts of intact Tiva Canyon Member that has some reworked vein material. Dry consistency varies from extremely hard to loose. Laminae are typically not paired; they do not match in composition or correspond with laminae on either side of the medial zone of the vein(s). Laminae vary in thickness from 0.2 to $10 \mathrm{~cm}$ and are not continuous features for more than 20 to $30 \mathrm{~cm}$. Contacts between carbonate and opaline silica stringers are abrupt. Where opaline silica laminae are adjacent to a breccia unit, the contacts tend to be gradational between the veins and breccia (pl. 1B, D14N, E14N). Dense opaline silica stringers are most abundant near the center of veins and near contacts with breccia (fig. 9). The maximally carbonatecemented soil horizons $(3 \mathrm{Kmq})$ within unit 3 (described in the slope-wash alluvium section), drape the bedrock and tend to merge with the veins (pl. 1D, bottom right of B13S, top right of C14S).

Magnetic black ash (Andrei Sarna-Wojcicki, U.S. Geological Survey, oral commun., 1986) loosely fills some fractures (fig. 8). Ash-filled fractures tend to be near the center of vertically oriented veins (pl. 1D, veins III and IV); however, the ash-filled fractures also may be adjacent to the surrounding bedrock (pl. 1D, $15 \mathrm{~S}$, vein IV). Fractures containing ash crosscut all other laminae in the veins and the maximally developed $K$ horizons within unit 3. In a few places the ashfilled fractures are cut by a younger lower angle sandy or carbonate-filled vein, or both. Although the ash usually occurs in discrete fractures, in the upper right section of C15S on plate 1D, the black ash is disseminated throughout a pod of ooidic carbonate that is connected to the top of unit 3 by a fracture surrounded by disseminated ash. The shape of the pod indicates it may be a very old, filled animal burrow.

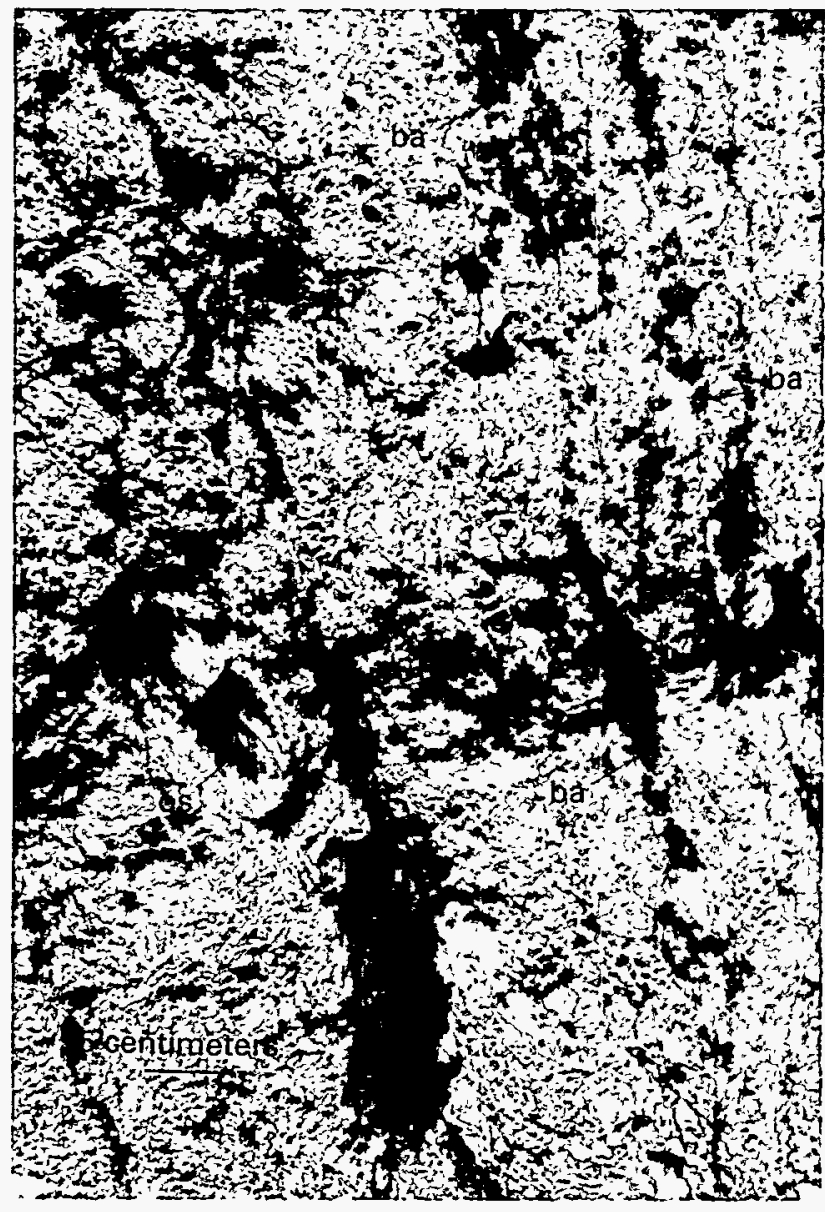

Figure 8. A typical vein exposed in trench 14. Photograph is taken of the north wall. Symbols: ba, black ash and fractures filled with fine-grained sediment; os, dense opaline silica stringers.

This ash correlates in age with basalt from one of the Crater Flat cones or from the Lathrop Wells cone. The Crater Flat and Lathrop Wells ashes are geochemically indistinguishable (Andrei Sarna-Wojcicki, oral commun., 1986). The Crater Flat cones are $13 \mathrm{~km}$ west of Exile Hill and are K-Ar dated at 1.1 and $1.3 \mathrm{Ma}$ (Crowe and Carr, 1980). The Lathrop Wells cone is 


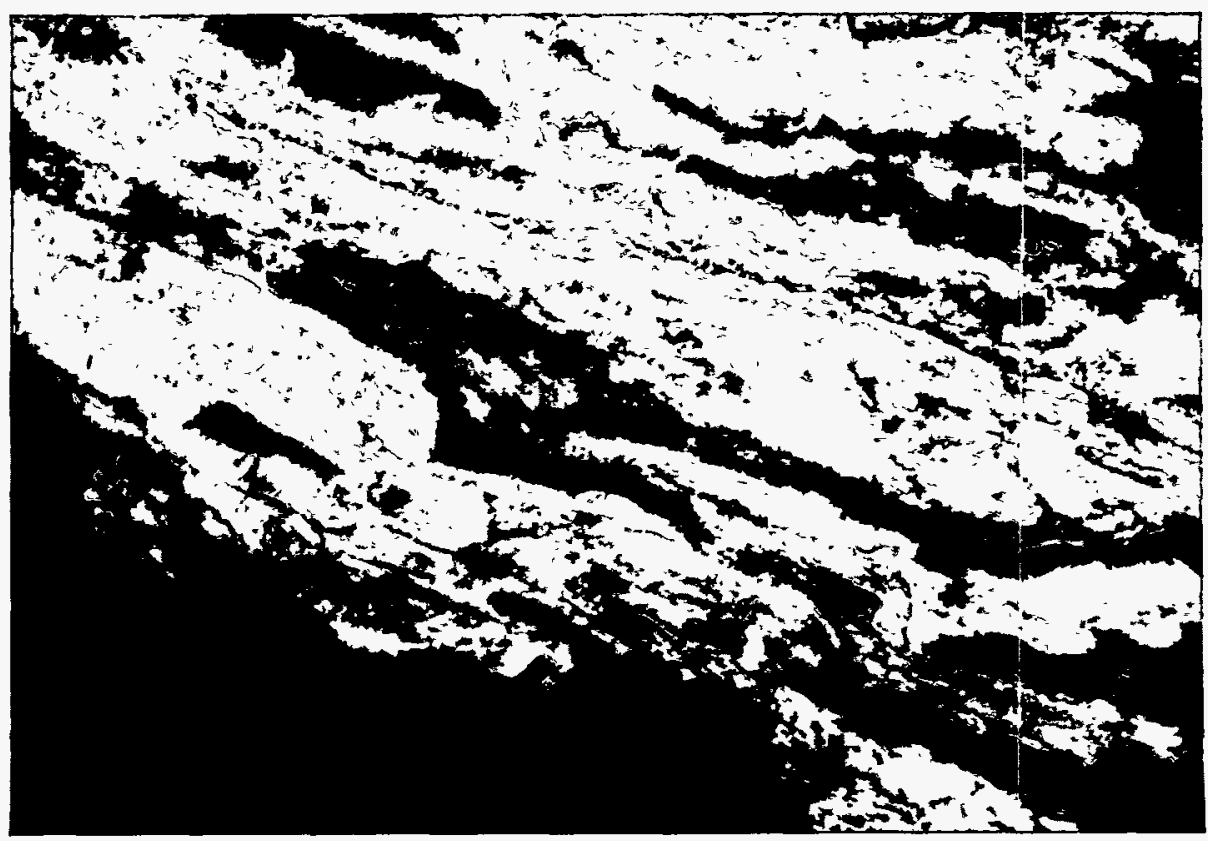

Figure 9. Dense opaline stringers exposed on the south wall of trench 14. Opaline stringers are exposed on the north wall and are shown in figure 7. The opaline stringer adjacent to the lens cap grades into the breccia cement. Symbols: os, dense opaline silica stringer. Lens cap is 5 centimeters in diameter.

$16 \mathrm{~km}$ southwest of Exile Hill and is dated by (1) $\mathrm{K}-\mathrm{Ar}$ at $138 \pm 8 \mathrm{ka}$ and $141 \mathrm{ka}$ (Turrin and others, 1991), and (2) thermoluminescence at $30 \mathrm{ka}$ (B.M. Crowe, LANL, oral commun., 1990). Geomorphic, pedogenic, and stratigraphic evidence have recently been interpreted as indicating a much younger age for the Lathrop Wells cone, perhaps as young as 15-20 ka (Wells and others, 1990). One possible source of error is that the basalt flows, used in $\mathrm{K}-\mathrm{Ar}$ dating and associated with the cinder cones, are not contemporaneous with the ash eruptions that form the cones.

\section{Slope-Wash Alluvium and Colluvium}

\section{Slope-Wash Alluvium}

In trench 14 , locally derived, sandy slope-wash alluvium is downfaulted against volcanic bedrock of Miocene age along a near-vertical fault zone. This unit was originally described by Swadley and others (1984) as a fluvial sand sheet (Q2s). The slope-wash alluvium contains from 5 to 25 percent gravel. The nearest and, therefore, most likely source of the boulders is the bedrock slope of Exile Hill, east of trench 14. Alternatively, the boulders may have been transported northward to their present position during building of the northern salient of the fan at the mouth of Drill Hole Wash, $1.5 \mathrm{~km}$ to the southwest. A soil profile within the slope-wash alluvium was described, sampled, and analyzed in detail (pl. 1E, 27S) (fig. 5, tables 2 and 3).

The slope-wash alluvium and vein fillings have been dated by the uranium-trend (U-trend) method (Swadley and others, 1984; Rosholt and others, 1985), and by the uranium-series (U-series) method (Stuckless and others, 1991) (table 4). The U-trend method can be used on deposits that have ages between 5,000 and 700,000 years, but is most accurate in the range of 60,000 to 600,000 years (Muhs and others, 1990). The U-series method can be used on deposits that have ages between 1,000 and 360,000 years (Rosholt and others, 1991), and sometimes on deposits as old as 400,000 years, depending on the initial uranium ratio (D.R. Muhs, U.S. Geological Survey, oral commun., 1990). Relative errors for both methods are large near the lower and upper limits of the age range of the method.

Three distinct lithologic units are present in the slope-wash alluvium - units 1,2 , and 3 (table 2, fig. 5, pl. 1B-1F). The slope-wash alluvium has been divided into nine soil horizons based on the morphology of secondary carbonate and opaline silica (table 2), and the amount of secondary clay (table 3 ). Soil formed in the slope-wash alluvium is characterized by a welldeveloped $K$ horizon (stage III and IV) that is cemented 
Table 2. Field description of a characteristic soil exposed in the slope-wash alluvium in trench 14

[Units and soil horizons are shown on plates IE and IF and figure 5. Horizon boundaries (HZN BND)-as, abrupt smooth; aw, abrupt wavy; cw, clear wavy; and dashes, no data. Textual classes (based on grain size analyses_-SL, sandy loam; LS, loamy sand. Structure - (1) Grade -2, moderate; 3, strong; $m$, massive; $m$-sg, massive to single; (2) Strength - m, medium; co, coarse; vco, very coarse; and

(3) Kind-sbk, subangular blocky; pr, prismatic; pl, platy; abk, angular blocky. Dry consistence-so soft; sh, slightly hard; h, hard; eh, extremely hard. Wet consistence-so, nonsticky; ss, slightly sticky;

s, sticky; po, nonplastic; ps, slightly plastic. $\mathrm{CaCO}_{3}$ matrix —e, slightly effervescent; es, strongly effervescent; ev, violently effervescent; $\mathrm{cm}$, centimeters; \%, percent; <, less than; dashes (-), no data]

\begin{tabular}{|c|c|c|c|c|c|c|c|c|c|c|c|c|c|}
\hline \multirow{2}{*}{$\begin{array}{c}\text { Soll } \\
\text { horl- } \\
\text { zon }\end{array}$} & \multicolumn{2}{|c|}{$\begin{array}{l}\text { Depth } \\
\text { (cm) }\end{array}$} & \multirow{2}{*}{$\begin{array}{l}\text { HZN } \\
\text { BND }\end{array}$} & \multicolumn{2}{|c|}{ Color ${ }^{1}$} & \multirow{2}{*}{$\begin{array}{l}\text { Tex- } \\
\text { ture }\end{array}$} & \multirow{2}{*}{ Structure } & \multicolumn{2}{|c|}{ Consistence } & \multicolumn{2}{|c|}{$\mathrm{CaCO}_{3}{ }^{2}$} & \multirow{2}{*}{$\begin{array}{c}\text { Percent } \\
\text { gravel } \\
\text { volume }\end{array}$} & \multirow{2}{*}{$\mathrm{SiO}_{2}^{3}$} \\
\hline & Top & Base & & Dry & Molst & & & Dry & Wet & Matrix & Stage & & \\
\hline \multicolumn{14}{|c|}{ Unit $1^{4}$} \\
\hline Av & 0 & 9 & as & 10YR $6 / 3$ & 10YR $4 / 3$ & SL & 3 co sbk & so & ss, ps & 0 & 0 & 10 & 0 \\
\hline Btk & 9 & 20 & aw & $10 Y R 6 / 3$ & 10YR $4 / 3$ & SL & 2 co sbk & so & sst, ps & es & 1 & 25 & 0 \\
\hline \multicolumn{14}{|c|}{ Unit $2^{5}$} \\
\hline $2 B t j$ & 20 & 50 & cw & 10YR 5.5/5/4 & 10YR $3.5 / 4$ & SL & $\begin{array}{l}2-3 \text { m-co pr } \\
2 \text { co sbk }\end{array}$ & h & $\mathrm{s}, \mathrm{ps}$ & e-es & I & 5 & 0 \\
\hline $2 B+K$ & 50 & 61 & as & 10YR 6/3.5 & 10YR 6/3.5 & SL & $2 \mathrm{~m} \mathrm{sbk}$ & $\mathrm{sh}$ & ss, ps & $\mathrm{es}, \mathrm{ev}$ in $\mathrm{K}$ & $5-20$ & 0 & \\
\hline \multicolumn{14}{|c|}{ Unit $3^{6}$} \\
\hline 3Kmq1 & 61 & 77 & aw & $10 \mathrm{YR} 8 / 0$ & $10 \mathrm{YR} 8 / 2$ & LS & 3 vco pl & eh & so, po & ev & IV & 5 & 4 \\
\hline $3 \mathrm{Kmq} 2$ & 77 & 119 & as & 10YR $8 / 2$ & $10 \mathrm{YR} 8 / 3$ & LS & $3 \mathrm{vcopl}, \mathrm{m}$ & eh & so, po & ev & IV, $50 \%$ ooids & 10 & $\begin{array}{l}4(<5 \mathrm{~mm}) \\
10 \mathrm{YR} 7 / 3 \text { (dry), } \\
\text { 10YR 7/4 } \\
\text { (moist) }\end{array}$ \\
\hline $3 \mathrm{Kq}$ & 119 & 138 & as & $10 Y R 8 / 0$ & 10YR $8 / 2$ & SL & $\mathrm{m}$ & eh & so, po & ev & III & 5 & 3,4 in places \\
\hline $3 B \mathrm{kq} 1$ & 138 & 202 & aw & 10YR $8 / 2$ & 10YR $5 / 3$ & LS & $\begin{array}{c}2 \text { co abk, } \\
\text { m-sg }\end{array}$ & so & so, po & ev & $\begin{array}{l}\text { II dense, III lenses, } \\
\text { ooid lenses }\end{array}$ & 25 & $2,3-4$ in places \\
\hline 3Bkq2 & 202 & 247 & - & $10 \mathrm{YR} 7.5 / 2$ & 10YR 5/3 & LS & m-sg & so & so, po & ev & $\begin{array}{l}\text { II, III lenses, } \\
\text { ooid lenses }\end{array}$ & 10 & $2-3$ \\
\hline
\end{tabular}

'Colors are from the Munsell soil color charts (1990).

${ }^{2} \mathrm{CaCO}_{3}$ stages from Gile and others (1966).

${ }^{3} \mathrm{SiO}_{2}$ stages from table 1 .

${ }^{4}$ Parent material is slope-wash alluvium and fine-grained eolian sand and silt.

${ }^{5}$ Parent material is slope-wash alluvium with 5 percent $\mathrm{K}$ plates derived from Unit 3.

${ }^{6}$ Parent material is fine-grained slope-wash alluvium. 
Table 3. Selected grain-size data, bulk density, and calcium carbonate content from a characteristic soil exposed in the slope-wash alluvium in trench 14

[Units and soil horizons are shown on plates $1 \mathrm{E}$ and $\mathrm{IF}$ and figure 5. Values for sand, silt, and clay are based on sieve and pipette analyses. Particle-size limits-sand 2-0.05 millimeters; silt, 0.050.002 millimeter, clay, less than $0.002 \mathrm{~mm}$. Textural classes—vco, very coarse; co, coarse; med, medium; fi, fine; vfi, very fine; cm, centimeter, gm/ $\mathrm{cm}^{3}$, grams per centimeter cubed; NA, not applicable]

\begin{tabular}{|c|c|c|c|c|c|c|c|c|c|c|c|c|c|c|c|c|c|}
\hline \multirow{2}{*}{$\begin{array}{c}\text { Soll } \\
\text { horizon }\end{array}$} & \multicolumn{2}{|c|}{$\begin{array}{l}\text { Depth } \\
\text { (cm) }\end{array}$} & \multicolumn{5}{|c|}{ Percent sand } & \multicolumn{3}{|c|}{ Percent silt } & \multicolumn{2}{|c|}{ Percent clay } & \multicolumn{3}{|c|}{$\begin{array}{c}\text { Total } \\
\text { (percent) }\end{array}$} & \multirow{2}{*}{$\begin{array}{c}\text { Density } \\
\left\langle\left(\mathrm{gm} / \mathrm{cm}^{3}\right\rangle\right.\end{array}$} & \multirow{2}{*}{$\begin{array}{c}\mathrm{CaCO}_{3} \\
\text { (percent) }\end{array}$} \\
\hline & Top & Baso & veo & co & med & fi & vfl & co & $m+f l$ & vfl & $\mathrm{CO}+\mathrm{m}$ & fI & Sand & Silt & Clay & & \\
\hline \multicolumn{18}{|c|}{ Unit 1} \\
\hline Av & 0 & 9 & 2.45 & 2.94 & 6.09 & 42.45 & 18.85 & 5.77 & 8.84 & 5.41 & 4.51 & 2.71 & 72.77 & 20.01 & 7.21 & 1.63 & 0.46 \\
\hline Btk & 9 & 20 & 2.34 & 2.45 & 4.90 & 33.71 & 19.99 & 9.56 & 9.56 & 4.78 & 8.64 & 4.05 & 63.40 & 23.91 & 12.69 & 1.69 & 1.22 \\
\hline \multicolumn{18}{|c|}{ Unit 2} \\
\hline $2 B t j$ & 20 & 50 & 1.54 & 1.96 & 5.45 & 38.08 & 17.74 & 8.40 & 11.80 & 5.54 & 6.79 & 2.68 & 64.77 & 25.75 & 9.48 & 1.67 & 0.34 \\
\hline $2 \mathrm{~B}+\mathrm{K}(\mathrm{B})$ & 50 & 61 & 1.75 & 2.07 & 5.84 & 39.99 & 17.65 & 8.08 & 11.32 & 4.49 & 5.92 & 2.87 & 67.32 & 23.89 & 8.80 & 1.65 & 2.37 \\
\hline $2 \mathrm{~B}+\mathrm{K}(\mathrm{K})$ & 50 & 61 & 28.13 & 15.71 & 11.35 & 16.92 & 6.72 & 3.85 & 4.92 & 3.42 & 4.49 & 4.49 & 78.82 & 12.20 & 8.98 & 1.34 & 33.05 \\
\hline \multicolumn{18}{|c|}{ Unit 3} \\
\hline $3 \mathrm{Kmql}$ & 61 & 77 & 13.21 & 10.41 & 11.57 & 32.69 & 9.92 & 4.11 & 6.99 & 3.29 & 3.91 & 3.91 & 77.80 & 14.38 & 7.81 & 1.62 & 40.12 \\
\hline $3 \mathrm{Kmq} 2$ & 77 & 119 & 13.76 & 12.03 & 14.51 & 32.67 & 9.67 & 4.18 & 5.23 & 3.14 & 0.63 & 4.18 & 82.63 & 12.56 & 4.82 & 1.66 & 45.92 \\
\hline $3 \mathrm{Kq}$ & 119 & 138 & 12.46 & 11.78 & 14.96 & 28.10 & 9.14 & 4.35 & 7.09 & 3.66 & 2.74 & 5.72 & 76.45 & 15.09 & 8.46 & 1.46 & 56.14 \\
\hline 3Bkq1 & 138 & 202 & 4.66 & 4.24 & 9.44 & 44.87 & 16.01 & 5.85 & 5.85 & 2.42 & 3.63 & 3.03 & 79.22 & 14.12 & 6.66 & 1.73 & 26.81 \\
\hline 3Bkq2 & 202 & 247 & 6.37 & 4.86 & 7.94 & 49.02 & 14.14 & 3.64 & 5.47 & 2.55 & 4.01 & 2.00 & 82.32 & 11.67 & 6.01 & 1.55 & 23.56 \\
\hline \multicolumn{18}{|c|}{ Calcium carbonate fracture fill from bedrock } \\
\hline NA & NA & NA & 26.88 & 16.55 & 11.59 & 12.77 & 7.73 & 4.26 & 8.25 & 2.92 & 1.33 & 7.72 & 75.52 & 15.43 & 9.05 & NA & 69.41 \\
\hline \multicolumn{18}{|c|}{ Material from vein III containing basaltic ash (D155) ${ }^{1}$} \\
\hline NA & NA & NA & 2.60 & 3.99 & 11.89 & 60.40 & 11.15 & 2.20 & 1.32 & 2.20 & 1.90 & 2.34 & 90.03 & 5.72 & 4.25 & NA & 23.69 \\
\hline
\end{tabular}


by secondary carbonate and opaline silica (fig. 5). The sandy slope-wash alluvium (unit 3 ) and the veins are unconformably overlain by two fine-grained depositional units consisting of slope wash and eolian sand and silt (units 1 and 2).

In the following discussions of the units, colors refer to the $<2$-mm particle-size fraction, unless otherwise stated. Soil textures refer to the $<2$-mm fraction in which secondary carbonate, opaline silica (where present), and organics have been removed.

\section{Unit 1}

Unit 1 is a pale brown (10YR 6/3), gravelly silty sand, with a soft consistence. It contains moderately sorted, subangular to subrounded sand, and less than 30 percent angular to subrounded pebble-cobble gravel. Unit 1 appears to be mostly eolian, based on the uniform sorting, particle size distribution, and lack of coarse gravel (table 3 ). Secondary carbonate forms thin coatings on the underside of pebbles. The basal contact is wavy. This unit is correlated, on the basis of its stratigraphic position and its physical and chemical properties, with similar deposits in the Yucca Mountain region which are dated or inferred to be latest Pleistocene to early Holocene (Taylor, 1986). Within unit 1, there are two discrete soil horizons.

The $A v$ horizon is a pale brown (10YR $6 / 3$, dry) to dark brown (10YR 4/3, moist), moderately sorted, silty sand (soil texture: sandy loam) that contains less than 10 percent pebble gravel. The consistence is soft. The basal horizon boundary is abrupt and smooth, and the $A v$ horizon thickness ranges from less than 5 to $10 \mathrm{~cm}$.

The $B t k$ horizon is a pale brown (10YR $6 / 3$, dry) to dark brown (10YR 4/3, moist), moderately sorted, silty sand (soil texture: loamy sand to sandy loam) that contains from 15 to 30 percent pebble-cobble gravel. Clasts within the gravel are angular to subrounded and are as large as $20 \mathrm{~cm}$ across. The Btk horizon is generally nonbedded but contains a few stone lines near its base (pl. 1E, E37S-E39S). The consistence is soft. The secondary carbonate forms thin coatings on the underside of pebbles (stage $I$ ). The basal horizon boundary is abrupt and wavy, and the $B t k$ horizon thickness ranges from 10 to $60 \mathrm{~cm}$.

\section{Unit 2}

Unit 2 is a light-yellowish-brown to yellowishbrown (10YR 5-6/4), compact, silty sand, and contains from 5 to 20 percent angular to subangular pebblecobble gravel. The sand is moderately sorted, and subangular to subrounded. Near the base of unit 2, indurated plates from unit 3 , which are cemented by secondary-carbonate and opaline silica, have been reworked into the fine-grained matrix. Unit 2 has been dated at $38 \pm 10 \mathrm{ka}$ (pl. 1E, 31S) and $55 \pm 20 \mathrm{ka} \mathrm{(pl.} \mathrm{1E,}$ 32S) (table 4) (Swadley and others, 1984; Rosholt and others, 1985). Unit 2 pinches out downslope (pl. 1F, E42S). Within unit 2 there are two discrete soil horizons.

Table 4. Uranium-trend and uranium-series ages for deposits exposed in trench 14

[Uranium-trend from Swadley and others (1984) and Rosholt and others (1985); and Uranium-series from Stuckless and others, 1991. Sample locations for YM-14 are shown on plate 1E (26S); and on plate 1D, TSV412 (B14S), HD-42 (D14S); and HD-1 (C18S); \pm , plus or minus; ND, no data; $>$, greater than; $+\infty$, plus infinity]

\begin{tabular}{|c|c|c|c|}
\hline $\begin{array}{l}\text { Sample } \\
\text { number }\end{array}$ & $\begin{array}{l}\text { Material } \\
\text { sampled }\end{array}$ & $\begin{array}{l}\text { U-trend } \\
\text { (103 } \\
\text { years) }\end{array}$ & $\begin{array}{l}\text { U-Series } \\
\text { (103 years) }\end{array}$ \\
\hline YM-14 B1-9 & Unit 2 & $38 \pm 10$ & ND \\
\hline YM-14 2-9 & Unit 2 & $55 \pm 20$ & ND \\
\hline YM-14 10-14 & Unit 3 & $270 \pm 90$ & ND \\
\hline YM-14 15-17 & Unit 3 & $420 \pm 50$ & ND \\
\hline YM-14 18-22 & Unit 3 & $488 \pm 90$ & ND \\
\hline TSV-412-1 & $\begin{array}{l}\text { Unit 3, dense } \\
\text { opaline string- } \\
\text { ers above main } \\
\text { fault zone }\end{array}$ & $\begin{array}{c}>350 \text { and } \\
>400\end{array}$ & ND \\
\hline TSV-412-3 & & $>550$ & ND \\
\hline TSV-412-7 & & $>440$ & ND \\
\hline HD 42-5 & Vein III center & ND & $228+11$ \\
\hline HD 42-5 & Vein III near wall & ND & $324(+\infty,-69)$ \\
\hline HD 1 & Unit 3-upper part & ND & $88+5$ \\
\hline
\end{tabular}

The $2 B t j$ horizon is a yellowish-brown (10YR 5-6/4, dry) to dark-yellowish-brown (10YR 3-4/4, moist), compact, moderately sorted, silty sand (soil texture: sandy loam) that contains from less than 5 to 10 percent pebble-cobble gravel. Clasts within the gravel are angular to subangular and are large as $15 \mathrm{~cm}$ across. The horizon has a well-developed soil prismatic structure. The basal horizon boundary is clear and wavy, and the $2 B t j$ horizon thickness ranges from 0 to $30 \mathrm{~cm}$. 
The $2 B+K$ horizon is light-yellowish-brown (10YR 6/3-4, dry) to pale brown (10YR 6/3, moist), and white (10YR 8/0, dry and moist), slightly compact and indurated, moderately sorted, sandy silt (soil texture: sandy loam) that contains from less than 5 to 20 percent pebble-cobble gravel. Clasts within the gravel are angular to subangular and are as large as $15 \mathrm{~cm}$ across. The horizon contains plates that are cemented by carbonate (stage IV) and opaline silica (stage 4) that have been moved up from or downslope from the $3 \mathrm{Kmql}$ horizon, which is immediately below $2 B+K$ horizon. The basal horizon boundary is abrupt and smooth, and the $2 B+K$ horizon thickness ranges from 0 to $15 \mathrm{~cm}$.

\section{Unit 3}

Unit 3 is a white to light gray (10YR 7-8/0-2), moderately well- to well-sorted sand to silty sand, pebble-cobble gravel, and contains rare boulders. The consistence is from soft to extremely hard where the unit is indurated by secondary carbonate and opaline silica. The sandy matrix is weakly to well cemented. Carbonate along fracture surfaces is common (pl. 1E, 27S, 31S; pl. 1F, 47S, 54S).

Unit 3 can be correlated on the basis of physical and chemical characteristics to a sand sheet unit, unit Q2s, described by Hoover and others (1981). Ash of the Bishop Tuff is present in several places at or near the base of unit Q2e, an eolian unit from which the sand sheets were derived. The presence of this ash places a constraint of $<730 \mathrm{ka}$ on the age of Q2s and unit 3.

Unit 3 yields progressively older ages of $88 \pm 5 \mathrm{ka}$ (D.R. Muhs, U.S. Geological Survey, written commun., 1989) (table 4), 270 $\pm 90,420 \pm 50$, and $480 \pm 90 \mathrm{ka}$ (Rosholt and others, 1985) (table 4) (pl. 1E, $26 S$ ). Because the oldest age approaches the maximum age for the U-trend method, the unit may be considerably older. The uppermost part of unit 3 (3Kmql) has a $\mathrm{U}$-series age of $88 \pm 5 \mathrm{ka}$, indicating a long and continuous period of horizon formation since deposition. Over time, continuous translocation of carbonate and its reprecipitation at depth tend to plug horizons, forcing them to grow upward; as a result, the progressively younger ages toward the surface of the maximally developed $K$ horizon of unit 3 indicate a long and continuous period of soil formation. An opaline silica band, which is in the maximally developed $K$ horizon above the main fault zone and which continues into the slope-wash alluvium (pl. 1D, B14S) is dated at $>350$, $>440,>400$, and $>550 \mathrm{ka}$ or is older than the sensitivity of the technique (table 4). Within unit 3 , there are five discrete soil horizons.
The $3 K m q 1$ horizon is white (10YR 8/0, dry; 10YR $8 / 2$, moist), well-sorted, silty sand (soil texture: loamy sand) that contains 20 percent pebblecobble gravel with clasts as large as to $20 \mathrm{~cm}$ across. The horizon is indurated and characterized by carbonate, and by opaline silica-cemented plates (stage 4). As much as 10 percent of this horizon is composed of discrete opaline silica stringers that form sandwich-like zones within the platy carbonate. Discrete plates vary in length from 5 to $40 \mathrm{~cm}$ and in width from 3 to $10 \mathrm{~cm}$. This horizon is continuous, but obviously fractured, over the main fault zone (pl. 2, B11-15N) and the bedrock on the upthrown side of the fault (pl. 1D, B1113S). In places, $3 \mathrm{Kmql}$ merges with the vein filling (pl. 1B, C13N). The horizon contains lenses that consist of as much as 80 percent white (10YR 8/0, dry; 10/3, moist) ooidic carbonate (p1. 1C, top of A4S). The basal horizon boundary is abrupt and wavy, and $3 K m q 1$ horizon thickness ranges from 0 to $50 \mathrm{~cm}$.

The $3 K m q 2$ horizon is white (10YR $8 / 2$, dry) to very pale brown (10YR $8 / 3$, moist), sand to silty sand. The $3 K m q 2$ horizon is very similar to $3 K m q 1$. The discrete plates in this horizon are considerably smaller than in $3 \mathrm{KmqI}$ and vary in length from 5 to $10 \mathrm{~cm}$ and in width from 3 to $5 \mathrm{~cm}$. This horizon thins and the plates decrease in size, downslope away from the main fault. Downslope, the horizon also contains a greater percentage of infiltrated fine-grained sediments (pl. 1F, F45S) until, in some places, the carbonate plates float in a matrix of the fine-grained sediment (pl. 1E, E27S). There is evidence of animal burrowing, but the displacement of the plates by the infiltrated finegrained sediments seems to be due primarily to soil creep. The basal horizon boundary is abrupt and wavy, and the $3 \mathrm{Kmq} 2$ horizon thickness is from 0 to $50 \mathrm{~cm}$.

The $3 K q$ horizon is white ( $10 \mathrm{YR} 8 / 0$, dry; 10YR $8 / 2$, moist), moderately well-sorted, silty sand (soil texture: sandy loam) that contains from 5 to 40 percent pebble gravel with clasts as large as $4.5 \mathrm{~cm}$ across. This horizon is indurated by secondary carbonate (stage III) and contains thin stringers of opaline silica (stage 3 and 4 in places). In places, as much as 50 percent of the horizon is ooidic carbonate. The horizon contains filled animal burrows (pl. 1E, E31S-E32S). The basal horizon boundary is abrupt and smooth, and the $3 \mathrm{Kq}$ horizon thickness ranges from 0 to $50 \mathrm{~cm}$. 
The $3 B k q l$ horizon is white (10YR $8 / 2$, dry) to brown (10YR 5/3, moist), nonbedded and poorly sorted, silty sand (soil texture: loamy sand) that contains from 15 to 20 percent subangular to subrounded pebble-cobble gravel. The consistence is soft except for stringers of carbonate-cemented gravel. Within the horizon, stringers consist of dense continuous carbonate (stage III). Between stringers, carbonate forms continuous coats on the underside of gravel clasts with some matrix bridging (stage II). Lenses within the stringers are entirely ooidic carbonate. Opaline silica stringers $<4 \mathrm{~mm}$ thick are present, but rare, within the carbonate stringers. Carbonate stringers within the horizon are more massive and dip more steeply in the slope-wash alluvium that is adjacent to the main fault zone than they do downslope. The carbonate stringers are almost parallel to the bedrock adjacent to the main fault zone. Abundance and prominence of carbonate stringers and coarser gravel distinguish this horizon from the horizon below ( $3 B k q 2)$. A filled animal burrow is evident (pl. 1E, F31S). The basal horizon boundary is abrupt and wavy, and the $3 B k q I$ horizon thickness ranges from 50 to $175 \mathrm{~cm}$.

The $3 B k q 2$ horizon is white to light gray (10YR 7-8/2, dry) to brown (10YR 5/3, moist), sand to silty sand (soil texture: loamy sand to sandy loam) that contains from 10 to 15 percent angular to subrounded pebbles and cobbles as large as $16 \mathrm{~cm}$ across. The consistence is soft. The horizon is less consolidated than horizon $3 B \mathrm{kql}$ and increases in thickness away from the main fault as carbonate stringers in above horizon decrease. Contains lenses that are entirely ooidic carbonate. The basal horizon boundary is not exposed, and the $3 B k q 2$ horizon thickness that is exposed ranges from 0 to $60 \mathrm{~cm}$.

\section{Colluvium}

Immediately adjacent to the bedrock and stratigraphically below unit 3 , two wedges of colluvium [two on the north wall (pl. 1B) and one on the south wall (pl. 1D)] can be distinguished from the slope-wash alluvium. The colluvium is white to light gray (10YR $7-8 / 0-2)$, soft to hard where cemented by carbonate and opaline silica, poorly sorted, and poorly bedded sand to silty sand pebble-cobble gravel. The gravel content grades from about 50 to 80 percent as depth increase. The gravel is coarser in the colluvium than in the slopewash alluvium. The sandy matrix is weakly to wellcemented. The fabric, defined by crude bedding and subparallel stringers and laminae of carbonate and opaline silica, dips $15^{\circ} \mathrm{W}$ in the upper part of the unit and $30^{\circ} \mathrm{W}$ in the basal part.

\section{Origin of Secondary Calcium Carbonate and Opaline Silica}

The abundance of secondary carbonate and opaline silica in the slope-wash alluvium and veins has drawn the attention of many people who have seen the exposures in trench 14. Concern arose as to whether these materials were deposited from infiltrating meteoric water or from upwelling ground water or perched water. Translocation of carbonate and opaline silica by infiltrating meteoric water result from pedogenic processes that are described more fully below. Criteria for distinguishing pedogenic and non-pedogenic carbonate and opaline silica are summarized in table 5 and discussed in this section.

Laminated carbonate and opaline silica deposits are common in sediments of Quaternary age throughout the arid and semiarid parts of the southwestern United States. The processes that form these deposits also form carbonate- and opaline silica-enriched soil horizons. Carbonate is leached from the surface and upper horizons of soils by downward-percolating meteoric water and subsequently precipitates in lower soil horizons at a depth controlled by soil moisture and texture (McFadden and Tinsley, 1985). Over thousands of years, calcium carbonate-rich horizons form from the continual translocation of $\mathrm{Ca}^{++}$and the subsequent precipitation of carbonate. Soils in these sediments have variations in the concentration and morphology of these secondary constituents because of the combined effects of (1) the age of the soil; (2) the concentration and seasonal distribution of $\mathrm{Ca}^{++}$and readily soluble silica in precipitation; (3) the initial carbonate and silica content of a deposit; and (4) the rate of influx of calcium- and silica-bearing eolian dust.

At Yucca Mountain, the soil parent material is chiefly silicic volcanic rock, containing little or no carbonate and only small concentrations of calcium. In this area, the calcium accumulated in soils is derived primarily from the influx of eolian dust (Gile and others, 1966, 1981; Bachman and Machette, 1977). Calcium is dissolved from the dust at and near the surface by percolating meteoric water. A small contribution to the carbonate may be derived from in-situ leaching of calcium from the parent material. Carbon dioxide is contributed by, or equilibrated with, $\mathrm{CO}_{2}$ that is derived from the atmosphere through root respiration. The calcium and $\mathrm{CO}_{2}$ are subsequently combined and precipitated as secondary carbonate at depth. 
Table 5. General criteria for distinguishing nonpedogenic from pedogenic calcium carbonate and opaline silica

$\left[\%\right.$, percent; $>$, greater than; $<$, less than; $\ll<$, much less than; $1^{\circ}$, primarily $]$

Factor
1. Geomorphology, spatial
arrangements.
2. Location of the initial
$\mathrm{CaCO}_{3}$ and opaline $\mathrm{SiO}_{2}$
deposition in a gravelly
deposit. ${ }^{3,4}$
3. $\mathrm{Physical}^{\text {characteristics of }}$
maximally developed
$\mathrm{CaCO}_{3}$.
4. $\mathrm{Change}^{\text {in concentration of }}$
$\mathrm{CaCO}_{3}$ and opaline SiO
with depth.
1,2,4

5. General distinguishing petrographic and mineralogic characteristics.

6. Ca:Mg ratio of clay minerals. $^{2}$

7. $\mathrm{CaCO}_{3}$ crystallinity and percent.

8. Opaline $\mathrm{SiO}_{2} \%$ and crystallinity. ${ }^{8,11}$

9. $\delta^{13} \mathrm{C}$ vs $\delta^{18} \mathrm{O}$ in $\mathrm{CaCO}_{3}{ }^{12}$; $\delta^{13} \mathrm{C}$ is vegetation dependent and $\delta^{18} \mathrm{O}$ is dependent on mineralization temperature of $\mathrm{CaCO}_{3}$ and fluid source.

10. $\delta \mathrm{D}$ vs $\delta^{18} \mathrm{O}$ in $\mathrm{CaCO}_{3}{ }^{12,14,15}$

\section{Nonpodogenic}

Isolated points at or near springs, down-slope of fractures or faults in bedrock or surficial deposits. ${ }^{1}$

Random orientation, gravel remains in contact (clast supported); bedding features may be preserved.

Discrete stratiform; mounded, or draped strata; commonly displaying vegetative molds and vugs. ${ }^{1}$

No systematic change, uniform deposition.

High temp-no ooids; 7 $1^{\circ}$ opal-C. ${ }^{8}$ Low temp-few ooids; ${ }^{7} 1^{\circ}$ opal-A. ${ }^{8}$ Both are poorly stratified ${ }^{7}$ and have common sulfide, sulfate, and manganese minerals. ${ }^{7}$

No systematic depletion of $\mathrm{Mg}^{++}$over time when compared to $\mathrm{CaCO}_{3}$ precipitation.

Coarse sparry calcite crystals, microsparite, and sparite; crystals $>99.5 \%$ pure. $^{1}$

Silcrete, $>85 \% \mathrm{SiO}_{2}$, amorphous $\mathrm{SiO}_{2}$ to coarsely crystalline quartz.

Expected range within concentrations reported for spring deposited $\mathrm{CaCO}_{3}$.

Shift in $\delta^{18} O$ concentrations away from the concentrations for meteoric water.

\section{Pedogenic}

Follow topography and geomorphic surfaces, laterally persistent. $^{2}$

Deposition on the underside of clasts; gravel does not remain in clast contact (matrix supported); bedding features lost or poorly preserved in advanced stages.

Continuous laminar layers underlain by bedrock or a plugged horizon. 2,3

Decreases with depth below a near-surface maximum.

Ooids common; ${ }^{7}$ usually opal-CT; ${ }^{8}$ well stratified; 7 common smectitic and illitic clay minerals. ${ }^{9}$

Progressive depletion of $\mathrm{Mg}^{++}$ in comparison to the accumulation of secondary $\mathrm{CaCO}_{3}$; formation of $\mathrm{Mg}$-rich clays.

Microcrystalline (micrite), crystallitic b-fabric; ${ }^{10}$ commonly clay, $\mathrm{MgCO}_{3}$, and opaline $\mathrm{SiO}_{2}$ present; $<99.5 \%$ pure. $^{11}$

Duripan, $\ll 85 \%$ amorphous opaline $\mathrm{SiO}_{2}$.

Expected range within concentrations reported for pedogenic $\mathrm{CaCO}_{3}$. ${ }^{13}$

No shift in $\delta^{18} \mathrm{O}$ concentrations away from the concentrations for meteoric water.

\section{Observed In trench 14}

Laterally persistent in

slope-wash alluvium.

Initial deposition on the underside of gravel, matrix supported; bedding features lost or poorly preserved.

Continuous laminar layers that have formed plates. ${ }^{5}$

Decreases with depth below a near-surface maximum. ${ }^{6}$

Ooids common; primarily opal-CT; well stratified; common smectitic and illitic clay minerals. $^{\text {? }}$

Formation of $\mathrm{Mg}$-rich clays including sepiolite and palygorskite.

Microcrystalline, crystallitic b-fabric with clay and opaline $\mathrm{SiO}_{2} ;>70 \%$ pure.

Duripan, $<85 \%$ amorphous opaline $\mathrm{SiO}_{2}{ }^{7}$

Range within concentrations reported for pedogenic $\mathrm{CaCO}_{3}{ }^{12,13}$

Concentrations are equal to those of meteoric water. ${ }^{12}$ 
Table 5. General criteria for distinguishing nonpedogenic from pedogenic calcium carbonate and opaline silica --Continued

\begin{tabular}{|c|c|c|c|}
\hline Factor & Nonpedogenic & Pedogenic & Observed In trench 14 \\
\hline $\begin{array}{l}\text { 11. } \mathrm{Pb}\left({ }^{204} \mathrm{~Pb},{ }^{206} \mathrm{~Pb},{ }^{208} \mathrm{~Pb}\right) \\
\text { isotopes; }{ }^{16} \text { reflects the } \\
\text { isotopic composition of } \\
\text { the rocks with which the } \\
\text { water that precipitated the } \\
\mathrm{CaCO}_{3} \text { was in contact. }\end{array}$ & $\begin{array}{l}\text { Dominated by isotopic concen- } \\
\text { trations different from that of } \\
\text { the soil parent material or, in } \\
\text { the veins, the adjacent } \\
\text { bedrock. }\end{array}$ & $\begin{array}{l}\text { Dominated by isotopic concen- } \\
\text { trations of the soil parent } \\
\text { material, or the veins, the } \\
\text { adjacent bedrock. }\end{array}$ & $\begin{array}{l}\mathrm{Pb} \text { isotopic composition very } \\
\text { similar to bedrock from which } \\
\text { the slope-wash alluvium is } \\
\text { derived and through which the } \\
\text { veins penetrate. } 16\end{array}$ \\
\hline $\begin{array}{l}\text { 12. Sr isotopes; }{ }^{17} \text { geochemical } \\
\text { analog to } \mathrm{Ca}^{++} \text {; indicates } \\
\text { the isotopic composition } \\
\text { of the rocks with which } \\
\text { the water that precipitated } \\
\text { the } \mathrm{CaCO}_{3} \text { was in contact. }\end{array}$ & $\begin{array}{l}\text { Expected }{ }^{87} \mathrm{Sr} /{ }^{86} \mathrm{Sr} \text { concentra- } \\
\text { tions within the range of inde- } \\
\text { pendently obtained samples } \\
\text { from ground water, spring } \\
\text { water, spring deposits, lime- } \\
\text { stone or volcanic tuffs, or } \\
\text { both. }\end{array}$ & $\begin{array}{l}\text { Expected }{ }^{87} \mathrm{Sr} /{ }^{86} \mathrm{Sr} \text { concentra- } \\
\text { tions within the range of inde- } \\
\text { pendently obtained samples } \\
\text { from soils developed on stable } \\
\text { alluvial surfaces or from } \\
\text { eolian samples. }\end{array}$ & $\begin{array}{l}{ }^{87} \mathrm{Sr} /{ }^{86} \mathrm{Sr} \text { concentrations in the } \\
\text { slope-wash alluvium and } \\
\text { veins are similar to indepen- } \\
\text { dently obtained soil and } \\
\text { eolian samples. }{ }^{17}\end{array}$ \\
\hline $\begin{array}{l}\text { 13. U-series }\left({ }^{238} \mathrm{U},{ }^{234} \mathrm{U} \text {, and }\right. \\
{ }^{230} \mathrm{Th} \text { ) isotopes }{ }^{19} \text { indi- } \\
\text { cates the isotopic compo- } \\
\text { sition of the rocks with } \\
\text { which the water that } \\
\text { precipitated the } \mathrm{CaCO}_{3} \\
\text { was in contact. }\end{array}$ & $\begin{array}{l}\text { Dominated by isotopic concen- } \\
\text { trations similar to samples } \\
\text { independently obtained from } \\
\text { ground water and spring } \\
\text { water. }^{18}\end{array}$ & $\begin{array}{l}\text { Dominated by isotopic concen- } \\
\text { trations from samples inde- } \\
\text { pendently obtained from soil } \\
\text { and eolian samples. }{ }^{19}\end{array}$ & $\begin{array}{l}\text { U-series concentrations in the } \\
\text { slope-wash alluvium and } \\
\text { veins are similar to indepen- } \\
\text { dently collected soil and } \\
\text { eolian samples. }{ }^{18}\end{array}$ \\
\hline $\begin{array}{l}\text { 14. Ostracodes-a calcareous } \\
\text { microfossil that requires a } \\
\text { saturated and oxygenated } \\
\text { environment. Species are } \\
\text { dependent on water tem- } \\
\text { perature and chemistry. }\end{array}$ & $\begin{array}{l}\text { Almost always in spring } \\
\text { deposits. }\end{array}$ & $\begin{array}{l}\text { Not present, or if present in a } \\
\text { soil environment, are part of } \\
\text { the eolian component, and } \\
\text { external surfaces must have } \\
\text { evidence of wind abrasion. }\end{array}$ & No ostracodes were present. ${ }^{20}$ \\
\hline 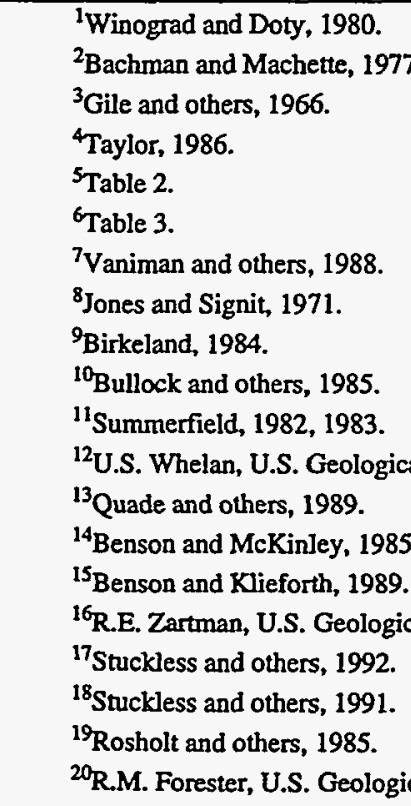 & I Survey, written commun., 1989. & & \\
\hline
\end{tabular}


Secondary carbonate is concentrated at the bedrock-alluvium contact in trench 14 by increased runoff from the less-permeable bedrock that is upslope (figs. 6 and 7, pl. 1B and 1D). The concentration of secondary carbonate decreases with distance from the bedrockalluvium contact. Most of the runoff percolates into the near-vertical fractures (forming veins) in the Bow Ridge Fault zone bedrock, and into the slope-wash alluvium at the bedrock contact. The available moisture decreases downslope away from the bedrockalluvium contact.

Pedogenic silica cementation is common in the soils in the Yucca Mountain region (Taylor, 1986). The morphology of opaline silica varies with age. Stages of development are listed in table 1. Opaline silica is common in soils that are developed in parent material containing readily soluble silica-rich glass, as is characteristic of pyroclastic rocks in the Yucca Mountain region. Eolian influx of readily soluble silica-rich dust also is a source of silica.

In general, two terms are used for soil layers cemented with opaline silica: (1) Duripan-specifically applied to pedogenic accumulations (Soil Survey Staff, 1975) and (2) silcrete-for more generic geologic accumulations (Summerfield, 1982, 1983;

Nettleton and Peterson, 1983). Both terms are applied to an indurated product of surficial and near-surface silicification, formed by the cementation or replacement of bedrock, unconsolidated sediments, or soil. Duripans and silcretes are produced by low-temperature physiochemical processes and are not produced by metamorphic, volcanic, or plutonic processes associated with deep burial or by diagenetic processes associated with more moderate burial. Silcretes are almost exclusively present in saturated ground-water environments. No minimum silica content is defined for a duripan, whereas a silcrete has an arbitrary lower limit of 85 percent silica by weight (Summerfield, 1982, 1983).

No silcretes are present in the Yucca Mountain region (Taylor, 1986), but duripans are common. They vary in cementation by secondary opaline silica and commonly contain accessory cements, mainly carbonate.

Conspicuously well-laminated carbonate and opaline silica have been deposited along several fault planes within the Bow Ridge Fault zone at trench 14. Because the unconsolidated sandy slope-wash alluvium could not support open fractures very long, the laminae probably record episodes of opening and incremental filling of fractures developed along the fault. Similarly, the ash-filled fractures indicate that open fractures were formed and then subsequently filled through the action of surficial processes.
Finally, the modern water table ranges from 300 to $670 \mathrm{~m}$ below the surface in the Yucca Mountain region. There is no evidence from the area immediately adjacent to Yucca Mountain to indicate that rises in the water table have occurred during the last $500 \mathrm{ka}$ (Winograd and Doty, 1980). Spring deposits do exist, however, west of Yucca Mountain at the south end of Crater Flat (fig. 1), and in the Amargosa area.

The following physical, chemical, biological, petrographic, isotopic, and mineralogical properties indicate that the secondary carbonate and opaline silica exposed in trench 14 were deposited from infiltrating meteoric water (table 5):

1. The spatial arrangements of spring and pedogenic deposits are different. Spring deposits tend to be isolated points at or near springs or paleosprings in bedrock or surficial deposits (Winograd and Doty, 1980). Pedogenic deposits follow the topography or geomorphic surface and are laterally persistent (Bachman and Machette, 1977). The carbonate- and opalinesilica-enriched zones exposed in the slopewash alluvium in trench 14 are laterally persistent and are characteristic of a mapped unit in the Yucca Mountain region (Swadley and others, 1984).

2. The location of the initial precipitation of soluble salts, including carbonate, in a spring deposit is different from that of pedogenic deposits in a gravelly soil. Clasts tend to remain in contact and bedding features are preserved in a spring deposit as carbonate randomly fills voids. In contrast, pedogenic carbonate is initially precipitated on the underside of clasts within a gravelly soil. Over time, these gravel coatings tend to merge and eventually plug entire horizons (Gile and others, 1966). In advanced stages of soil carbonate accumulation, clasts are no longer in contact and the bedding features are lost as carbonate precipitates and mechanically separates the gravel. In the slope-wash alluvium exposed in trench 14 , carbonate has precipitated on the underside of gravel. Bedding features are not preserved in the zones of maximum carbonate accumulation. Soils in the Yucca Mountain region develop a silica morphology very similar to carbonate morphology (table 1). 
3. In physical characteristics, spring deposits are typically stratiform, have a mound or draped form, and commonly display vegetative molds and vugs (Winograd and Doty, 1980). Pedogenesis produces continuous layers or horizons of accumulated carbonate underlain by bedrock or a plugged carbonate horizon (Gile and others, 1966; Bachman and Machette, 1977). In trench 14, the continuous layers, which in places have weathered to plates, are typical of pedogenic accumulations that are present seen elsewhere in the Yucca Mountain region (Taylor, 1986). These laminar horizons are continuous over the veins (figs. 6 and 7, pl. 1B and 1D).

4. In a soil, the concentration of secondary carbonate decreases with depth below the zone of maximum carbonate accumulation present (Taylor, 1986). The maximum accumulation is frequently described as the carbonate bulge. A spring deposit also may have a systematic decrease in the abundance of carbonate with depth; however, the morphology and obvious horizontal zonation that is typical of pedogenic deposits are lacking. The accumulations of secondary carbonate exposed in trench 14 have the characteristic pedogenic decrease with depth below a maximum accumulation (table 3).

5. General petrographic and mineralogic characteristics can be used to distinguish spring and pedogenically precipitated carbonate and opaline silica. Ooids are uncommon or absent in spring deposits but are common in pedogenic deposits (Vaniman and others, 1988). Springdeposited carbonate tends to be poorly stratified, whereas soil carbonate tends to be wellstratified (as observed in thin section) (Vaniman and others, 1988). In trench 14, carbonate in the veins and slope-wash alluvium commonly has an ooidic structure and is well stratified (fig. 10).

Three types of opal structures are commonly identified, using criteria developed by Jones and Signit (1971). The three types are: (1) amorphous (opal-A), (2) opal that has shortrange tridymite and cristobalite-type stacking (opal-CT), and (3) opal that has more extensive

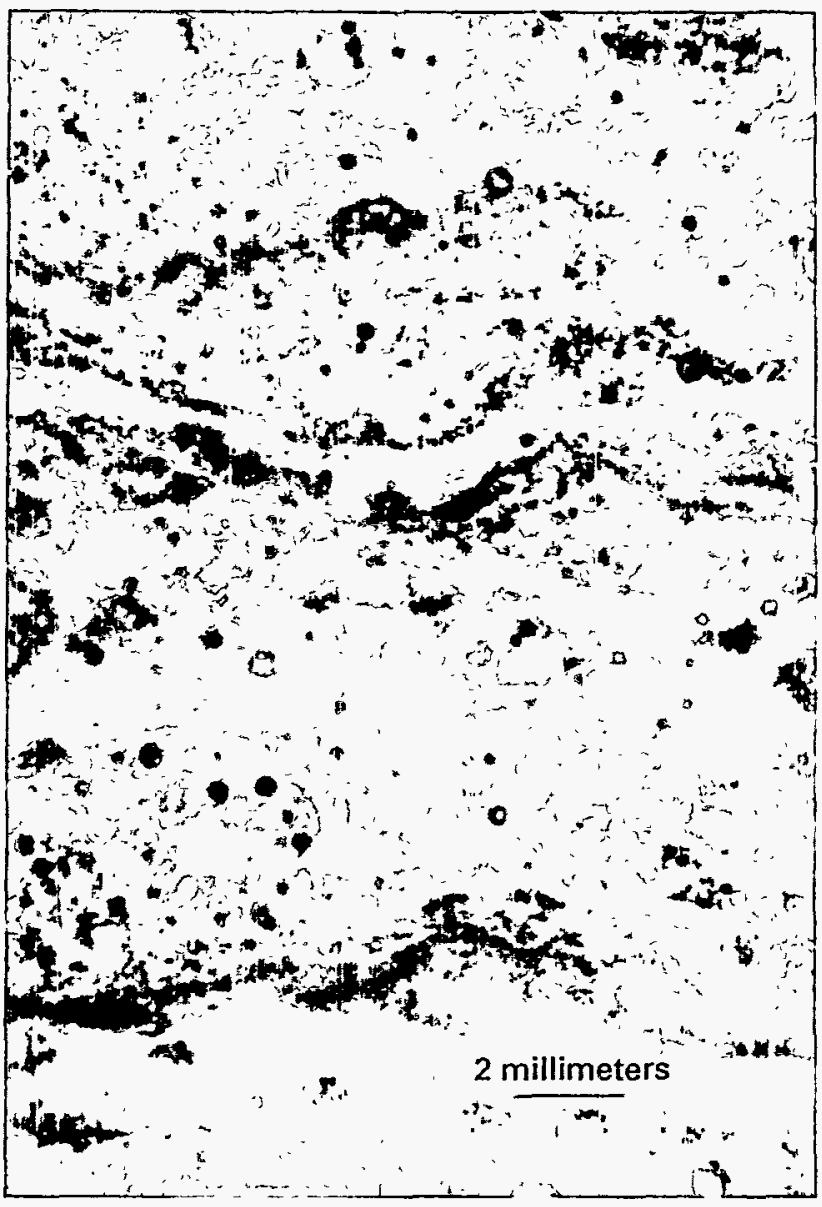

Figure 10. Photomicrograph of microcrystalline-banded carbonate with a crystallitic b-fabric. Material consists of fine particles of calcite mixed with clay particles.

domains of cristobalite-type stacking (opal-C). Opal-C is typically present in hightemperature spring deposits and veins, opal-A in low-temperature spring deposits, and opal-A and opal-CT in pedogenic deposits. Where opal-A is present in soils in the Yucca Mountain region, it commonly forms as fossilization of plant roots (D.T. Vaniman, Los Alamos National Laboratory, oral commun., 1990). Opal in pedogenic deposits in the Yucca Mountain region is chiefly opal-CT (Taylor, 1986). The dense opaline silica stringers in the veins and silica cement in the slope-wash alluvium in trench 14 have a botryoidal structure and are chiefly opal-CT (figs. 11 and 12). The presence of opal-CT indicates precipitation at ambient air temperature (Jones and Signet, 1971).

Sulfide, sulfate, and manganese minerals are 
common in high-temperature spring deposits and veins (Vaniman and others, 1988). Clays present in desert soils are chiefly smectite, illite, and mixed-layer smectite-illite (Birkeland, 1984). Smectitic and illitic clay minerals are present in the veins and in the slope-wash alluvium exposed in trench 14.

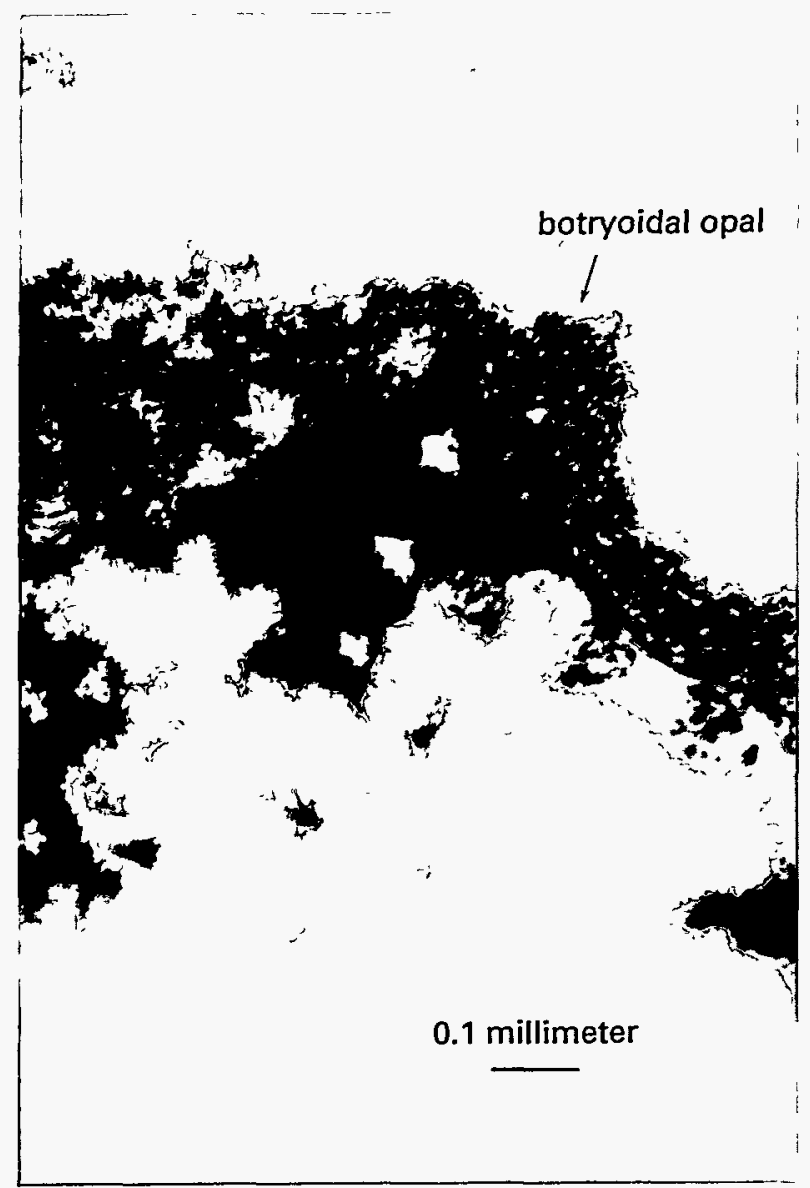

Figure 11. Photomicrograph of botryoidal opal filling a void. Botryoidal opal was identified in the veins and adjacent slope-wash alluvium.

6. Soil $\mathrm{Ca}: \mathrm{Mg}$ ratios indicate a progressive increase in the ratio over time in the clay minerals in the carbonate-enriched horizons of a calcic soil (Bachman and Machette, 1977)—-the older the soil, the higher the Ca:Mg ratio. This systematic trend is not characteristic of the clay mineralogy of spring deposits (Vaniman and others, 1988). Sepiolite and palygorskite, which are Mg-rich clay minerals, are present in the carbonate-enriched vein fillings and $K$ horizons in the slope-wash alluvium exposed in trench 14. These minerals are not unique to soils (Vaniman and others, 1988), but they are typical of pedogenic deposits in the southern Nevada region (Jones, 1983).

7. The crystallinity and purity of carbonate also can be used to distinguish between nonpedogenic and pedogenic sources of carbonate and opaline silica. Spring-deposited carbonate tends to have coarse sparry calcite crystals, microsparite, and sparite, or some combination of these; it is greater than 99.5 percent pure calcium carbonate (Winograd and Doty, 1980).

Pedogenically precipitated carbonate is micrite that has a crystallitic b-fabric (Bullock and others, 1985). It commonly contains clay, $\mathrm{MgCO}_{3}$, and opaline silica and has considerably less than 99.5 percent calcium carbonate. Thin-section studies of the veins and slopewash alluvium in trench 14 indicate that the carbonate is micrite that has a crystallitic b-fabric (fig. 10). The carbonate includes impurities of clay and opaline silica and contains less than 70 percent calcium carbonate (table 3).

8. As with carbonate, the purity and crystallinity of opaline silica can be used to distinguish between nonpedogenic and pedogenic sources. Deposits in saturated ground-water environments that have accumulated secondary opaline silica are typically silcretes and thus contain greater than 85 percent opaline silica. This opaline silica grades from amorphous to crystalline (Summerfield, 1982; 1983). Duripans form through a pedogenic process (Soil Survey Staff, 1975), and have a concentration of secondary opaline silica that is usually considerably less than 85 percent. The silica is amorphous. In the Yucca Mountain region, opaline silica-rich layers in the maximally developed $K m q$ or $K q m$ horizons contain 20 to 45 percent opaline silica (Taylor, 1986). In trench 14 , the dense opaline silica-rich layers in the veins and in the slope-wash alluvium contains from about 15 to 50 percent opaline silica (D.T. Vaniman, oral commun., 1990). Almost pure opaline silica is concentrated in bands less than $1 \mathrm{~mm}$ thick; however, these accumulations are opal-A and often contain 

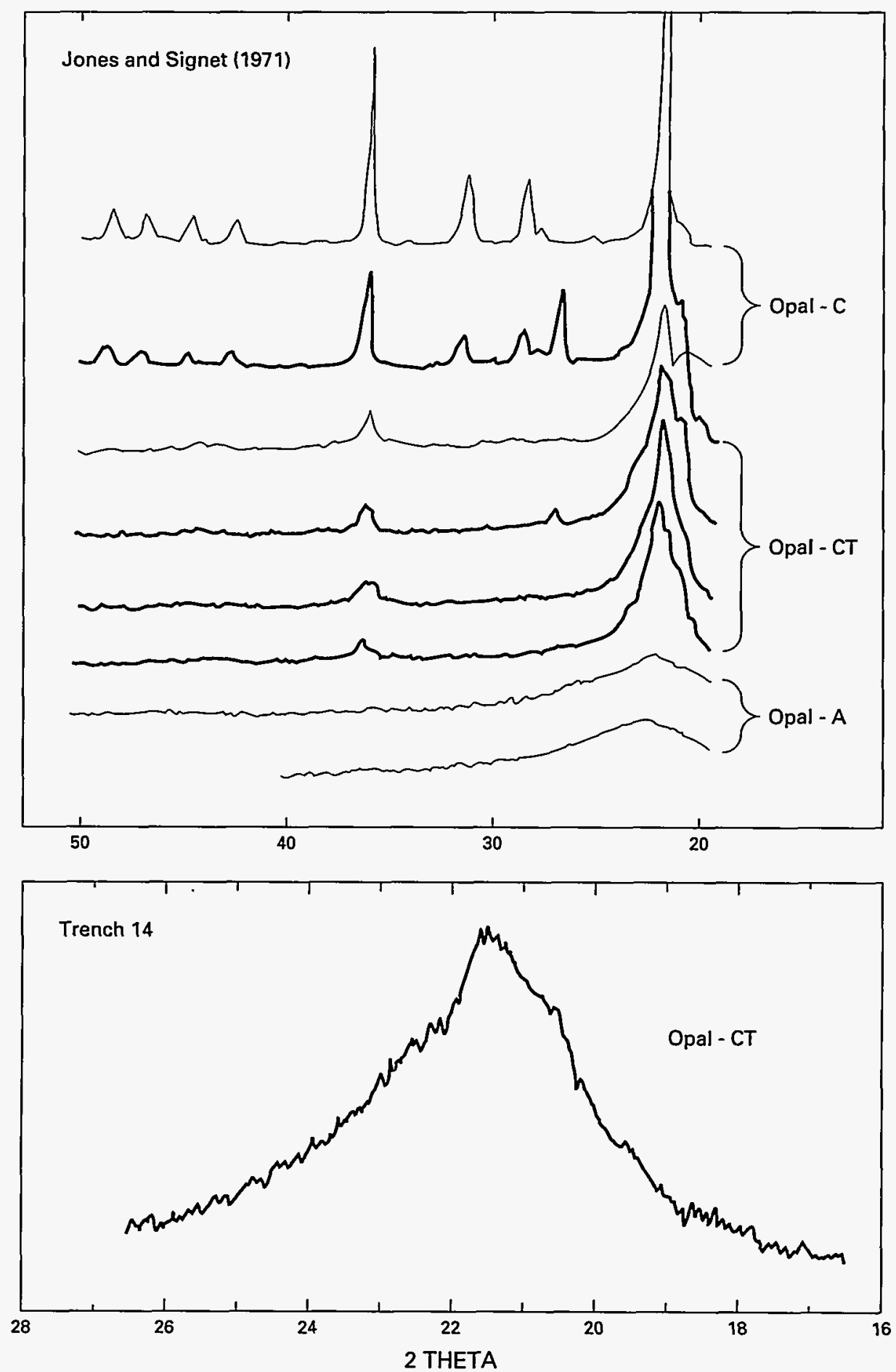

Figure 12. Representative $X$-ray diffraction trace showing opal-CT from an opaline silica stringer in trench 14. Note how condensed the Jones and Signet (1971) X-ray diffraction traces are in comparison to the trace from trench 14. 
remnants of root fossils (D.T. Vaniman, oral commun., 1990).

9. The concentration of $\delta^{13} \mathrm{C}$ in pedogenic calcrete deposits is a function of the dominant vegetation present when the secondary carbonate was precipitated. The concentration of $\delta^{18} \mathrm{O}$ is dependent on the mineralization temperature of the carbonate and on the source of the water from which the carbonate precipitated. Concentrations of $\delta^{13} \mathrm{C}$ and $\delta^{18} \mathrm{O}$ were measured in carbonate collected from the veins and slopewash alluvium exposed in trench 14 to distinguish nonpedogenic and pedogenic sources of the secondary carbonate (J.F. Whelan, U.S. Geological Survey, written commun., 1989; Quade and Cerling, 1990). The $\delta^{13} \mathrm{C}$ and $\delta^{18} \mathrm{O}$ concentrations were compared to concentrations reported for spring deposits and for samples collected from soils that developed on stable alluvial surfaces (Quade and others, 1989). The range of concentrations from trench 14 were similar to those reported for carbonate samples obtained from the soils (J.F. Whelan, U.S. Geological Survey, written commun, 1989; Quade and Cerling, 1990).

10. Concentrations of $\delta \mathrm{D}$ and $\delta^{18} \mathrm{O}$ were measured in carbonate collected from the vein fillings and slope-wash alluvium exposed in trench 14 to distinguish a nonpedogenic or pedogenic source (J.F. Whelan, U.S. Geological Survey, written commun., 1989). These values were compared to published values for meteoric water in the Yucca Mountain region (Benson and McKinley, 1985; Benson and Klieforth, 1989). The $\delta^{18} \mathrm{O}$ concentration of springdeposited carbonate shift away from the meteoric water line, while $\delta^{18} \mathrm{O}$ values from pedogenically precipitated carbonate plot on the water line. Samples collected from trench 14 have $\delta \mathrm{D}$ values consistent with values for meteoric water (J.F. Whelan, U.S. Geological Survey, written commun., 1989).

11. The concentration of $\mathrm{Pb}$ isotopes reflect the isotopic composition of the rocks in contact with the water that precipitated the carbonate. Isotopes ${ }^{204} \mathrm{~Pb}$, ${ }^{200} \mathrm{~Pb}$, and ${ }^{208} \mathrm{~Pb}$ were measured in carbonate collected from the vein fillings and slopewash alluvium (R.E. Zartman, U.S. Geological
Survey, written commun., 1989). If the carbonate was precipitated from ground water that had been in contact with bedrock that was different from the bedrock exposed in trench 14 and if that bedrock had a different isotopic signature, the isotopic signature of the veins would be different from the bedrock exposed in trench 14. However, if the carbonate was precipitated pedogenically, the isotopic signature would be dominated by that of the soil parent material, or, as in the veins, by the adjacent bedrock. All samples collected from trench 14 had a $\mathrm{Pb}$ isotopic signature very similar to that of the volcanic bedrock from which the slopewash alluvium is derived and which the veins penetrate (R.E. Zartman, U.S. Geological Survey, written commun., 1989).

12. Like $\mathrm{Pb}, \mathrm{Sr}$ values are inherited from the rock types in longest contact with the precipitating water. The concentration of ${ }^{87} \mathrm{Sr}$ and ${ }^{86} \mathrm{Sr}$ were measured in carbonate collected from the veins and slope-wash alluvium in trench 14 (Stuckless and others, 1991). The Sr values were measured for samples collected from ground water, spring water, spring deposits, local limestone, local volcanic rocks, soils, and eolian material. The ${ }^{87} \mathrm{Sr}$ and ${ }^{86} \mathrm{Sr}$ values in the veins and slope-wash alluvium from trench 14 are similar to those from soil and eolian samples collected in the vicinity of Yucca Mountain (Stuckless and others, 1991).

13. Like $\mathrm{Pb}$ and $\mathrm{Sr}$, Uranium-series values are records of the flow path of the precipitating water. $\mathrm{U}$-series $\left({ }^{238} \mathrm{U},{ }^{234} \mathrm{U}\right.$, and $\left.{ }^{230} \mathrm{U}\right)$ values were measured in carbonate collected from the veins and slope-wash alluvium in trench 14 (Stuckless and others, 1991). Samples were also collected from ground water and spring water and compared to reported values from soil in the Yucca Mountain region (Rosholt and others, 1985). The veins and slope-wash alluvium have U-series signatures similar to the regional soils and indicate precipitation of secondary carbonate from meteoric water rather than precipitation from ground or spring water.

14. Ostracodes are calcareous microfossils that require saturated conditions for a minimum of 3 months during a year. The environment must 
always be oxygenated. For these reasons, ostracodes are almost always present in spring environments (R.M. Forester, U.S. Geological Survey, oral commun., 1990). Species are dependent on the temperature and the chemistry of the water. If present in a soil, they are part of the eolian component, and the external surfaces of the ostracodes have evidence of wind abrasion. No ostracodes were present in the veins or slope-wash alluvium exposed in trench 14.

Trench 14 exposes at least three distinct silica deposits, in addition to the veins, in these non-vein silica deposits calcite is locally absent or a minor constituent. These silica deposits include (1) drusy quartz and chalcedony that line fractures and lithophysal cavities in the Tiva Canyon Member, (2) silica cement in fault breccia, and (3) chalcedony or opaline silica in the nonwelded tuff, or both. Preliminary ${ }^{18} 0 /{ }^{16} 0$ data indicate that the drusy quartz probably formed at somewhat higher temperatures than the opaline silica (S.S. Levy, LANL, written commun., 1989). The breccia cement is predominantly silica and other secondary minerals, such as calcite and sepiolite, are locally present.

The relation of the breccia cements to the opaline silica in the veins and soils is unclear. It has been proposed that the calcite and opaline silica cement in the silica-cemented fault breccia (SFB) and the cemented cataclastic fault breccia (CB) are probably much older and related to the cooling and Miocene faulting of the volcanic tuff, however, near-surface processes have affected the breccia cements (S.S. Levy, LANL, written commun., 1989). In the field, the cementing matrix in silica-cemented fault breccia is indistinguishable from and, in one place apparently continuous with, opaline silica stringers in the vein fillings (pl. 1D, bottom left of C13S, fig. 9). The tendency of the silica-cemented fault breccia to grade downward to the uncemented fault breccia (UFB) also indicates the effect of nearsurface processes or the later addition of the secondary cement from above. Levy has observed and described root casts in the cement (S.S. Levy, LANL, written commun., 1989), which also indicates the effect of surficial pedogenic processes. As mentioned in the unit descriptions, silicification in the cemented cataclastic fault breccia commonly decreases inward from a maximum at the edges where the unit is in contact with the veins. This decrease indicates that calcification and silicification of these fault breccias is related in some way to the deposition of the veins. Clasts of silicacemented fault breccia and cemented cataclastic fault breccia are present within that slope-wash alluvium 6 (pl. 1D, C14S) indicating the silicification of the brec- cias took place well before the formation of the veins and the subsequent deposition of the slope-wash alluvium.

In summary, episodes of faulting temporarily create open fractures in the veins and in the slope-wash alluvium. These fractures form conduits for percolating water and for fine-grained sediments. Movement of water within these fractures is enhanced after the sediments are cemented by carbonate and opaline silica and then are subsequently fractured. Surface runoff percolates through the near-vertical fractures and precipitates carbonate that forms laminae. Because the major fractures exposed in trench 14 occur at and near the bedrock-alluvium contact, the amount of water available for carbonate translocation is greater than on an isolated alluvial surface. The breccias adjacent to the near-vertical veins have been affected by the processes responsible for the precipitation of the secondary carbonate and opaline silica in the veins. The carbonate deposits in the veins within the bedrock and at the bedrock-alluvial contact may be, in part, considerably older than nearby calcic soils because the veins are more protected from the effects of erosion. This higher resistance to erosion results in a more stable surface and allows a longer period of carbonate accumulation.

\section{NATURE AND AGE OF FAULT DISPLACEMENTS EXPOSED IN TRENCH 14}

Multiple episodes of faulting or fracturing, or both, on the Bow Ridge Fault are indicated by the crosscutting exposed in trench 14. There are two phases of faulting, however, each phase may include more than one faulting event.

\section{Phases of Faulting}

\section{Phase One}

Phase one is defined as the formation of the fault breccias in trench 14. These breccias are exposed best in the center section of the south wall (pl. 1D, fig. 7). In trench 14A (fig. 3), phase one is indicated by the faulting of the Rainier Mesa Member of the Timber Mountain Tuff [age; 11.6 Ma (Sawyer and others, 1990)] against the upper lithophysal zone of the Tiva Canyon Member of the Paintbrush Tuff [age; 12.7 Ma (Sawyer and others, 1990)]. Although the Rainier Mesa Member is sometimes present in lateral depositional contact with the Tiva Canyon Member (Scott and Bonk, 1984), there is no evidence of this contact in trench 14A. 
Because the Rainier Mesa Member is part of the early fault phase, a maximum age of $11.6 \mathrm{Ma}$ is indicated for the phase one.

In trench 14 , the uncemented fault breccia (UFB), the silica-cemented fault breccia (SFB), the cataclastic fault breccia (CB), and probably the nonwelded fault breccia (NWB) were formed during this phase one. Near the center of the fault zone, cemented cataclastic fault breccia grades into the coarser silicacemented fault breccia to the east and west. These two types of breccia may represent separate episodes of faulting, but the gradational contact between the two indicates that they formed in one event. The contact between the silica-cemented fault breccia and the uncemented fault breccia also is gradational. As discussed in the unit descriptions, the silicification, in part, postdates this brecciation. The nonwelded fault breccia may have formed in a later event than the other breccias. The nonwelded fault breccia is not silicified, but contains clasts of broken opaline silica vein material and clasts of silicified nonwelded tuff (NWT), which indicates that the vein material was broken and reworked during a later faulting episode. Because the vertical veins that represent phase two in trench 14 crosscut the nonwelded fault breccia, the breccia needs to be included in phase one.

Because clasts of the lower part of the Tiva Canyon Member caprock were dragged down into the fault zone (pl. 1D, D15S), a vertical offset of several meters during the phase one is indicated.

\section{Phase Two}

Phase two is defined by the faulting associated with the formation of the carbonate and opaline silica veins that crosscut the breccias that formed in phase one. The irregular laminae in the veins probably represent multiple faulting episodes, rather than just continuous translocation and precipitation of carbonate and opaline silica through a disturbed zone or crack. The presence of laminae that consist entirely of fine-grained sediment, including laminae of black ash, indicates that actual fractures formed during faulting.

The colluvial wedges below the slope-wash alluvium (pl. 1B and 1D) cannot be correlated across the trench wall; they represent faulting episodes that predate the deposition of the slope-wash alluvium (unit 3 ). These events are preserved in the vertical veins, but no offset can be measured and no timing of faulting can be inferred.

The veins seem to penetrate and, therefore, postdate the colluvium and the deposition of the slope-wash alluvium (pls. 1B and 1D). Veins III and IV penetrate a coarse deposit that may be older or correlative with one of the colluvial wedges (pl. 1D, C14S, C15S, D16S). This possibly older deposit in unit 3 is indicated on the plates as $3 K m q$. Vein V, which is entirely in colluvium and slope-wash alluvium, could be younger than any of the preserved veins that penetrate the bedrock. It is not as large as the veins that penetrate the bedrock and does not contain the dense opaline silica stringers.

The near-vertical veins are capped by the platy $3 \mathrm{Kmql}$ horizon in unit 3, except for two veins that cut continuously through horizon $3 \mathrm{Km} q \mathrm{I}$. A $15-\mathrm{cm}$ wide vein that has vertical laminae and black ash in the central fracture, extends through the $3 K m q 1$ horizon exposed on the south wall (pl. 1D, lower center of B15S, upper center of C15S). On the north wall the $3 \mathrm{Kmql}$ horizon is crosscut by a $12.5-\mathrm{cm}$ wide vein that has vertical laminae (pl. 1B, top right of $\mathrm{C} 13 \mathrm{~N}$ ). Because most of the near-vertical veins are truncated by the platy $3 \mathrm{Kmq} 1$ horizon in unit 3 , either the veins (1) predate the formation of the plates, (2) the platy horizon is too pedogenically active to preserve the vertical veins, or (3) soil creep downslope has caused the platy horizon to be disrupted above the veins.

Phase two of the faulting also includes lowangle, west-dipping veins. These veins have a complex crosscutting relationship with the high-angle veins, and merge in places with the platy $3 \mathrm{Km} q \mathrm{I}$ and $3 \mathrm{Kmq} 2$ horizons. In some places, the complete width of a lowangle vein truncates the outer parts of a high-angle vein, but is crosscut by the inner vertical laminae (pl. 1B, bottom left of C13N, left center of D14N; pl. 1D, bottom left of D15S, bottom right of C14S, top right of D14S). In other places, a low-angle vein is mostly truncated at the outer edge of a high-angle vein, but some of its laminae continue and crosscut all vertical laminae (pl. 1B, bottom center of C14N; pl. 1D, top right of C14S, bottom left C14S). Because of the crosscutting relations within the veins, phase two represents multiple faulting events.

Phase two also includes one of the most recent fracturing events, which cuts unit 2 and the platy $3 \mathrm{Kmql}$ horizon in unit 3. These fractures, including the fractures west of the main fault, appear to contain the black magnetic ash (fractures 1-3 on pl. 1E and fractures 4-6 on pl. 1F).

The black ash (see discussion of the age of the black ash in the "Vein Filling" section) is the younger ash from the Lathrop Wells because:

1. The uppermost part of the platy $3 \mathrm{Kmql}$ horizon has a U-series age of $88 \pm 5 \mathrm{ka}$ (table 4 ). This horizon has obviously been fractured, and the black ash is preserved in the vertical fractures and adjacent carbonate cement. 
2. The well-developed platy $3 K m q l$ horizon within unit 3 was already in place at the time of fracturing, and the time to develop a platy $K$ horizon in the Yucca Mountain region is a minimum of 300,000 years (Taylor, 1986).

3. Ash disseminated in the $2 B t j$ horizon (unit 2) above the ash-filled fractures indicates that the reworked ash may be younger than the $2 B t j$ horizon which is dated at $38 \pm 10$ and $55 \pm 20 \mathrm{ka}$ (table 4).

Because fractures in the slope-wash alluvium are unlikely to remain open for long periods of time and because of the relative purity of the black ash in some fractures, the fracturing event was probably contemporaneous with an ash eruption. The black ash probably washed into the open fractures as well as being derived from the air-fall. This sequence of events would indicate that the fracturing occurred between 15,000 and 130,000 years ago.

The ash-filled fractures in trench 14 are within the vein laminae and commonly, but not universally, cut most plates in unit 3 . There are a few exceptions where the upper carbonate-cemented plates in unit 3 do not appear to be cut (pl. 1D, bottom left of B14S, upper right of E31S). Possibly, movement of plates downslope, within the $3 \mathrm{Kqm} I$ horizon, near the top of unit 3 could have obscured fracturing in those layers.

The prismatic soil structure of the $2 B t j$ horizon in unit 2 (table 2) makes it difficult to determine if the ashfilled fractures penetrate the horizon. Soils that have prismatic structures heal very rapidly if disrupted, preserving vertical prism faces that are extremely difficult to distinguish in the field from tectonic fractures. However, there is evidence that the fractures do, in fact, extend into this unit. In addition to the presence of the black ash, a fracture shown on plate 1D, coordinate $B 17 S$, extends above the carbonate vein into unit 2 , as indicated by rotated pebbles preserved along the trend of the fracture.

No marker horizons are present below the platy $3 \mathrm{Kmql}$ horizon, which overlies the main fault zone, to indicate the offset that occurred during phase two. A strike-slip component of movement cannot be ruled out.

\section{Other Tectonic Features Exposed in Trench 14}

Interesting features on the south wall of trench 14 include curving open fractures (pl. 1D, D16S-E16S), the lower two of which trace into carbonate-filled fractures (oriented $\mathrm{N} 40^{\circ} \mathrm{E}$ ) crosscutting the silica- cemented fault breccia (SFB). The uppermost fracture traces to a fracture face in the silica-cemented fault breccia coated with botryoidal quartz. A rotated clast (indicated by vertically oriented opaline silica coating on one side and none on the bottom) is wedged between the top and the middle fractures. High-angle stringers from the east truncate a low-angle carbonate stringer from the west. In general, high-angle features seem younger than low-angle features.

Another interesting feature is a low-angle open fracture about $25 \mathrm{~cm}$ wide (pl. 1D, D17S, E18S). It is possibly an east-dipping fault that has about $9 \mathrm{~cm}$ of reversed offset, as determined by matching two wellcemented fine-grained zones that are capped by carbonate stringers (pl. 1E, D19S, E19S). Another lowangle, east-dipping possible fault is filled with ooidic carbonate and traces into a possible filled animal burrow to the west (pl. 1D, E18S; pl. 1E, E19S, bottom of D20S-D21S). The possible fault also traces to the east into an open fracture lined with brecciated carbonate, possibly indicating repeated movement.

A carbonate fracture filling, parallel to the trench face (pl.1C, A1S, labeled VF), has near-vertical slickensides. This carbonate yielded a $U$-series age beyond the resolution of the method $(>450 \mathrm{ka})$.

Two general azimuth orientations are observed in trench 14. About 85 percent of the bedrock fractures are oriented northwest; the remainder are oriented northeast. All fractures in the slope-wash alluvium are oriented northeast (table 6, fig. 13). The dominant fracture orientation in the bedrock is probably that of cooling joints, which are characterized by being closely spaced and parallel (pl. 1C, D10S-D11S). These nested cooling joints trend northwest and, compared to the dominant northeast trend in the younger alluvial deposits, probably indicate a change in the stress orientation. The bedrock fractures that do not trench northwest do coincide with the northeast trend preserved in the slope-wash alluvium (fig. 13).

\section{Discussion of Evidence of Faulting Exposed in Trench 14}

Major faulting occurred shortly after the deposition of the Tiva Canyon Member bedrock [age; 12.7 Ma (Sawyer and others, 1990)]. Several meters of offset are indicated, and the dominant orientation of this early fracturing was to the northwest. Prior to the deposition of unit $3(480 \pm 90 \mathrm{ka}$ ) (table 4), two colluvial wedges were deposited against fault scarps that were later beveled by erosion. No offset can be measured, and no timing of faulting can be inferred from these colluvial wedges, but they reflect two major fault- 
Table 6. Orientations of the fractures in the slope-wash alluvium exposed on the north and south walls of trench 14

[Fractures are shown on plates 1E and 1F. South wall locations are actual grid locations on the south wall. North wall locations are correlative grid locations on the unmapped section of the north wall. Locations were measured from the last or westernmost vertical grid line on the north wall. Strikes were measured off the trend of matching fractures on the north and south walls. NA, not available]

\begin{tabular}{cccccc}
\hline \multirow{2}{*}{$\begin{array}{c}\text { Fracture } \\
\text { number }\end{array}$} & \multicolumn{2}{c}{ Location } & Azimuth & \multicolumn{2}{c}{ Dip } \\
\cline { 2 - 3 } \cline { 5 - 6 } orientation & South wall & North wall & South wall & North wall \\
\hline 1 & $27 \mathrm{~S}$ & $23 \mathrm{~N}$ & $40^{\circ}$ & $84^{\circ} \mathrm{E}$ & $87^{\circ}$ \\
2 & $31 \mathrm{~S}$ & $28 \mathrm{~N}$ & $32^{\circ}$ & $85^{\circ} \mathrm{E}$ & $80^{\circ} \mathrm{E}$ \\
& & & & & $79^{\circ} \mathrm{W}$ \\
3 & $31 \mathrm{~S}$ & $28 \mathrm{~N}$ & $34^{\circ}$ & $80^{\circ} \mathrm{E}$ & $74^{\circ} \mathrm{E}$ \\
4 & $47 \mathrm{~S}$ & $43 \mathrm{~N}$ & $35^{\circ}$ & $84^{\circ} \mathrm{E}$ & $85^{\circ} \mathrm{E}$ \\
& & & & $81^{\circ} \mathrm{W}$ & \\
5 & $47 \mathrm{~S}$ & $43 \mathrm{~N}$ & $35^{\circ}$ & $N \mathrm{~N}$ & $89^{\circ} \mathrm{E}$ \\
6 & $54 \mathrm{~S}$ & $51 \mathrm{~N}$ & $30^{\circ}$ & $82^{\circ} \mathrm{E}$ & $86^{\circ} \mathrm{E}$ \\
\hline
\end{tabular}

ing episodes. Sometime after the deposition of unit 3 and before the formation of the maximally developed $K m q 1$ horizon which caps unit 3 ( $88 \pm 5 \mathrm{ka}$ ) (table 4), two or more fracturing or faulting events occurred. After the formation of the $K m q$ horizons, and probably after the deposition of unit $2(38 \pm 10 \mathrm{ka})$ (table 4$)$, fractures formed and were filled with a black ash. This ash is probably of late Pleistocene age. If the U-trend age of $480 \pm 90 \mathrm{ka}$ (table 4) is correct for unit 3 and, if at least three fracturing or faulting events have occurred since the accumulation of the slope-wash alluvium, an average maximum recurrence interval on the order of 150,000 years can be inferred.

\section{DESCRIPTION OF THE LITHOLOGIC UNITS EXPOSED IN TRENCH 14D}

Trench 14D (figs. 3 and 14) was excavated to evaluate the physical characteristics of faulted depositional units and soils that are not immediately adjacent to a bedrock-alluvial contact. Trench 14D exposes six Quaternary depositional units buried by a seventh unit, a thin vesicular $A$ horizon. The depositional history, formation of soil horizons, and faulting events are recorded in the exposed units (fig. 15). The trench exposes three faulting events and periods of deposition. With depth, there is progressively greater offset of the depositional units (fig. 14).

There are six distinct lithologic units exposed in trench 14D-units 1D through 6D. These units include depositional units consisting of slope-wash alluvium, channel alluvium, and colluvium, and the soils devel- oped on them. Ten soil horizons have been distinguished.

Unit 1D

Unit 1D is a light brown gray (10YR 6.5/2), slightly hard, gravelly silty sand. Unit $1 \mathrm{D}$ is eolian in nature, based on the uniform sorting and the lack of coarse gravel. There is no visible secondary carbonate. This unit is correlated with latest Holocene deposits within the Yucca Mountain area (Taylor, 1986). Within unit $1 \mathrm{D}$, there is a single soil horizon.

The $A v$ horizon is a light brown gray (10YR $6.5 / 2$, dry) to dark brown (10YR 4/3, moist); slightly hard, moderately sorted, silty sand (soil texture: sandy loam), that has less than 5 percent pebble gravel. The basal horizon boundary is abrupt, and the $A v$ horizon thickness ranges from less than 4 to $12 \mathrm{~cm}$.

\section{Unit 2D}

Unit 2D is a pale brown (10YR 6-6.5/3), soft to slightly hard, gravelly silty sand; and contains from less than 10 to 60 percent subangular pebble-cobble gravel. Unit 2D is capped by a thin buried eolian soil horizon, but is primarily slope-wash alluvium.

Unit 2D is probably correlative in age to unit Q1c described by Hoover and others (1981) and by Taylor (1986), and unit 1 in trench 14, based on the physical 
@ A

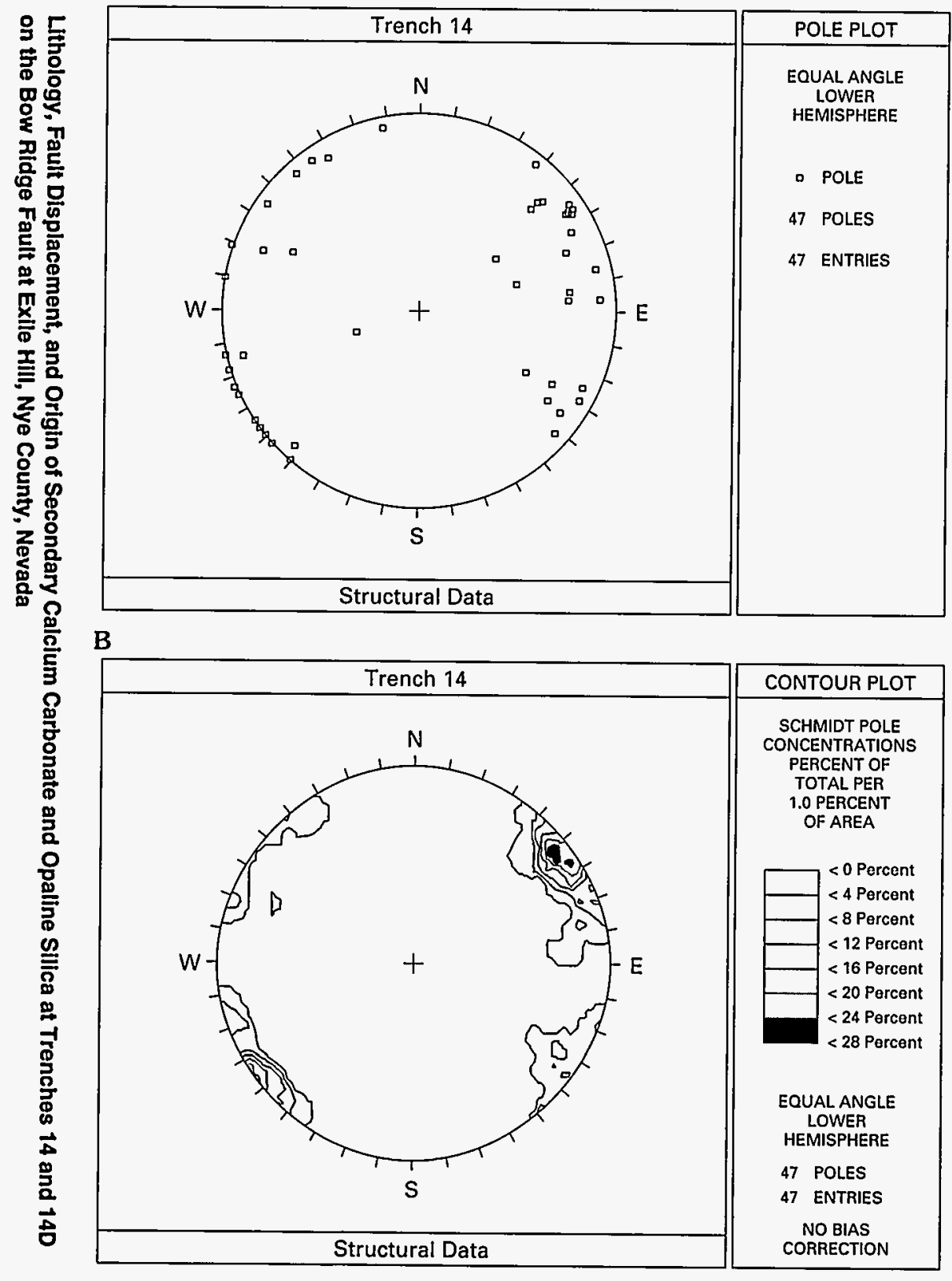

BEDROCK
C

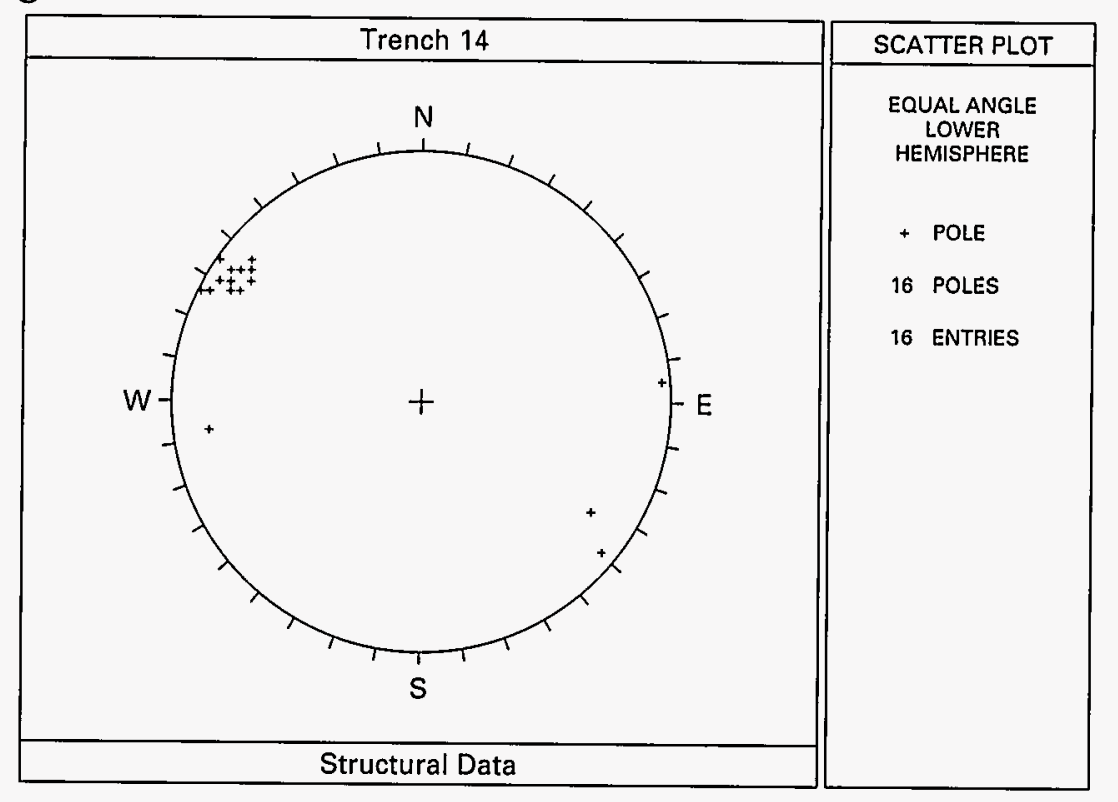

D

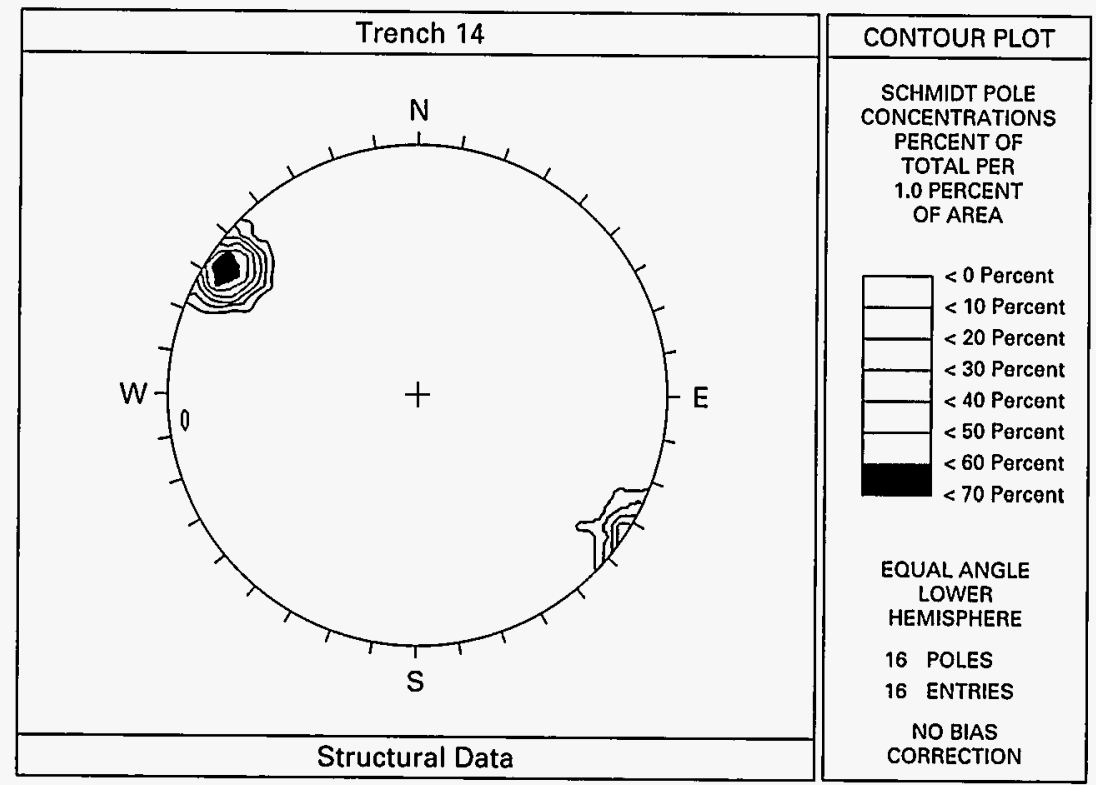

SLOPE-WASH ALLUVIUM Figure 13. Stereonet projection showing compilation and comparison of fracture orientations in the bedrock (A and $B$ ) and slope-wash alluvium (C and D)
exposed in trench 14. 


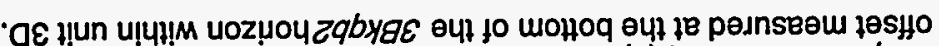

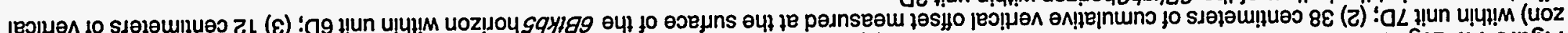
(e) : -

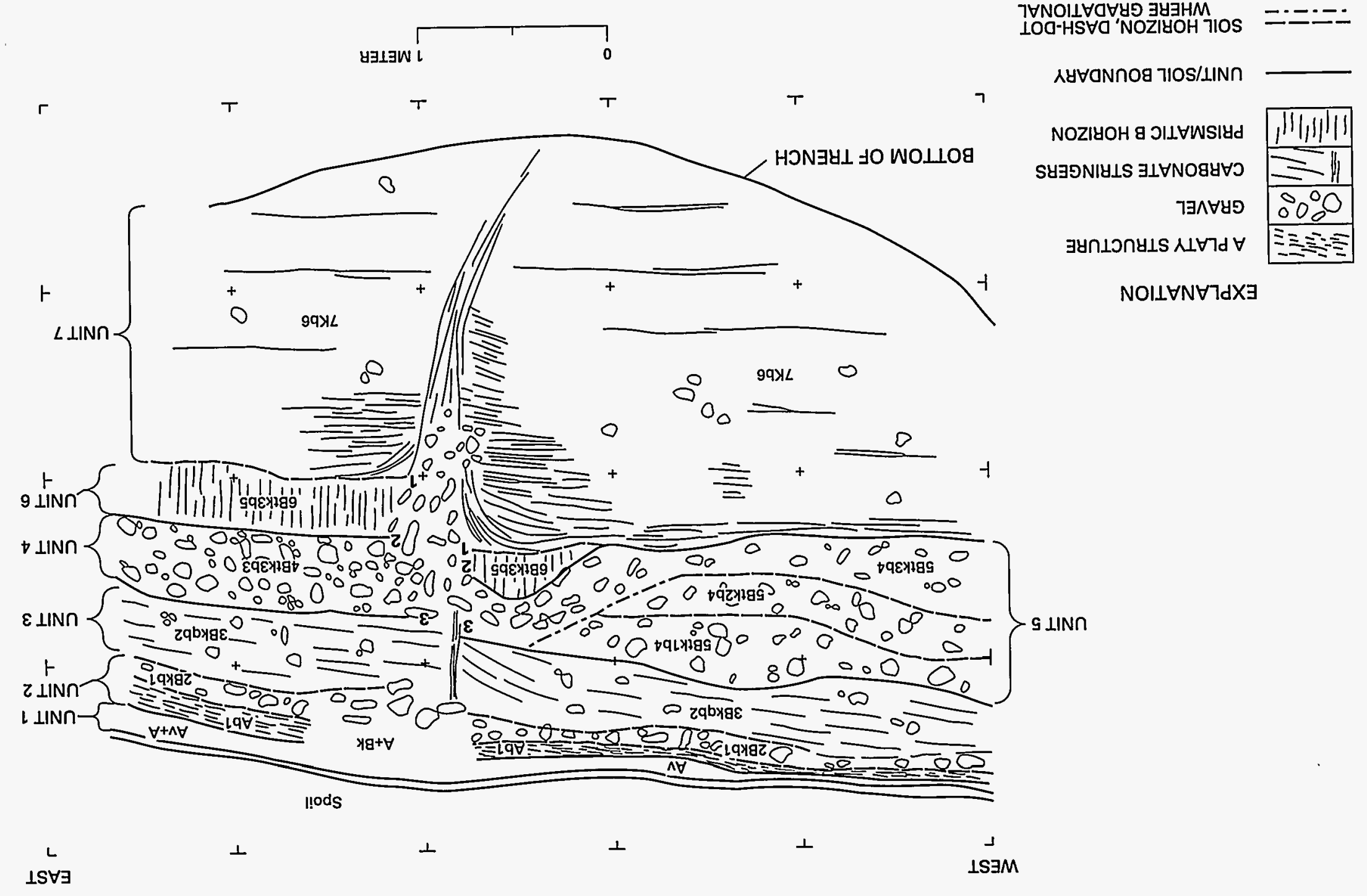

$\perp S \forall \exists$ 

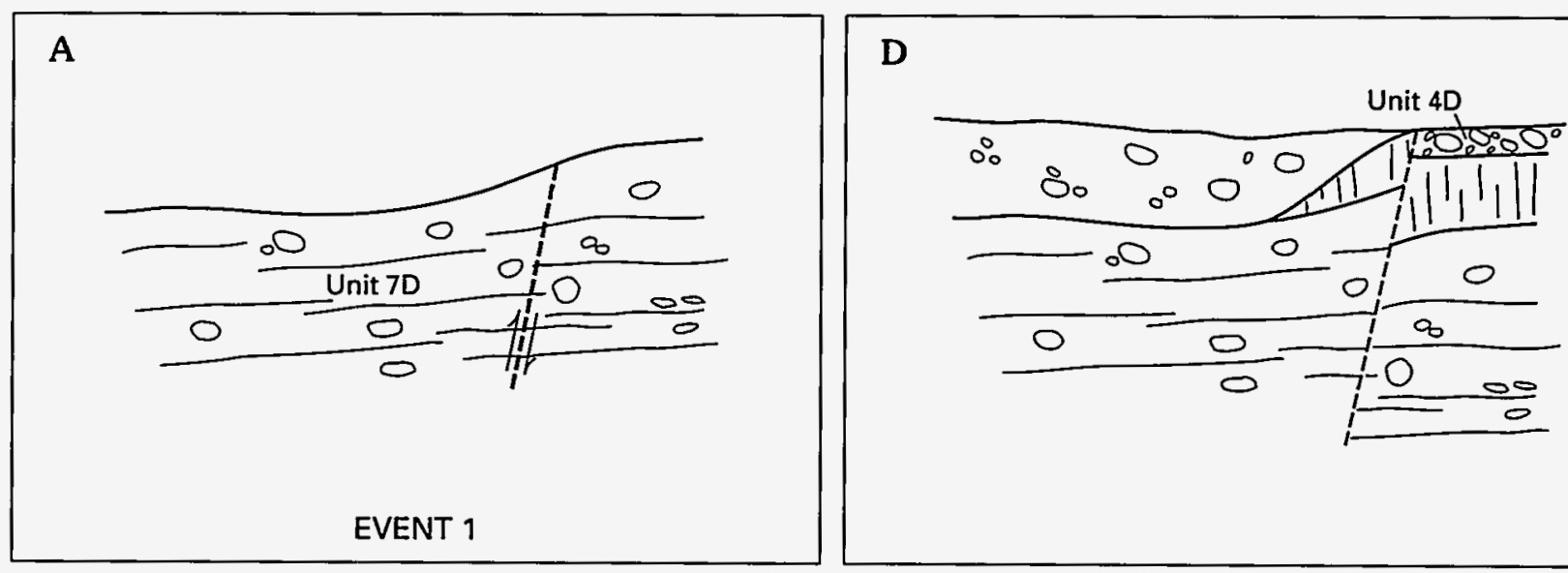

B
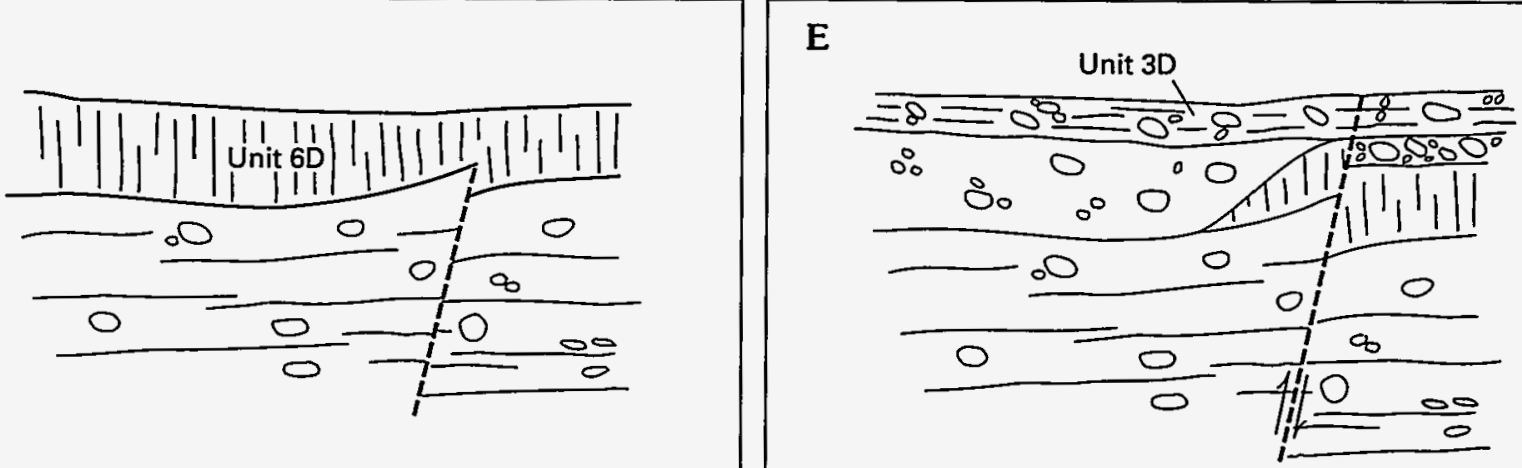

EVENT 3

C

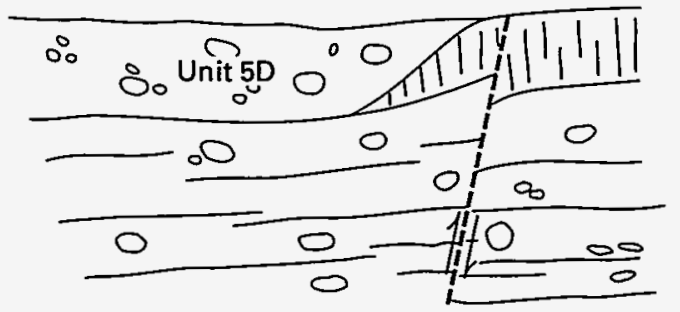

EVENT 2

\section{F}

Unit $1 \mathrm{D}-$

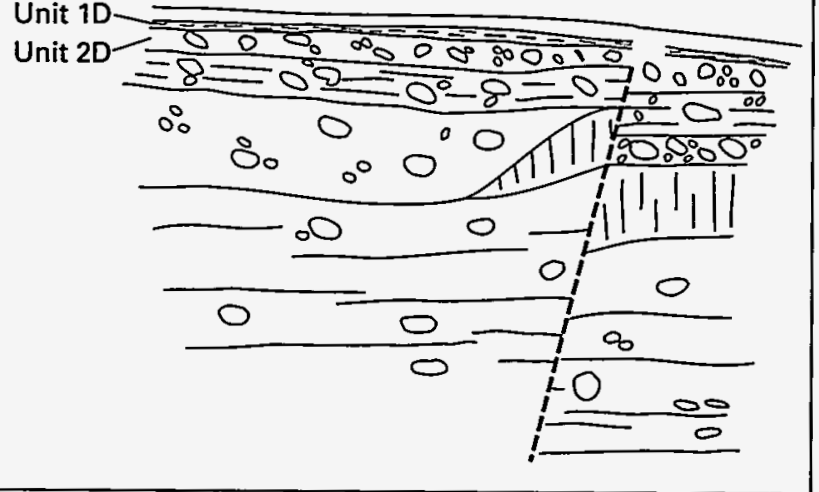

Figure 15. Proposed sequential development of the fault and the surficial deposits exposed on the south wall of trench 14D. Other soil horizons were probably present but have been eroded and are not exposed in trench 14D. Vertical lines represent structural $B$ thorizon development. Horizontal stringers represent secondary carbonate accumulation. in the buried $A$ horizon $(A B)$, the stringers represent a thin platy structure. Units 1D-7D are the same as those in figure 14. There is no scale. $\mathrm{A}$, Pre-fault configuration showing the fault location and soil developed on the surface of unit $7 \mathrm{D}$. B, Proposed configuration after the first faulting event and deposition of a fine-grained slope-wash alluvium (unit 6D). Vertical offset was approximately 13 centimeters. Fault filling from this first event occurs at a lower angle in unit $6 D$ than fault filling derived from later events. C, Deposition of alluvium in a channel adjacent to the existing fault zone (unit 5D). D, Proposed configuration after the second faulting event and deposition of a thin wedge of colluvium (unit 4D). Vertical offset was approximately 26 centimeters. Unit 4D pinches out about 4 meters downslope and west of the fault zone exposed in trench 14D. E, Deposition of slope-wash alluvium (unit $3 \mathrm{D}$ ) over units $4 \mathrm{D}$ and $5 \mathrm{D}$, prior to the third faulting event. F, Proposed configuration after the third faulting event. Vertical offset was approximately 12 centimeters. Units 1D and 2D were deposited over the fractured unit 3D, and if they were involved in the third faulting event, it cannot be determined. 
characteristics of the soil. The dominant characteristic is a weak carbonate accumulation on the underside of gravel clasts. This unit is correlated with similar deposits in the Yucca Mountain region which are dated or inferred to be of late Pleistocene to early Holocene age (Taylor, 1986). Within unit 2D, there are two discrete soil horizons.

The $A b 1$ horizon is a pale brown (10YR 6/3, dry) to dark brown (10YR 4/3, moist), soft, silty sand (soil texture: sandy loam) that has less than 10 percent pebble gravel. The soil structure is strongly developed thin plates. The basal horizon boundary is abrupt, and the $A b 1$ horizon thickness ranges from 5 to $17 \mathrm{~cm}$.

The $2 B k b 1$ horizon is a pale brown (10YR 6$6.5 / 3$, dry) to yellowish-brown (10YR 5/4, moist), soft to slightly hard, silty sand (soil texture: sandy loam) that has 60 percent pebble-cobble gravel. Clasts within the gravel range from 6 to $10 \mathrm{~cm}$. The secondary carbonate forms thin to thick coatings on the underside of pebbles with some bridging (stage I-II). The basal horizon contact is abrupt, and the $2 B k b l$ horizon thickness ranges from 5 to $17 \mathrm{~cm}$. Unit thins and wedges out west of mapped exposure.

\section{Unit 3D}

Unit 3D is a light-yellowish-brown (10YR 6/3-4), compact, gravelly sandy silt; and contains less than 10 percent subangular pebble-cobble gravel. The unit is characterized by a soil horizon that has indurated plates as long as $30 \mathrm{~cm}$, which are cemented by secondary carbonate (stage $\mathrm{I}$ ) and opaline silica (stage 3 ). Unit 3D is slope-wash alluvium.

Unit 3D is probably correlative in age to unit Q2b described by Hoover and others (1981) and by Taylor (1986), based on the physical characteristics of the soil. The dominant characteristic is the thickness and degree of development of the opaline silicacemented horizon. Unit $\mathrm{Q} 2 \mathrm{~b}$ varies in age from 145 to $190 \mathrm{ka}$ (Rosholt and others, 1985). Within unit 3D, there is a single preserved soil horizon.

$3 B k q b 2$ light-yellowish-brown (10YR 6/4, dry) to dark-yellowish-brown (10YR 4/4, moist), extremely hard, sandy silt (soil texture: loamy sand) that has less than 10 percent pebble-cobble gravel. White secondary carbonate (7.5YR-10YR $8 / 0$, stage I) and pinkish- opaline-silica (7.5YR, stage 3 ) cement forms very coarse discrete plates. Carbonate stringers are parallel to the vertical fracture (fig. 14). The basal horizon contact is abrupt, and the $3 B k q b 2$ horizon thickness ranges from 24 to $40 \mathrm{~cm}$.

\section{Unit 4D}

Unit 4D is a strong brown (7.5YR 5.5/4), compact, gravelly sandy silt to sand; and contains from 70 to 80 percent poorly sorted, angular to subangular pebble-cobble gravel. Unit 4D is a colluvial wedge only present on the west side of the exposed fault, and probably derived in part from unit 5D. Within unit 4D, there is a single preserved soil horizon.

The $4 B t k 63$ horizon is strong brown (7.5YR $5.5 / 4$, dry) to brown (7.5YR 5/5, moist), hard to extremely hard, sandy silt to sand (soil texture: sandy loam to sand) that has 70-80 percent pebblecobble gravel. Secondary carbonate coats the underside of gravel clasts, and there is some bridging (stage I-II). A few moderately thick clay films are present on ped faces. The basal horizon boundary is gradual, and the $4 B t k 63$ horizon thickness ranges from 30 to $40 \mathrm{~cm}$.

\section{Unit 5D}

Unit 5D is a brown- to yellowish-brown (7.5YR10YR), compact, gravelly sandy silt to sand; and contains from 50 to 60 percent poorly sorted, and angular to subangular pebble-cobble gravel. Unit 5D is derived from alluvium that was deposited in a channel adjacent to the fault. It is only present on the east side of the exposed fault. Within unit 5D, there are three discrete soil horizons.

The $5 B t k 1 b 4$ horizon is a reddish-yellow (7.5YR $6 / 6$, dry) to strong brown (7.5YR 5/6, moist), hard to extremely hard, silty sand (soil texture: sandy loam) that has from 50 to 60 percent pebble-cobble gravel. The uppermost part of the horizon has a thin platy structure. Secondary carbonate thinly and irregularly coats the underside of gravel clasts (stage I). Moderately thick- to thick-clay films are present on ped faces. The basal contact is gradational, and the horizon thickness ranges from 18 to $38 \mathrm{~cm}$.

The $5 B t k 2 b 4$ horizon is light brown to lightyellowish-brown (7.5YR-10YR 6-7/4, dry) to brown (7.5YR 5/4, moist), extremely hard, silty sand (soil texture: sandy loam) that has from 50 to 60 percent pebble-cobble gravel. Secondary carbonate coats the underside of gravel clasts and forms bridges between clasts (stage II). Moderately thick clay films are present on ped faces. The 
basal contact is gradational, and the $5 B t k 2 b 4$ horizon thickness ranges from 20 to $25 \mathrm{~cm}$.

The $5 B t k 3 b 4$ horizon is light brown (7.5YR $6.5 / 4$, dry) to dark brown (7.5YR 4/4, moist), hard to extremely hard, silty sand (soil texture: loamy sand) that has from 50 to 60 percent pebble-cobble gravel. Secondary carbonate coats the underside of gravel clasts and forms bridges between the clasts (stage II) and continuous well-cemented stringers (stage III). The basal contact is abrupt, and the $5 B t k 3 b 4$ horizon thickness ranges from 15 to $43 \mathrm{~cm}$.

\section{Unit 6D}

Unit 6D is a brown- to yellowish-brown (7.5YR10YR) silty sand. It contains less than 5 percent moderately well-sorted and subangular pebble-cobble gravel. Unit 6D is slope-wash alluvium and although it is similar to unit 2 exposed in trench 14, it is probably not correlative based on its stratigraphic position. Within unit $6 \mathrm{D}$, there is one discrete soil horizon.

The $6 B t k b 5$ horizon is pink to very pale brown (7.5YR-10YR 7/4, dry) to brown (7.5YR 5/4, moist), hard to extremely hard, silty sand (soil texture: loamy sand) that has less than 5 percent pebble-cobble gravel. Secondary carbonate coats ped faces and, in places, coats the underside of gravel clasts, there is some bridging between clasts (stages I-II). The horizon has a distinctive prismatic soil structure, and is best preserved on the west side of fault, but a small part is preserved on the east side immediately adjacent to the fault. The basal horizon contact is abrupt, and the $6 \mathrm{Btkb5}$ horizon thickness ranges from 30 to $35 \mathrm{~cm}$.

\section{Unit 7D}

Unit 7D is a very pale brown (7.5YR) with white carbonate (10YR 8/0), gravelly sand. It contains less than 10 percent moderately well-sorted and subangular pebble-cobble gravel. Unit 7D is slope-wash alluvium and probably correlates in age with unit 3 exposed in trench 14. Hoover and others, (1981) correlated unit 3 to a unit that is $<730 \mathrm{ka}$; more recently, Swadley and others (1984) and Rosholt and others (1985) determined the age to be between $270 \pm 90$ and $480 \pm 90 \mathrm{ka}$ (table 4). Within unit 7D, there is one discrete soil horizon.

The $7 \mathrm{~kb} 6$ horizon is very pale brown (7.5YR 7/4, dry), white carbonate (10YR $8 / 0$ ), loose to extremely hard, sand that has less than 10 percent pebble-cobble gravel. Secondary carbonate forms continuous dense stringers as wide as $10 \mathrm{~cm}$ (stage III). Carbonate stringers dip into and are adjacent to the fault. The basal horizon contact and thickness are unknown.

\section{NATURE AND AGE OF FAULT DISPLACEMENTS EXPOSED IN TRENCH 14D}

\section{Event One}

The stratigraphically lowest and oldest deposit exposed in trench 14D, unit 7D (fig. 15A), is a finegrained slope-wash alluvium that correlates to unit 3 in trench 14. Unit 7D appears to have been faulted prior to the deposition of unit $6 \mathrm{D}$. There is a low angle fault filling, within unit $7 \mathrm{D}$, that is not related to later nearvertical offset. On the basis of (1) the estimated age of unit 7D, and (2) the age of unit 3D, discussed in the "Event Three" section, the first faulting event occurred with vertical movement down to the west of 13 centimeters, sometime between about 145,000 and 270,000 years ago.

Unit $6 \mathrm{D}$ was deposited over the faulted surface (fig. 15B). A soil formed at the surface that is characterized by a $B t$ horizon, or clay-rich horizon, that is morphologically distinguished from the carbonateenriched zone, or $K$ horizon, developed on unit 7D (table 7).

The relative positions of the horizon of silicate clay accumulation $(B t)$ to the horizon of carbonate accumulation $(B k$ or $K$ ), within a single unit or units that were deposited within a very short period of time, is an important clue in identifying periods of subareal exposure and soil formation, and thus faulting events. Clay-rich horizons tend to be present above carbonaterich horizons in a single soil sequence. Clay originates by weathering of the parent material or from illuviation-the downward movement of, in this case, clay in suspension from a zone where the clays were formed or deposited (Birkeland, 1984). Therefore, clay tends to be deposited at the base of the zone that is wetted by water movement rapid enough to maintain the clay in suspension. Calcium bicarbonate, when in solution rather than in suspension, would be expected to move deeper than the clay and to precipitate (as calcium carbonate) below the clay as the soil solution dries. Secondary carbonate accumulations tend to record the maximum wetting depths.

Clay migration requires that the clay be dispersed so that it can remain in suspension and be transported by water moving slowly through pores or cracks 
Table 7. Dominant physical characteristics and percentages of calcium carbonate in the deposits exposed in trench 14D

[Units and soil horizons are shown in figure 14. Textual classes (based on grain size analyses)—SL, sandy loam; LS, loamy sand; S, sand. Structure- (1) Grade-1, weak; 2, moderate; 3, strong; (2) Strength- $\mathrm{n}$, thin or very fine; $\mathrm{f}$, fine; $m$, medium, co, coarse; vco, very coarse; and (3) Kind—sbk, subangular blocky; pr, prismatic; pl, platy; abk, angular blocky. Dry consistence-lo, loose; so, soft, sh, slightly hard; $h$, hard; eh, extremely hard. Clay films-(1) Frequency-1, few; (2) thickness-mk, moderately thick; $k$, thick; (3) location-pf, ped face. \%, percent; <, less than; >, greater than; $\mathrm{cm}$, centimeter; $\mathrm{m}$, meter; dashes $(-)$, no data]

\begin{tabular}{|c|c|c|c|c|c|c|c|c|c|c|c|c|c|c|c|}
\hline \multirow{2}{*}{$\begin{array}{l}\text { Soll } \\
\text { HZN }\end{array}$} & \multirow{2}{*}{$\begin{array}{l}\text { Thick- } \\
\text { ness } \\
\text { CM }\end{array}$} & \multicolumn{2}{|c|}{ Color } & \multicolumn{3}{|c|}{ Percent } & \multirow{2}{*}{$\begin{array}{l}\text { Tex- } \\
\text { ture }\end{array}$} & \multirow{2}{*}{ Structure } & \multirow{2}{*}{$\begin{array}{l}\text { Dry } \\
\text { con }\end{array}$} & \multirow{2}{*}{$\begin{array}{l}\text { Clay } \\
\text { fllms }\end{array}$} & \multicolumn{2}{|c|}{$\mathrm{CaCO}^{3}$} & \multirow{2}{*}{$\begin{array}{l}\text { Gravel } \\
\text { percent }\end{array}$} & \multirow{2}{*}{$\begin{array}{l}\text { Parent } \\
\text { materlal }\end{array}$} & \multirow{2}{*}{$\begin{array}{l}\text { Miscella- } \\
\text { neous }\end{array}$} \\
\hline & & Dry & Moist & Sand & silt & Clay & & & & & Stage & $\begin{array}{l}\text { Per- } \\
\text { cent }\end{array}$ & & & \\
\hline & & & & & & & & Unit 1D & & & & & & & \\
\hline \multirow[t]{2}{*}{ Av } & $4-12$ & $10 \mathrm{YR} 6.5 / 2$ & $10 \mathrm{YR} 4 / 3$ & -- & - & -- & SL & $2 \mathrm{~m}-\mathrm{cos} \mathrm{sbk}$ & sh & 0 & 0 & 0 & $<5$ & eolian & $\begin{array}{l}\text { best pre- } \\
\text { served on } E \\
\text { side of faulh } \\
\text { disturbed in } \\
\text { fracture zone }\end{array}$ \\
\hline & & & & & & & & Unit 2D & & & & & & & \\
\hline $\mathrm{Abl}$ & $5-17$ & $10 \mathrm{YR} 6 / 3$ & $10 \mathrm{YR} 4 / 3$ & -- & - & - & SL & $3 \mathrm{n} \mathrm{pl}$ & so-sh & 0 & 0 & 0 & $<10$ & eolian & $\begin{array}{l}\text { dominantly } \\
\text { roots, thick- } \\
\text { ens down } \\
\text { slope on west }\end{array}$ \\
\hline \multirow[t]{2}{*}{$2 \mathrm{Bkbl}$} & $5-17$ & 10YR $6.5 / 3$ & $10 \mathrm{YR} 5 / 4$ & 66.5 & 23.0 & 9.9 & SL & f sbk & so & 0 & I-II & 1.42 & 60 & $\begin{array}{l}\text { slope-wash } \\
\text { alluvium }\end{array}$ & $\begin{array}{l}\text { weakly } \\
\text { cemented, } \\
\text { dominantly } \\
\text { gravel clasts } \\
6-10 \mathrm{~cm} \text {, } \\
\text { thins and dis- } \\
\text { appears } \\
\text { downslope }\end{array}$ \\
\hline & & & & & & & & Unit 3D & & & & & & & \\
\hline \multirow[t]{2}{*}{ 3Bkqb2 } & $25-4$ & $\begin{array}{l}\text { 10YR 6/4 } \\
7.5 Y R- \\
10 Y R 8 / 0 \\
\text { (carb) }\end{array}$ & $10 \mathrm{YR} 4 / 4$ & 77.7 & 17.0 & 5.0 & LS & $\begin{array}{c}2-3 \text { vco pl; } \\
\text { vco sbk }\end{array}$ & eh & 0 & I & 1.90 & $<10$ & $\begin{array}{l}\text { slope-wash } \\
\text { alluvium }\end{array}$ & $\begin{array}{c}\text { few Mn stains } \\
\text { on ped faces, } \\
\text { Stage } 3 \text { silica } \\
\text { cementation? }\end{array}$ \\
\hline & & & & & & & & Unit 4D & & & & & & & \\
\hline $\begin{array}{l}\text { 4Btkb3 (W } \\
\text { side of fault) }\end{array}$ & $30-40$ & 7.5 YR $5.5 / 4$ & 6.5 YR $5 / 5$ & 84.6 & 11.4 & 4.0 & LS-S & f-m abk-sbk & h-eh & $1 \mathrm{mk}$ pf & I-II & 0.30 & $70-80$ & $\begin{array}{l}\text { colluvial } \\
\text { wedge }\end{array}$ & $\begin{array}{l}\text { Mn stains on } \\
\text { gravel \& ped } \\
\text { face, mod } \\
\text { well sorted, } \\
\text { poorly bed- } \\
\text { ded, thins } \\
\text { and disap- } \\
\text { pears W in } \\
\text { approx. } \\
4 \mathrm{~m}\end{array}$ \\
\hline
\end{tabular}


⿷匚 Table 7. Dominant physical characteristics and percentages of calcium carbonate in the deposits exposed in trench 14D --Continued

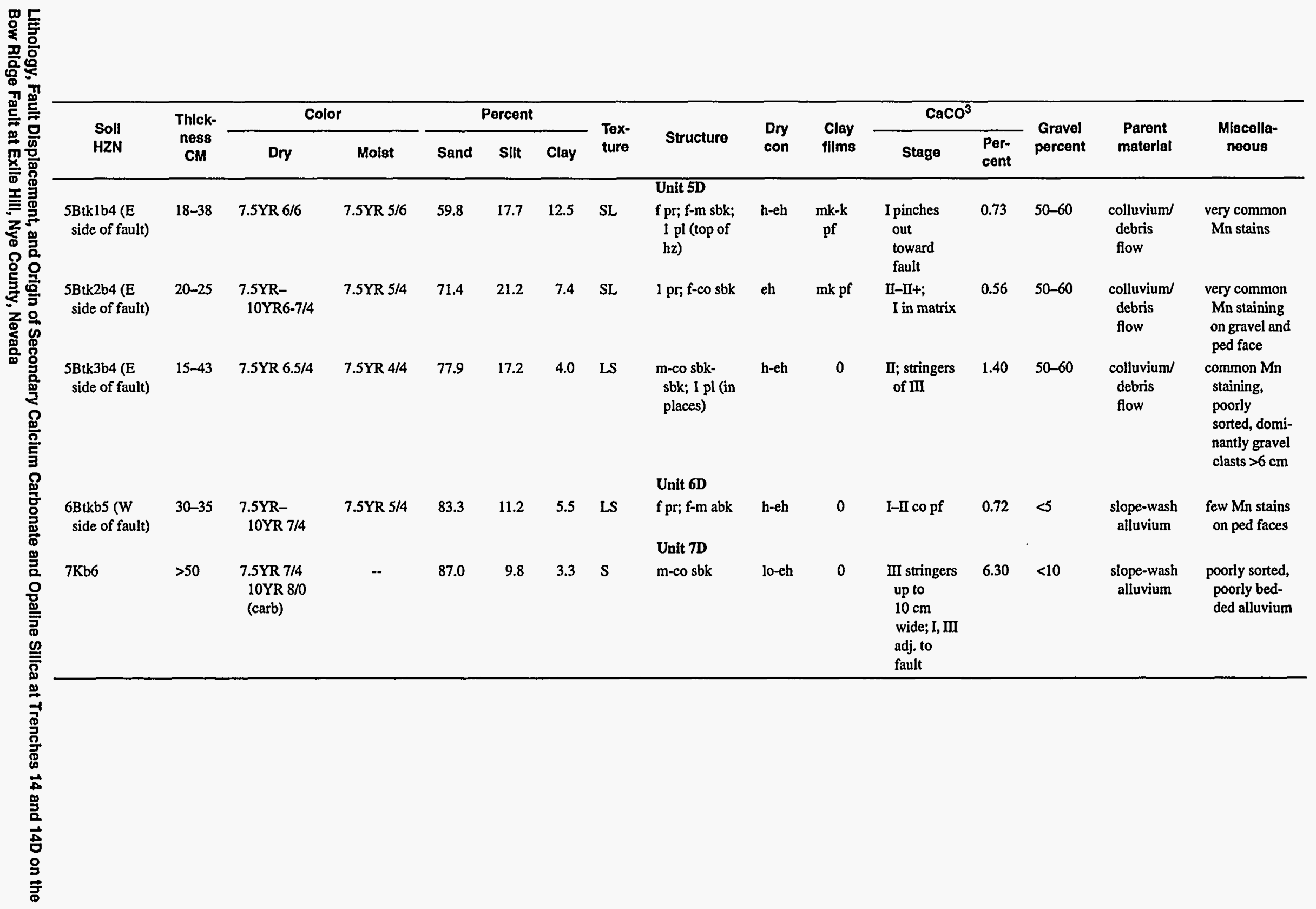


in the soil. In the presence of calcium carbonate, clay tends to flocculate and, under these conditions, clay cannot migrate. Soil horizons high in calcium carbonate tend to show little evidence of clay migration.

The basal slope-wash alluvial unit in trench 14 (unit 3) is correlated with unit 7D in trench 14D on the basis of similarity in physical soil characteristics (tables 2, 3, and 7). This soil appears to have been eroded down to the resistant $K$ horizon, prior to the deposition of unit 2 in trench 14 (table 2) and unit 6D in trench 14D. Differences between the basal units in trench 14 and 14D are summarized below:

The zone of maximum carbonate accumulation in unit 3 in trench 14 has a platy structure and has considerably more secondary carbonate-from 24 to 56 percent compared to 6 percent in trench 14D (tables 3 and 7). With continued carbonate accumulation, most or all pores become filled by carbonate, primary grains are forced apart, bulk density increases, and the infiltration rate decreases markedly. This process results in a plugged horizon, which develops in the last part of stage III carbonate morphology (Gile and others, 1981). Stage III is observed below the platy horizon in trench 14 and in the basal unit exposed in trench 14D (tables 2 and 7). After development of the plugged horizon, a laminar horizon forms on top of it. Infiltrating water concentrates at the top of the carbonate-plugged horizon, carbonate is deposited as the water evaporates, and laminae form.

The difference in the concentration and morphology of the secondary carbonate may be because (1) the proximity of the slope-wash alluvium to the bedrock scarp in trench 14, has increased the available moisture and dissolved carbonate locally or (2) the carbonateenriched zone in trench 14 has remained within the wetting front and has not been buried below the wetting front as it may have been in trench 14D.

\section{Event Two}

After the stabilization of unit 6D in trench 14D, an eastwardly inclined wedge of alluvium (unit 5D) was deposited in a channel across the fault zone (fig. 15C). The channel eroded and removed unit 6D east of the fault zone, although a small wedge of unit $6 \mathrm{D}$ is preserved adjacent to the fault zone (fig. 14). Unit 5D must have been deposited prior to faulting event two because it is unlikely that the $6 B t k b 5$ horizon (unit 6D) would, in part, be preserved on both sides of the fault (fig. 14). The most vulnerable exposure is the free face of the footwall, where the $6 B t k b 5$ horizon is preserved. These units were subsequently faulted (fig. 15D). The fault formed as a normal fault, with the west side down, with an offset of approximately 26 centimeters. A component of strike-slip motion during the first two events cannot be ruled out.

Three soil horizons can be distinguished within the soil formed on unit 5D. These horizons are separated primarily on the basis of color, texture, structure, and concentration of carbonate. The zone of clay accumulation overlies the zone of carbonate accumulation, as expected (table 7). This distribution indicates a period of subaereal exposure or very shallow burial.

Colluvium was deposited downslope, forming unit 4D (fig. 15D). This colluvial wedge pinches out about $4 \mathrm{~m}$ downslope to the west. Unit $4 \mathrm{D}$ is derived from the alluvium upslope (unit 5D). Unit 4D contains a larger fraction of material greater than $2 \mathrm{~mm}$ in size than unit 5D, indicating that coarse material was concentrated as fine material was washed away during erosion of the inferred parent material (unit 5D) (table 7). Alternatively, the coarseness could indicate that the colluvium was, in part, derived from coarser parent material than unit 5D, that the colluvium was not transported as far, or both. Unit 4D also has less secondary carbonate than unit 5D (table 7), suggesting that unit $4 \mathrm{D}$ is younger in age.

Although unit 5D in trench 14D resembles unit 2 in trench 14 , these units are not correlative. The soil developed in the unit $3 \mathrm{D}$, which overlies unit $5 \mathrm{D}$, is probably considerably older than unit 2 which is dated at $38 \pm 10$ and $55 \pm 20 \mathrm{ka}$ (table 4).

\section{Event Three}

Prior to a third faulting event, unit 3D was deposited over units $4 \mathrm{D}$ and $5 \mathrm{D}$ and across the exposed fault (fig. 15E). In places, unit 5D has a preserved, thin platy structure at the top of the unit, which formed after the deposition of unit 4D (table 7). Where carbonate is lacking, a platy structure is characteristic of an $A$ horizon. The $A$ horizon would be rapidly removed from the footwall by erosion resulting from a normal faulting event. Therefore, it is improbable that faulting occurred after event two, after the deposition of unit $4 \mathrm{D}$, and prior to the deposition of unit 3D.

Soil horizons subsequently formed on unit 3D (fig. 15E). Within the exposed sediments in trench $14 \mathrm{D}$, unit 3D records a third repetition of the clay maximum over the carbonate maximum sequence (table 7). A possible explanation for this repeated sequence could be a climatic trend toward less effective precipitation, where less water is available for the transport of clay in suspension and carbonate in solution. Although this climatic record may be present in unit 3D, continual deposition of clay and carbonate has made the 
determination of the effect of climate on the clay and carbonate sequence difficult.

The third faulting event is clearly recorded in the offset of the opaline silica- and carbonate-cemented soil horizon (3Bkqb2) (fig. 14) developed on unit 3D and in the offset of the surface composed of units 4D and 5D (fig. 15F). Almost vertical carbonate stringers line the fracture within unit 3D (fig. 14). A vertical offset of $12 \mathrm{~cm}$ down to the west was measured (fig. 14).

Units $1 \mathrm{D}$ and $2 \mathrm{D}$ were deposited across the fault. There is no evidence that these units were fractured during event three; the fault zone has been actively disrupted by animals and roots. No chunks of $A v$ horizon material were present in the fault zone to suggest that unit 1D was offset by the faulting in event 3 .

A deposit that could correlate with unit 3D is not present in trench 14 . It could be a slope-sequence phenomenon, where the soils adjacent to the bedrock scarp, which is exposed in trench 14 , are at a slope angle high enough to prevent stable-surface kinds of pedogenic processes to occur. Such a phenomenon may not have occurred in the area of trench 14D. This may not be the case in the location of trench 14D. There is no simple explanation for the formation and preservation of unit 3D in the area of trench 14D.

Based on the estimated ages of units $2 \mathrm{D}$ and $3 \mathrm{D}$, faulting occurred between 145,000 and 10,000 years ago.

\section{Summary of Faulting Events}

The depositional history, soil formation, and faulting events exposed in trench 14D can be summarized as follows:

1. Slope-wash alluvium was deposited between $270,000 \pm 90,000$ and $480,000 \pm 90,000$ years ago (unit 7D) (fig. 15A). A soil with a well developed $K$ horizon developed on unit 7D. Soil horizons above the $K$ horizon were stripped, and the first faulting event occurred with movement down to the west sometime between about 145,000 and 270,000 \pm 90,000 years ago (fig. 15B). The amount of offset, measured at the top of unit 7D, was about $13 \mathrm{~cm}$. The cumulative offset is $51 \mathrm{~cm}$. Slope-wash alluvium (unit 6D) was deposited over unit 7D, and the colluvium derived from the first faulting event. A soil developed on the deposit that has a $B t k$ horizon above the $K$ horizon (fig. 15B).

2. Alluvium was deposited in a channel adjacent to and across the fault zone (unit 5D) (fig. 15C).
The $B t k$ horizon (unit 6D) was eroded in places down to the resistant $K$ horizon (unit 7D). The second faulting event occurred with movement down to the west also sometime between about 150,000 and $270,000 \pm 90,000$ years ago. The amount of offset, measured at the top of unit $6 \mathrm{D}$, was about $26 \mathrm{~cm}$ (fig. 14). The cumulative offset is $38 \mathrm{~cm}$. Colluvium (unit 4D) was deposited adjacent to the fault scarp (fig. 15D).

3. A layer of slope-wash alluvium (unit 2D) was deposited on the older colluvial units and across the fault. A soil developed across the fault on the slope-wash alluvium. A third faulting event occurred with a vertical component of movement down to the west. The about of offset, measured at the base of unit 2D, was $12 \mathrm{~cm}$.

4. The slope-wash alluvium (unit 3D) was buried by a unit composed of slope-wash alluvium and eolian silt and sand (units 1D and 2D). There has been considerable bioturbation in the fault zone, and there is no preserved evidence for offset of either unit.

\section{SUMMARY}

Trench 14 was excavated across the Bow Ridge Fault on the west side of Exile Hill to study the nature and frequency of Quaternary movement on the fault. Quaternary depositional units between the ages of $480,000 \pm 90,000$ years and latest Pleistocene to early Holocene are in fault contact with brecciated volcanic tuff of Tertiary age. The main fault is characterized by vertical veins that intersect both the Quaternary deposits and the Tertiary bedrock. These veins contain primarily fine-grained sediments, secondary calcium carbonate and opaline silica, and a black ash. There is also a minor component of local rock fragments. The exposure provided very little information for the interpretation of Quaternary faulting on the Bow Ridge Fault. However, concern arose as to the origin of the secondary calcium carbonate and opaline silica in the vertical veins exposed in the fault zone. The veins physically resemble those found in spring deposits formed by ascending water. Physical, chemical, mineralogical, biologic, petrographic, and isotopic data collected indicate the calcium carbonate and opaline silica in the veins and slope-wash alluvium are characteristic of an environment with descending water-a pedogenic environment. 
Two general azimuth orientations on fractures are observed in trench 14 . About 85 percent of the bedrock fractures are oriented northwest, and the remainder of bedrock fractures and all of the fractures in the slope-wash alluvium are oriented northeast.

Trench 14D was excavated $50 \mathrm{~m}$ south of trench 14 to expose the Bow Ridge Fault in Quaternary deposits, and not at a bedrock-slope-wash alluvium contact. The depositional units exposed in trench 14 are present in trench 14D with the exception of a unit that contains a soil that is cemented with secondary opaline silica and clay (unit 2D). This unit is not present in trench 14. At least three tectonic events on the Bow Ridge Fault are recorded in the depositional units exposed in trench 14D. The deepest and oldest unit (unit 7D) can be correlated to the basal unit in trench 14 which is dated between $270,000 \pm 90,000$ and $480,000 \pm 90,000$ years. Unit 7D is offset vertically down to the west $51 \mathrm{~cm}$. The preserved soil developed on unit 7D, that is offset, was well developed at the time of faulting, therefore, the ages provide a maximum for the time of faulting. Two younger units above the basal unit are offset 26 and $12 \mathrm{~cm}$. The unit $3 \mathrm{D}$, that is characterized by the opaline silica cemented zone, can be correlated on the basis of its stratigraphic position and its physical and chemical properties with similar deposits in the Yucca Mountain region which are dated or inferred to vary in age from 145 to $190 \mathrm{ka}$. The timing of offset for the near-surface deposits must have occurred between about 270 and $150 \mathrm{ka}$. There is no evidence to date for Holocene displacement.

\section{REFERENCES CITED}

Bachman, G.O., and Machette, M.N., 1977, Calcic soils and calcretes in the southwestern United States: U.S. Geological Survey Open-File Report 77-794, 163 p. (NNA.911114.0031)

Benson, L.V., and McKinley, P.W., 1985, Chemical composition of ground water in the Yucca Mountain area, Nevada, 1971-84: U.S. Geological Survey Open-File Report 85-484, 10 p. (NNA.890522.0210)

Benson, L.V., and Klieforth, Harold, 1989, Stable isotopes in precipitation and ground water in the Yucca Mountain region, southern Nevada-Paleoclimatic implications, in Peterson, D.H., ed., Aspects of climate variability in the Pacific and western Americas: American Geophysical Union Geophysical Monograph 55, p. 41-59. (NNA.910617.0057)

Birkeland, P.W., 1984, Soils and geomorphology: New York, Oxford University Press, $372 \mathrm{p}$. (NNA.910128.0129)

Bullock, P., Fedoroff, N., Jongerius, A., Stoops, G., and Tursina, T., 1985, Handbook for soil thin section description: Wolverhampton, England, Waine Research, 152 p. (MOL.19940725.0006)

Crowe, B.M., and Car, W.J., 1980, Preliminary assessment of the risk of volcanism at a proposed nuclear waste repository in the southern Great Basin: U.S. Geological Survey Open-File Report 80-357, 15 p. (HQZ.870302.0219)

Gile, L.H., Hawley, J.W., and Grossman, R.B., 1981, Soils and geomorphology in the Basin and Range area of southern New Mexico - Guidebook to the Desert Project: New Mexico Bureau of Mines and Mineral Resources Memoir 39, 222 p. (NNA.921106.0020)

Gile, L.H., Peterson, F.F., and Grossman, R.B., 1966, Morphological and genetic sequences of carbonate accumulations in desert soils: Soil Science, v. 101, no. 5, p. 347-360. (HQS.880517.2684)

Goddard, E.N., Trask, P.D., De Ford, R.K., Rove, O.N., Singewald, J.T. Jr., and Overbeck, R.M., 1948, Rockcolor chart: Washington, D.C., National Research Council, $6 \mathrm{p}$. [Reprinted by Geological Society of America, 1975] (MOL.19940725.0003)

Hoover, D.L., Swadley, W.C., and Gordon, A.J., 1981, Correlation characteristics of surficial deposits with a description of surficial stratigraphy in the Nevada Test Site region: U.S. Geological Survey Open-File Report 81-512, 27 p. (NNA.870406.0033)

Jones, B.F., 1983, Occurrence of clay minerals in surficial deposits of southwestern Nevada: Strasbourg, France, Sciences Geolgiques Memoire 72, p. 81-92. (MOL.19940714.0105)

Jones, J.B., and Signit, E.R., 1971, The nature of opal, I. Nomenclature and constituent phases: Geological Society of Australia Journal, v. 18, p. 57-68. (NNA.921103.0010)

Marvin, R.F., Byers, F.M. Jr., Mehnert, H.H., Orkild, P.P., and Stern, T.W., 1970, Radiometric ages and stratigraphic sequence of volcanic and plutonic rocks, southern Nye and western Lincoln Counties, Nevada: Geological Society of America Bulletin, v. 81, no. 9, p. 2657-2676. (NNA.930118.0006)

McFadden, L.D., and Tinsley, J.C., 1985, Rate and depth of pedogenic-carbonate accumulation in soilsFormulation and testing of a compartment model, in Weide, D.L., ed., Soils and Quaternary geology of the southwestern United States: Geological Society of America Special Paper, 203, p. 23-41. (HQS.880517.3139)

Muhs, D.R., Whitney, J.W., Shroba, R.R., Taylor, E.M., and Bush, C.A., 1990, Uranium-series dating of secondary carbonates near Yucca Mountain, Nevada-Applications to tectonic, paleoclimatic, and paleohydrologic problems, in Proceedings of the International Topical Meeting, High-level radioactive waste management: Las Vegas, American Nuclear Society, Inc., v. 2 , p. 924-929. (NNA.900523.0227) 
Munsell Color Company, Inc., 1990, Munsell soil color charts: Baltimore, Md. (NNA.920207.0001)

Nettleton, W.D., and Peterson, F.F., 1983, Aridisols, in Wilding, L.P., Smeck, N.E., and Hall, G.F., eds., Pedogenesis and soil taxonomy-v. II, The soil orders: New York, Elsevier, p. 165-214. (MOL.19940714.0106)

Pettijohn, F.J., Potter, P.E., and Siever, Raymond, 1987, Sand and sandstone: New York, Springer-Verlag, p. 553. (MOL.19940805.0089)

Quade, Jay, and Cerling, T.E., 1990, Stable isotopic evidence for a pedogenic origin of carbonates in trench 14 near Yucca Mountain, Nevada: Science, v. 250, p. 1549-1552. (NNA.910326.0100)

Quade, Jay, Cerling, T.E., and Bowman, J.R., 1989, Systematic variations in the carbon and oxygen isotopic composition of pedogenic carbonate along elevation transects in the southern Great Basin, United States: Geological Society of America Bulletin, v. 101, p. 464-475. (NNA.910617.0011)

Rosholt, J.N., Bush, C.A., Carr, W.J., Hoover, D.L., Swadley, W.C., and Dooley, J.R. Jr., 1985, Uraniumtrend dating of Quaternary deposits in the Nevada Test Site area, Nevada and California: U.S. Geological Survey Open-File Report 85-540, 72 p. (NNA.931102.0006)

Rosholt, J.N., Colman, S.M., Stuiver, M., Damon, P.E., Naeser, C.W., Naeser, N.D., Szabo, B.J., Muhs, D.R., Liddicoat, J.C., Forman, S.L., Machette, M.N., and Pierce, K.L., 1991, Dating methods applicable to the Quaternary, in Morrison, R.B. ed., Quaternary nonglacial geology; Conterminous U.S.: Boulder, Colorado, Geological Society of America, The Geology of North America, v, K-2, p. 55-60.

(NNA.921125.0015)

Sawyer, D.A., Fleck, R.J., Lanphere, M.A., Warren, R.G., and Broxton, D.E., 1990, Episodic volcanism in the southwest Nevada volcanic field: $\mathrm{New}{ }^{40} \mathrm{Ar}{ }^{39} \mathrm{Ar}$ geochronologic results: EOS Transactions, American Geophysical Union, v. 71, no. 43, p. 1296. (NNA.920319.0008)

Scott, R.B., and Bonk, Jerry, 1984, Preliminary geologic map of Yucca Mountain, Nye County, Nevada, with geologic sections: U.S. Geological Survey Open-File Report 84-494, 3 sheets, scale 1:12,000. (HQS.880517.1443)

Soil Survey Staff, 1975, Soil taxonomy, A basic system of soil classification for making and interpreting soil surveys: U.S. Soil Conservation Service, U.S. Department of Agriculture Handbook 436, 754 p. (MOL.19940725.0007)

Stuckless, J.S., Peterman, Z.E., Forester, R.L., Whelan, J.F., Vaniman, D.T., Marshall, B.D., and Taylor, E.M., 1992, Characterization of fault-filling deposits in the vicinity of Yucca Mountain, Nevada: Waste Manage- ment 92, Tucson, 1992, Proceedings, p. 929-935. (NNA.921019.0187)

Stuckless, J.S., Peterman, Z.E., and Muhs, D.R., 1991, U and $\mathrm{Sr}$ isotopes in ground water and calcite, Yucca Mountain, Nevada: Evidence against upwelling water: Science, v. 254, p. 551-554. (NNA.920106.0001)

Summerfield, M.A., 1982, Distribution, nature and probable genesis of silcrete in arid and semi-arid southern Africa, in Yaalon, D.H., ed., Aridic soils and geomorphic processes: Catena Supplement 1, p. 37-65. [Jerusalem], Proceedings of the International Conference of the International Society of Soil Science. (MOL.19940714.0107)

1983, Silcrete as a paleoclimatic indicator-Evidence from southern Africa: Palaeogeography, Palaeoclimatology, Palaeoecology, v. 41, no. 1-2, p. 65-79. (MOL.19940714.0108)

Swadley, W.C., Hoover, D.L., and Rosholt, J.N., 1984, Preliminary report on late Cenozoic faulting and stratigraphy in the vicinity of Yucca Mountain, Nye County, Nevada: U.S. Geological Survey Open-File Report 84-788, 42 p. (NNA.870519.0104)

Taylor, E.M., 1986, Impact of time and climate on Quaternary soils in the Yucca Mountain area of the Nevada Test Site: Boulder, University of Colorado, Master's thesis, 217 p. (NNA.920512.0016)

Turrin, B.D., Champion, Duane, and Fleck, R.J., 1991, ${ }^{40} \mathrm{Ar}{ }^{39} \mathrm{Ar}$ age of the Lathrop Wells volcanic center, Yucca Mountain, Nevada: Science, v. 253, p. 654-667. (NNA.911112.0006)

Vaniman, D.T., Bish, D.L., and Chipera, S., 1988, A preliminary comparison of mineral deposits in faults near Yucca Mountain, Nevada, with possible analogs: Los Alamos, New Mexico, Los Alamos National Laboratory Report LA-11289-MS, 54 p. (NNA.870521.0027)

Wells, S.G., McFadden, L.D., Renault, C.E., and Crowe, B.M., 1990, Geomorphic assessment of late Quaternary volcanism in the Yucca Mountain area, southern Nevada: Implications for the proposed high-level radioactive waste repository: Geology, v. 18, p. 549-553. (NNA.901130.0030)

Winograd, I.J., and Doty, G.C., 1980, Paleohydrology of the southern Great Basin, with special reference to water table fluctuations beneath the Nevada Test Site during the late(?) Pleistocene: U.S. Geological Survey OpenFile Report 80-569, 91 p. (NNA.870518.0073)

Yount, J.C., Shroba, R.R., McMasters, C.R., Huckins, H.E., and Rodriguez, E.A., 1987, Trench logs from a strand of the Rock Valley fault system, Nevada Test Site, Nye County, Nevada: U.S. Geological Survey Miscellaneous Field Studies Map MF-1824, no scale listed. (NNA.930831.0107) 


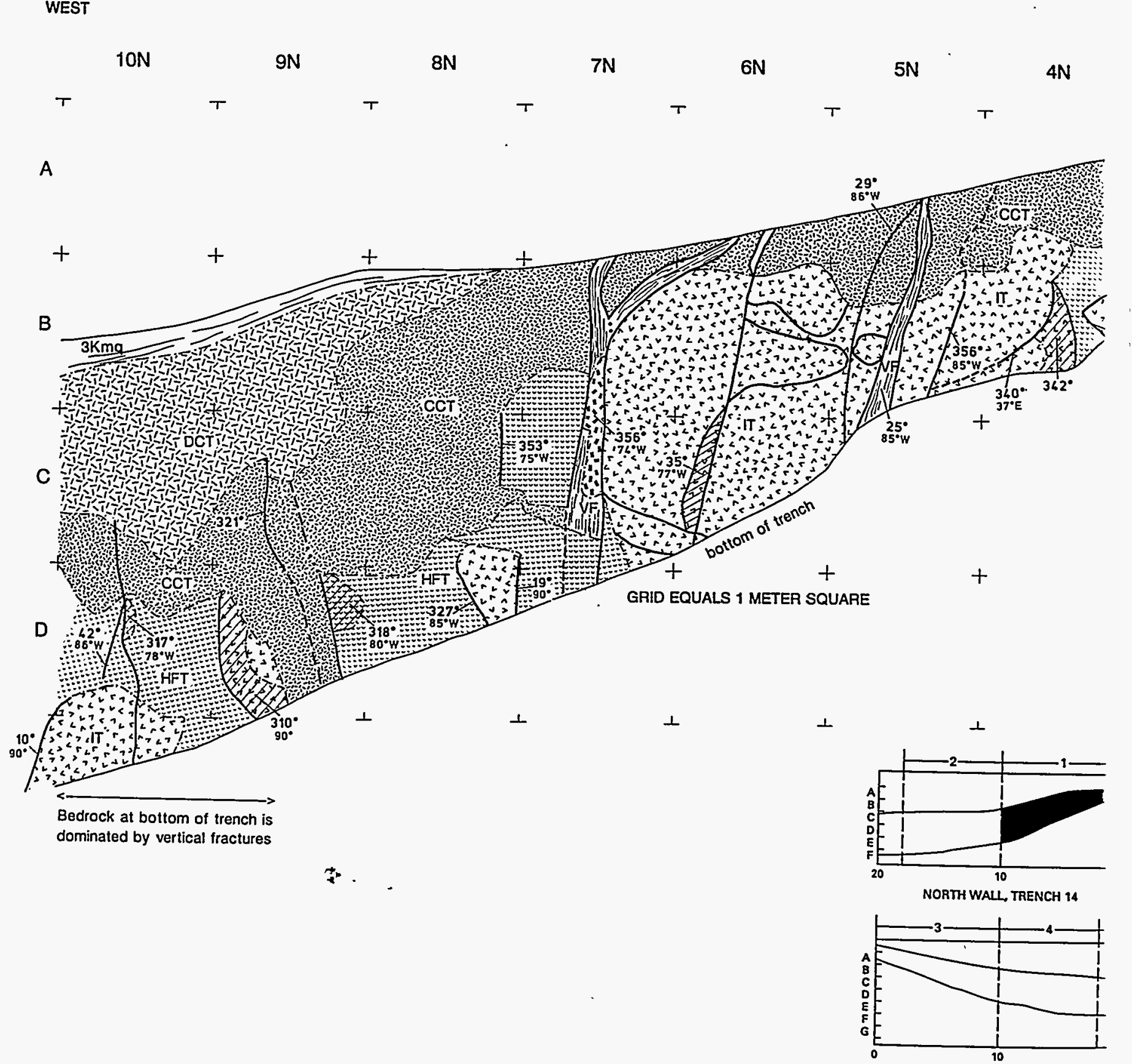

\section{A. GEOLOGIC SECTION SHOWING THE BEDROCK EXPOSED ON THE NORTH ON THE BOW RIDGE FAULT AT EXILE HILL, NYE COUNT}

EAST

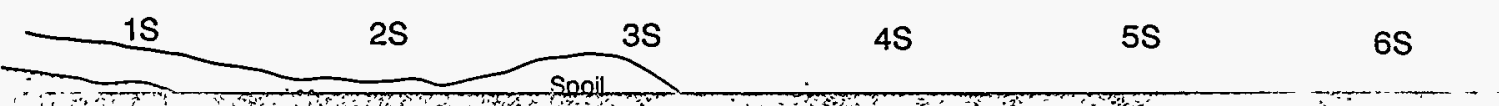




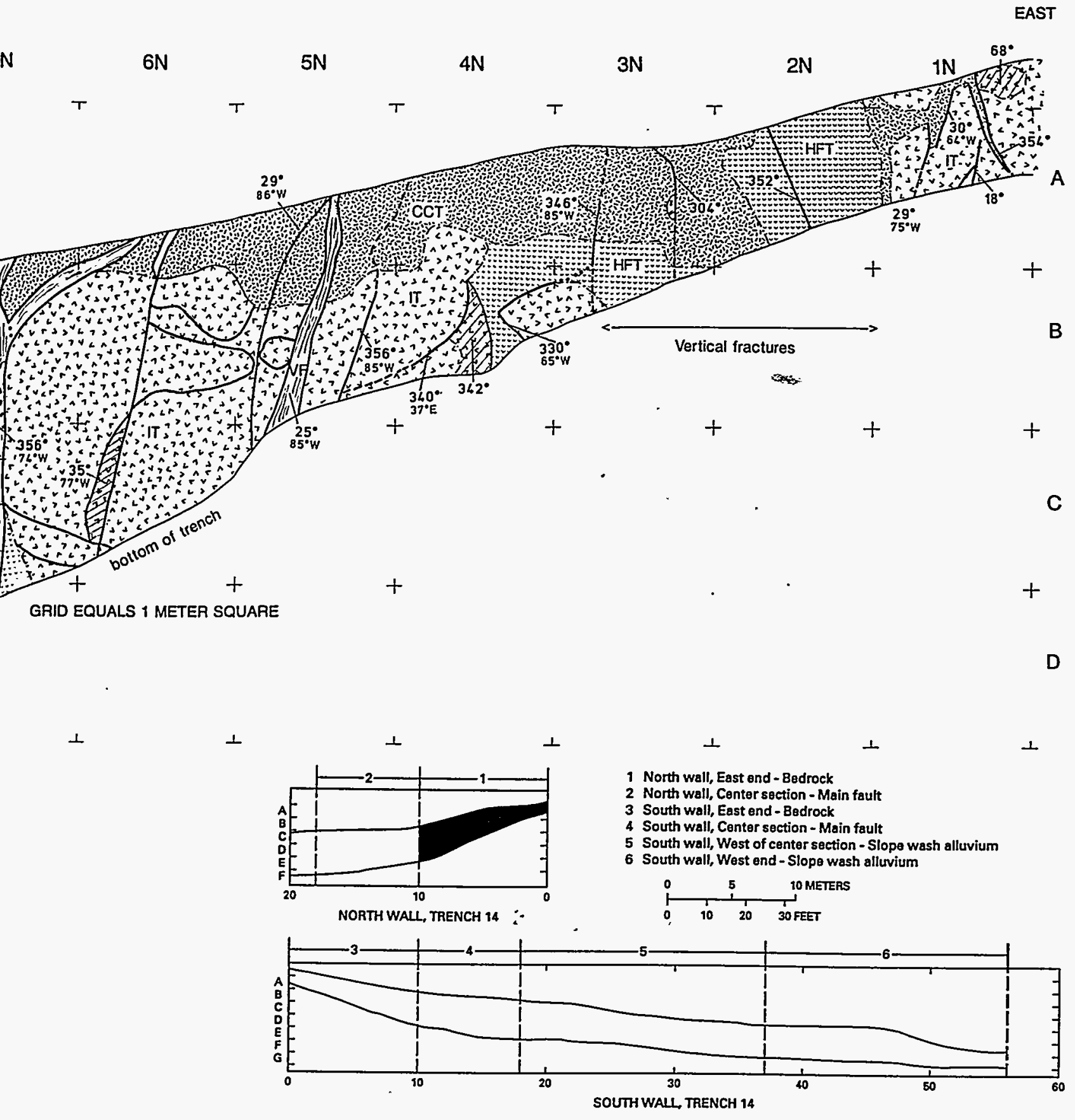

\section{E BEDROCK EXPOSED ON THE NORTH WALL, EAST END OF TRENCH 14 DGE FAULT AT EXILE HILL, NYE COUNTY, NEVADA}


EAST

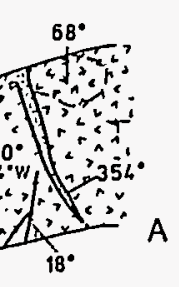

$+$

B

$+$

C

$+$

D

$\perp$
WEST

$r$

$18 N$

$T$
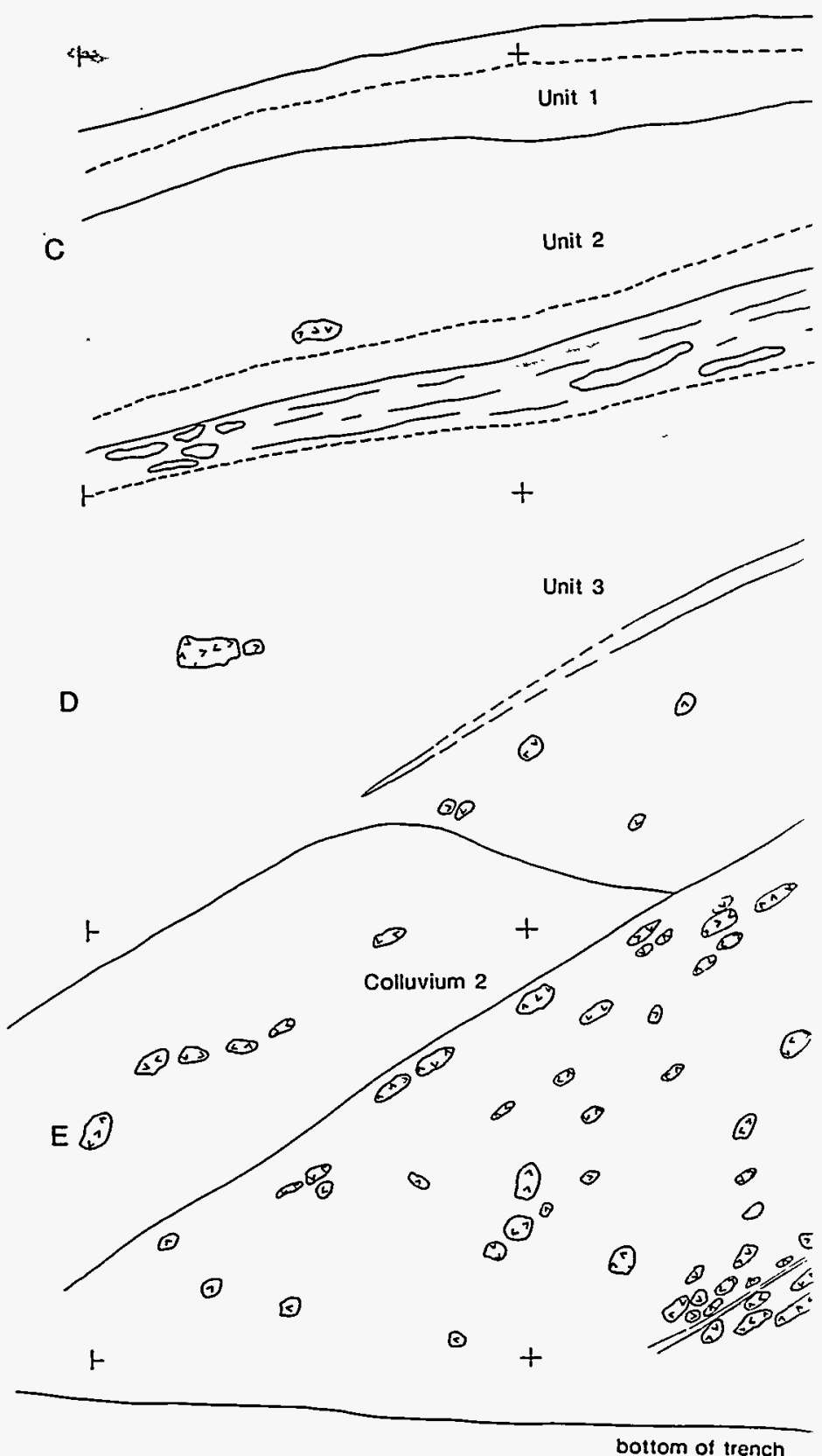

F

GRID EQUALS 1 METER SQUARE 
EAST
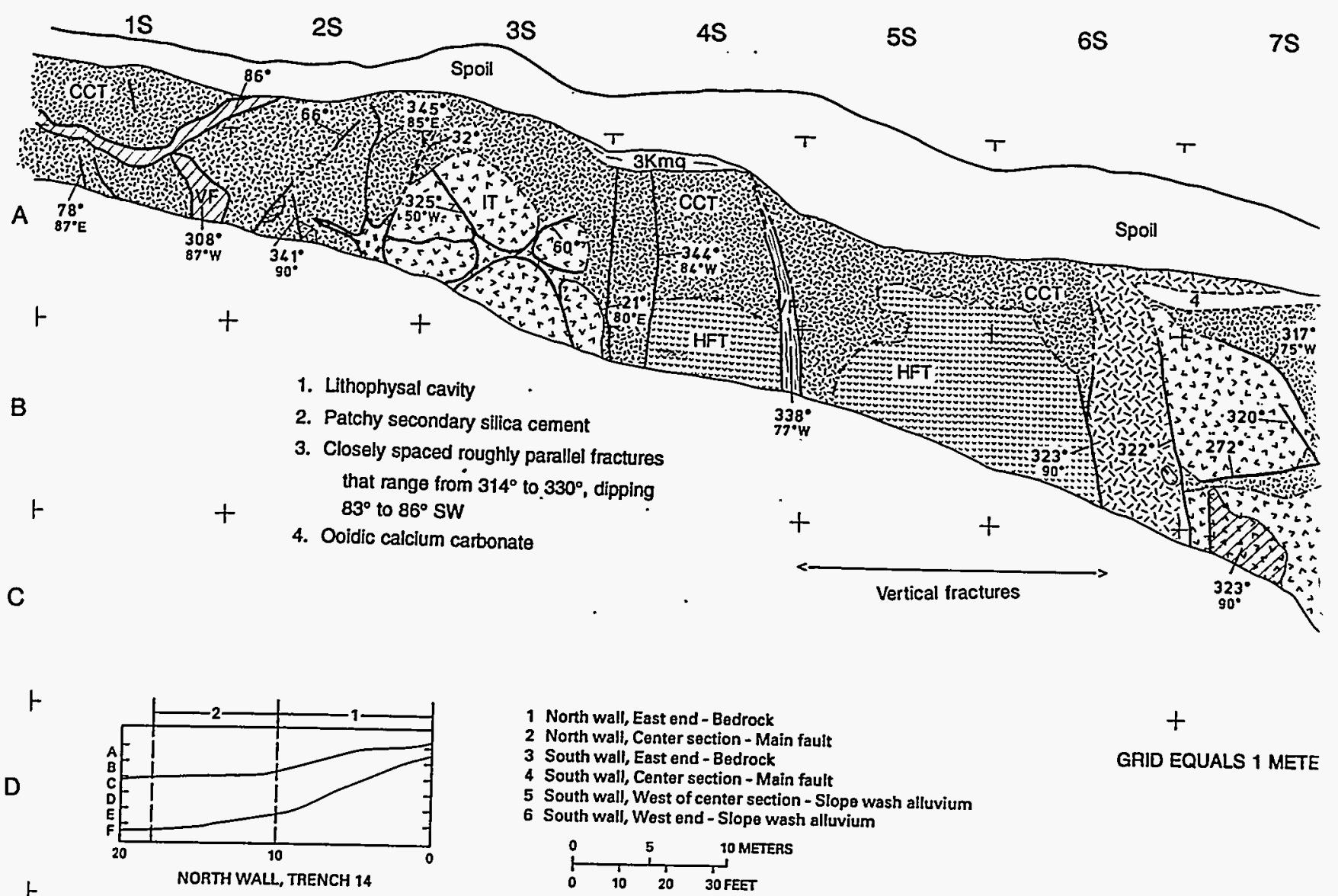

$+$

$\vdash$

NORTH WALL, TRENCH 14

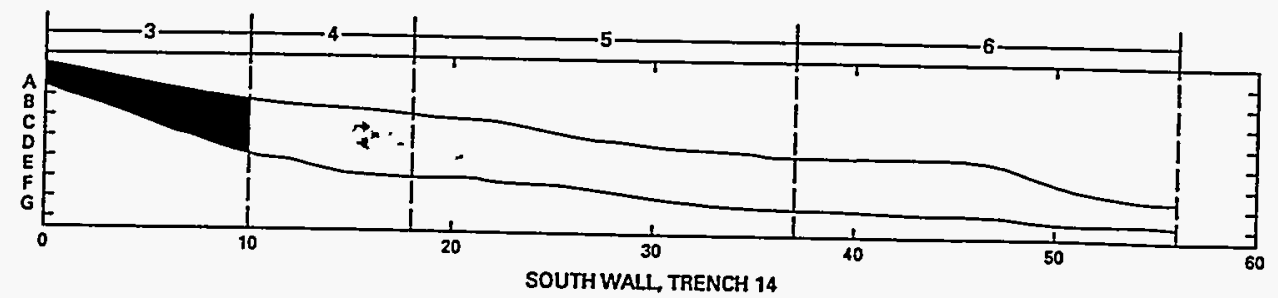

GAID EQUALS 1 METE

\section{GEOLOGIC SECTION SHOWING THE BEDROCK EXPOSED ON TH ON THE BOW RIDGE FAULT AT EXILE HILL, $N$}

\section{DESCRIPTION OF MAP UNITS}


$5 S$

$6 S$

75

85

$9 S$

105

WEST

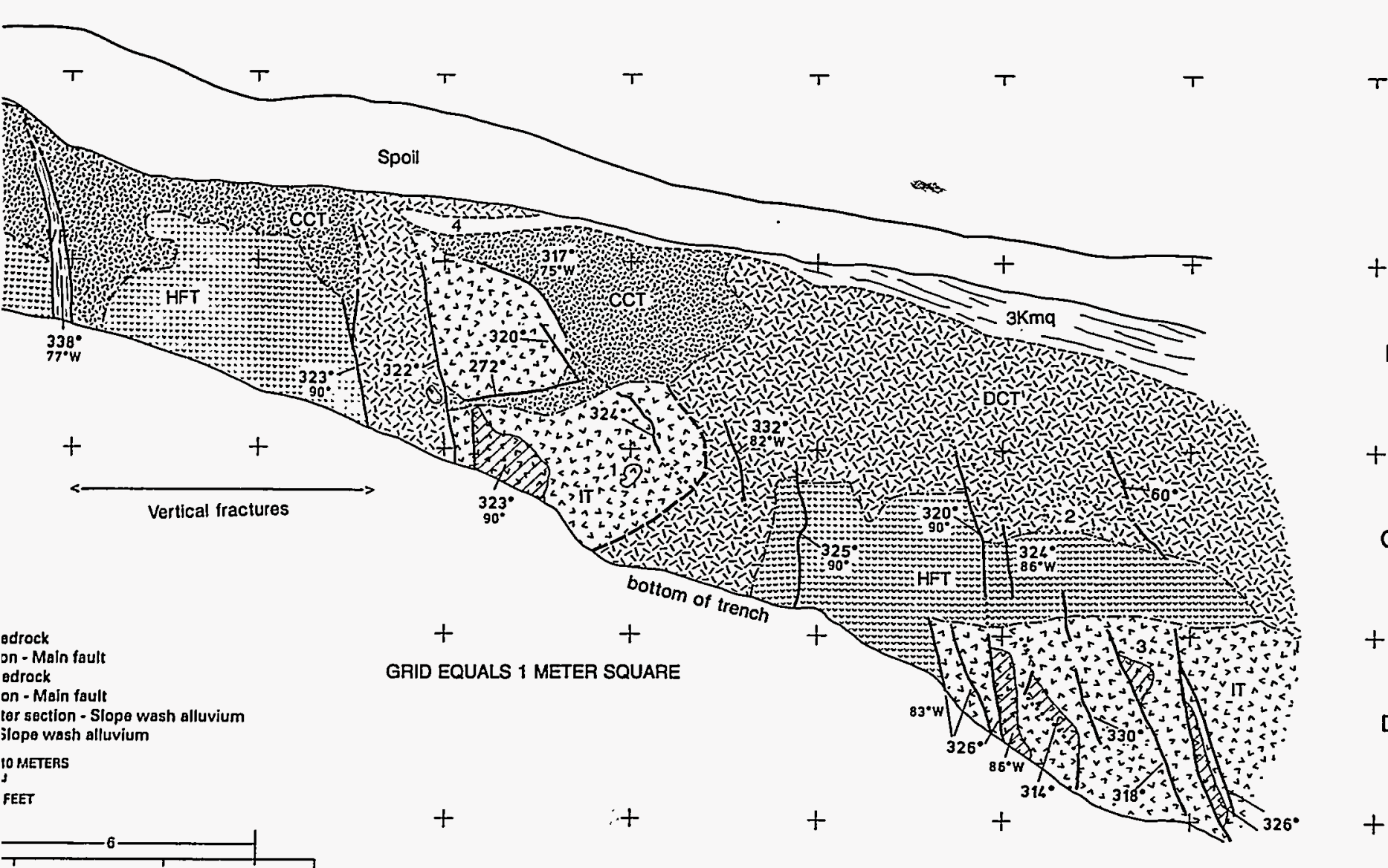

Bedrock at bottom of trench is dominated by vertical fractures

A

$+$

B

$+$

C

$+$

D

$+$

E 


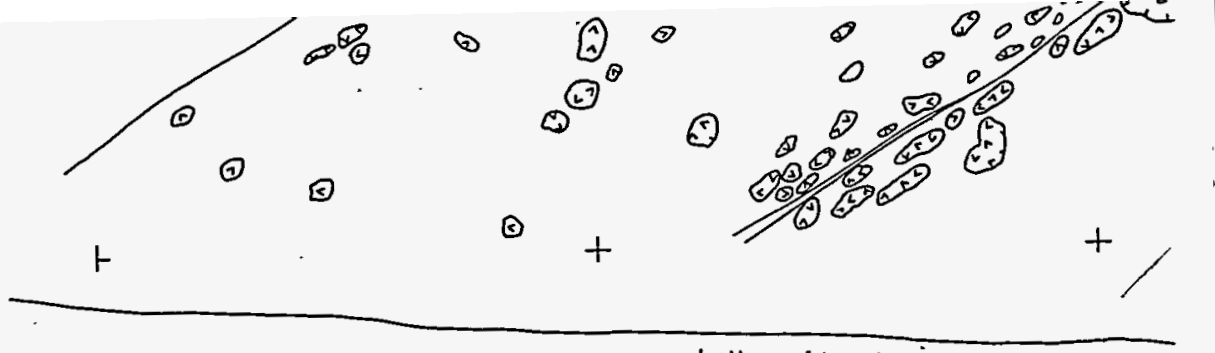

bottom of trench

$F$

GRID EQUALS 1 METER SQUARE

WEST

A

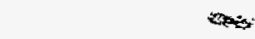

$+$

B. GEOLOGIC

B

$+$

C

$+$

D

EAST

$\vec{*}$.

$+$

E

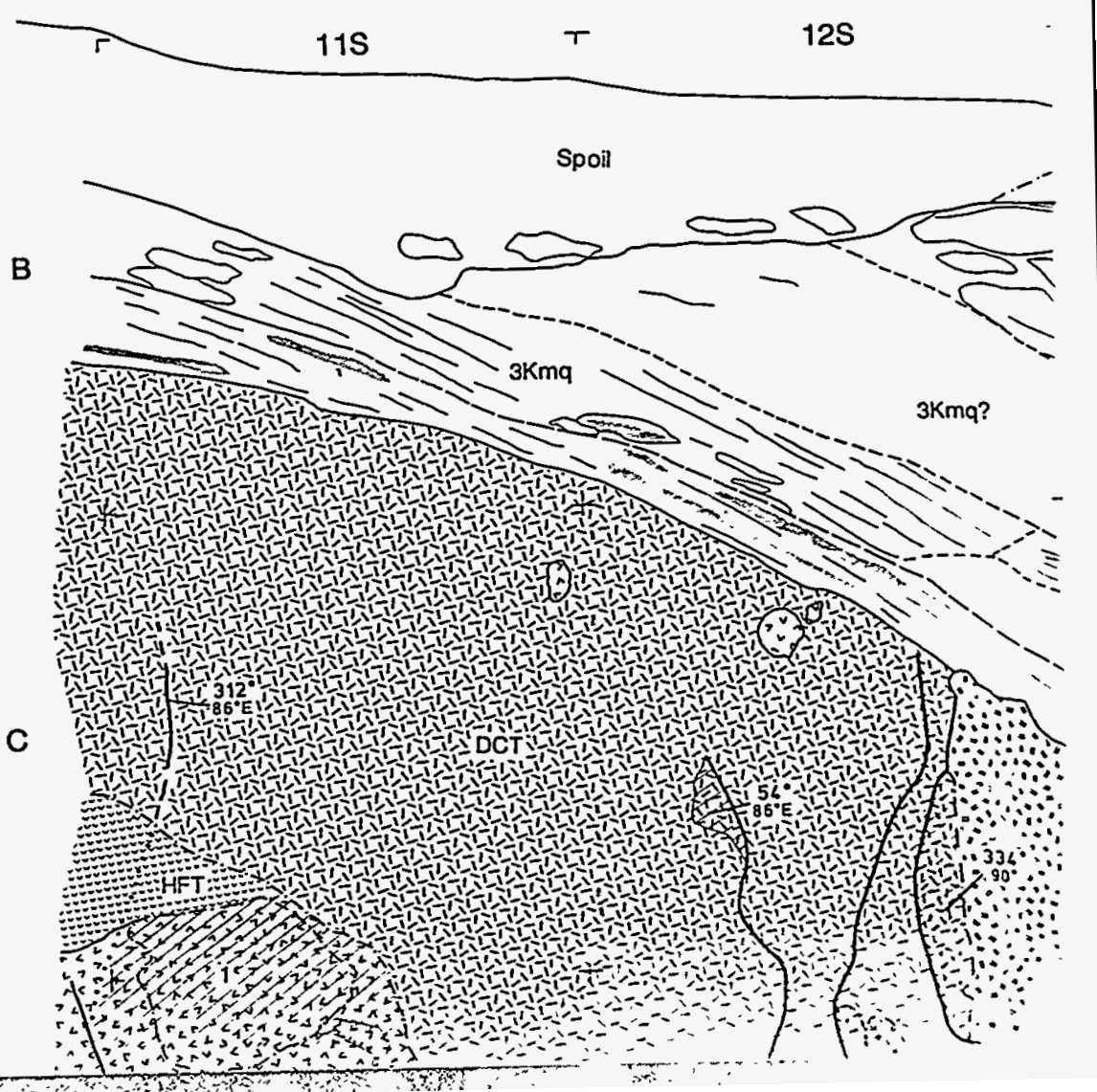




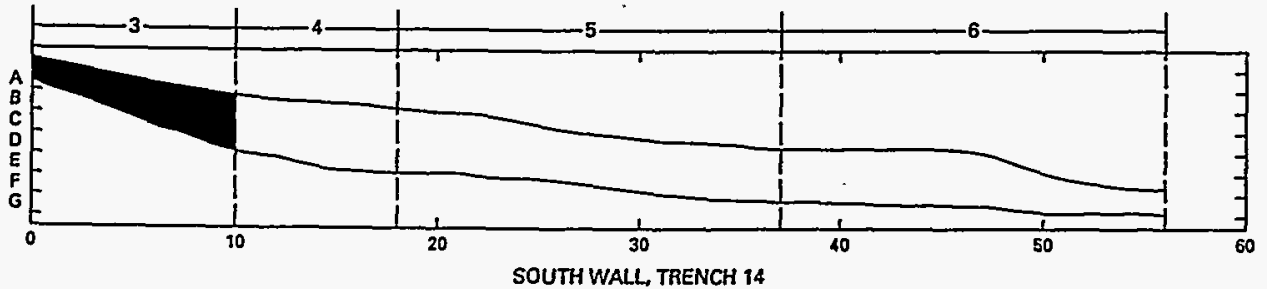

\section{GEOLOGIC SECTION SHOWING THE BEDROCK EXPOSED ON THE SC ON THE BOW RIDGE FAULT AT EXILE HILL, NYE Ci}

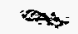 \\ DESCRIPTION OF MAP UNITS}

\section{TERTIARY VOLCANIC ROCKS}

$\because$ Nivi. $\therefore$ Highly fractured nonwelded tuff (late Miocene)-Grayish-orange-pink, nonwelded ash-flow tuff, stratigraphically located between Rainier Mesa Member of Timber Mountain Tuff and Tiva Canyon Member of Paintbrush Tuff. Unit is characterized by white, pinkish-gray, and paleyellowish-brown vitric pumice, about 15 percent phenocrysts which are chiefly quartz and feldspar with sparse bronze biotite, about 5 percent lithic fragments of Paintbrush Tuff and Tuff of Calico Hills, and granules of brown glass. Unit is highly fractured and fractures are infiltrated with secondary carbonate and fine-grained sand and silt. Unit is exposed only on the center section of north wall

Slightly fractured intact Tiva Canyon Member of the Paintbrush Tuff (middle Miocene)-Pale-red, devitrified, moderately to densely welded ash-flow tuff, stratigraphically from upper lithophysal zone of the Tiva Canyon Member. Unit is charácterized by sparse, very light gray to light gray pumice which is flattened about $4: 1$ to $6: 1$, about 10-12 percent phenocrysts which are chiefly sanidine and plagioclase with rare biotite, very rare lithic fragments, and small Mn-oxide dendrites throughout groundmass. Abundant lithophysal cavities, as large as $10 \mathrm{~cm}$ across, are lined with vapor phase minerals, botryoidal chalcedony, and drusy quartz. Unit is cut by cooling joints, some of which seem to have been reactivated during faulting and brecciation.

Highly fractured Tiva Canyon Member of the Paintbrush Tuff (middle Miocene)-Stratigraphically from the upper lithophysal zone of the Tiva Canyon Member. Differs from the intact Tiva Canyon Member (IT) only because it is highly fractured, but does not seem to be penetratively sheared. Fracture spacing is about $1-10 \mathrm{~cm}$ and most fractures are vertical and divide tuff into long, angular fragments or blocks. Lithophysae and pumice are not offset. Unit is characterized by containing drusy quartz which commonly lines lithophysal cavities, botryoidal quartz which locally coats fractures, and small amounts of secondary microcrystalline carbonate and opaline silica in fractures. Grades laterally into intact Tiva Canyon Member (IT), carbonate-cemented and fractured Tiva Canyon Member (CCB), and densely carbonate-cemented and fractured Tiva Canyon Member (DCB). Abundance of secondary carbonate decreases with depth in bedrock and in adjacent colluvium and slope-wash alluvium.

Carbonate-cemented and fractured Tiva Canyon Member of the Paintbrush Tuff (middle Miocene-modern)-Similar to the highly fractured Tiva Canyon Member (HFT) except unit is cut by fractures containing infiltrated sand and silt, with secondary carbonate and opaline silica. Secondary carbonate is white and decreases in abundance with

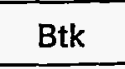

Btk horizon silty sand (sc from 15 to are angular Horizon is . near its ba: thin coatin boundary is $60 \mathrm{~cm}$.

Unit 2 Unit 2 (late Plel: compact, silty s: pebble-cobble subrounded. Ne cemented by se into the fine-gre there are two di

2Bti horiz compact, : that conta within gra cm across Basal bous to $30 \mathrm{~cm}$.

$2 \mathrm{~B} \div \mathrm{K} \quad 2 \mathrm{~B}+\mathrm{K}$ hor slightly co: texture: $s i$ cobble gre are as lar cemented have bee horizon, boundary $15 \mathrm{~cm}$.

Unit 三 Unit 3 (middle P. sorted sand to Consistence i: secondary car cemented. $\mathrm{Ca}$ there are five 3Kmq1 loamy sa clasts as character (stage 4) tiscrete 


\section{ED ON THE SOUTH WALL, EAST END OF TRENCH 14 E HILL, NYE COUNTY, NEVADA}

Btk horizon is a pale brown to dark brown, moderately sorted, silty sand (soil texture: loamy sand to sandy loam) that contains from 15 to 30 percent pebble-cobble gravel. Clasts within gravel are angular to subrounded and are as large as $20 \mathrm{~cm}$ across. Horizon is generally nonbedded but contains a few stone lines near its base. Consistence is soft. Secondary carbonate forms thin coatings on the underside of pebbles (stage 1). Basal boundary is abrupt and wavy, and thickness ranges from 10 to $60 \mathrm{~cm}$.

Unit 2 (late Pleistocene)-Light yellowish brown to yellowish brown, compact, silty sand, contains from 5 to 20 percent angular to subangular pebble-cobble gravel. Sand is moderately sorted, subangular to subrounded. Near base of unit 2 , indurated plates from unit. 3 , which are cemented by secondary carbonate and opaline silica, have been reworked into the fine-grained matrix. Unit 2 pinches out downslope. Within unit 2 there are two discrete soil horizons.

2Bti horizon is a yellowish brown to dark yellowish brown, compact, moderately sorted, silty sand (soil texture: sandy loam) that contains from 5 to 10 percent pebble-cobble gravel. Clasts within gravel are angular to subangular and are as large as 15 $\mathrm{cm}$ across. Horizon has a well-developed soil prismatic structure. Basal boundary is clear and wavy, and thickness ranges from 0 to $30 \mathrm{~cm}$.

$2 \mathrm{~B}+\mathrm{K}$ horizon is light yellowish brown to pale brown, and white, slightly compact and indurated, moderately sorted, sandy silt (soil texture: sandy loam) that contains from 5 to 20 percent pebblecobble gravel. Clasts within gravel are angular to subangular and are as large as $15 \mathrm{~cm}$ across. Horizon contains plates that are cemented by carbonate (stage IV) and opaline silica (stage 4) that have been moved up from or downslope from the $3 \mathrm{Kmql}$ horizon, which is immediately below the $2 \mathrm{~B}+\mathrm{K}$ horizon. Basal boundary is abrupt and smooth, and thickness ranges from 0 to $15 \mathrm{~cm}$.

Unit 3 (middle Pleistocene)-White to light gray, moderately well- to wellsorted sand to silty sand, pebble-cobble gravel, and contains rare boulders. Consistence is from soft to extremely hard where unit is indurated by secondary carbonate and opaline silica. Sandy matrix is weakly to well cemented. Carbonate along fracture surfaces is common. Within unit 3 , there are five discrete soil horizons. 


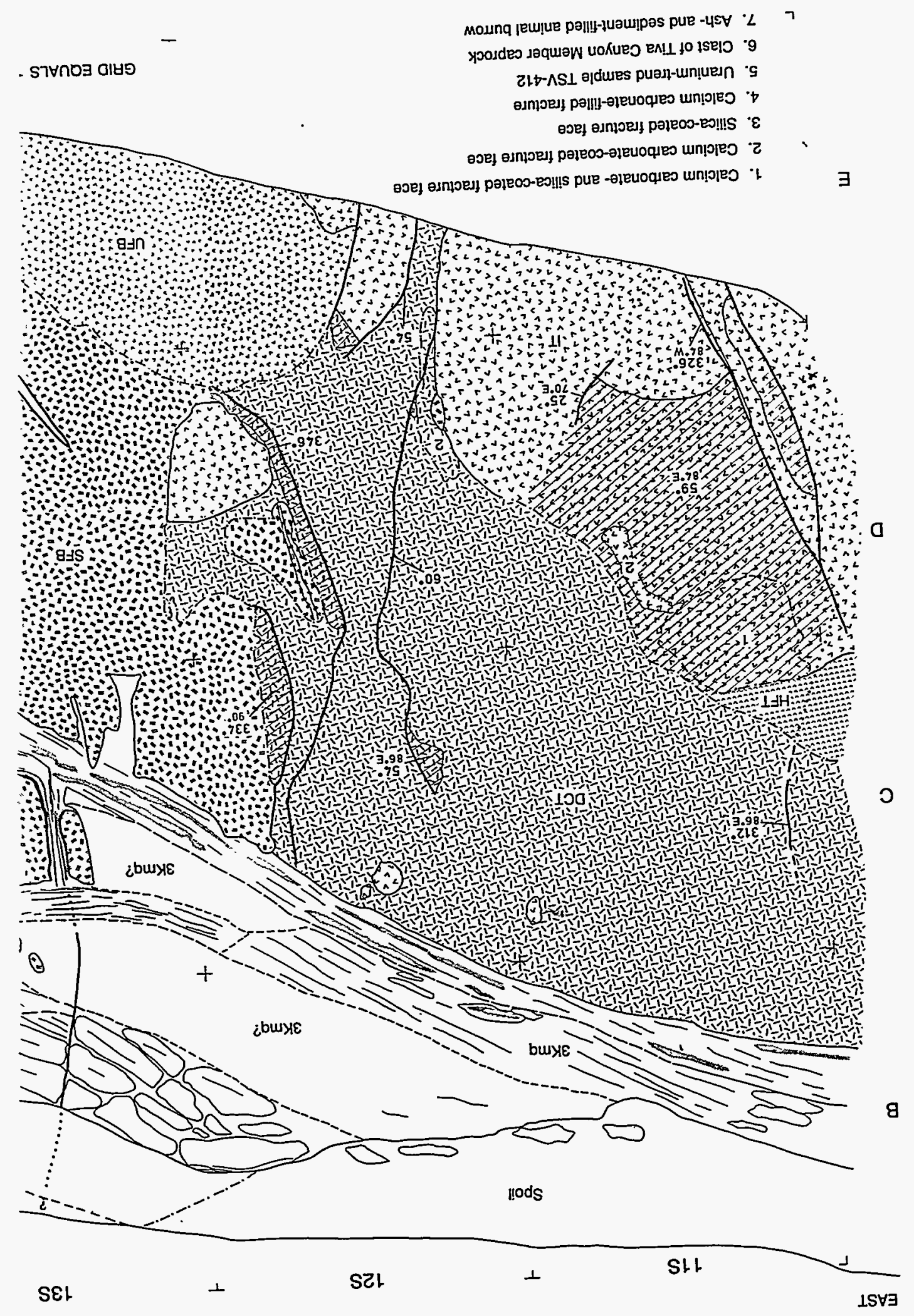




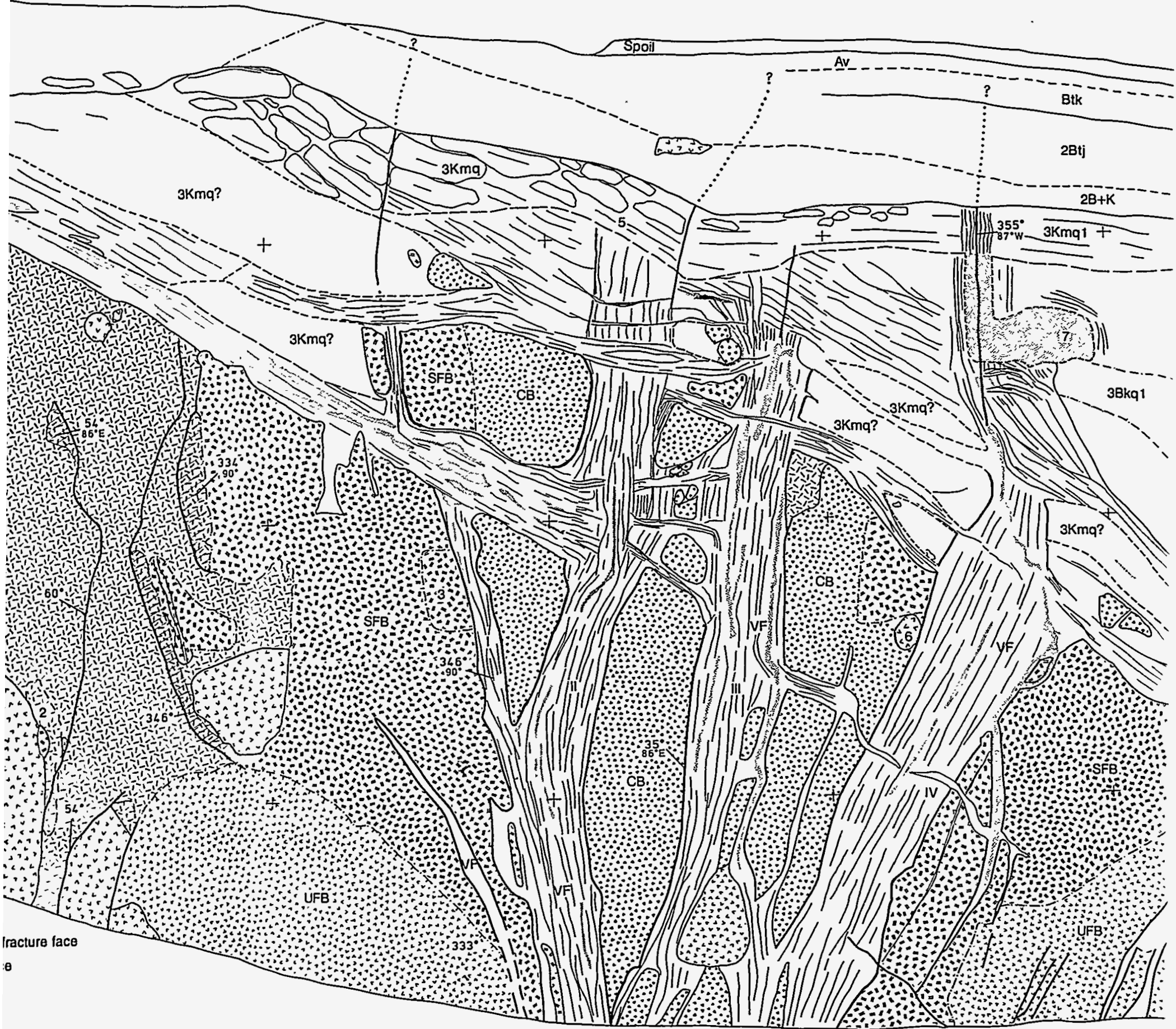

GRID EQUALS I METER SQUARE

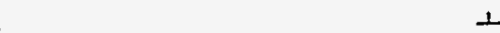


carbonate and opaline silica in fractures. Grades laterally into intact Tiva Canyon Member (IT), carbonate-cemented and fractured Tiva Canyon Member (ССВ), and densely carbonate-cemented and fractured Tiva Canyon Member (DCB). Abundance of secondary carbonate decreases with depth in bedrock and in adjacent colluvium and slope-wash alluvium.

Carbonate-cemented and fractured Tiva Canyon Member of the Paintbrush Tuff (middle Miocene-modern)-Similar to the highly fractured Tiva Canyon Member (HFT) except unit is cut by fractures containing infiltrated sand and silt, with secondary carbonate and opaline silica. Secondary carbonate is white and decreases in abundance with depth. Near the surface the fine-grained matrix is pinkish white and, in texture and structure, resembles a B soil horizon, containing opaline silica and clay, that has been engulfed by carbonate. Carbonate that fills fractures is powdery, carbonate that coats individual clasts is dense and smooth (stage II and III). Some of the opaline silica that fills interstices between rock fragments may have replaced earlier secondary carbonate. Fracture spacing is about $7-20 \mathrm{~cm}$, and ash-flow tuff is broken into angular to subrounded blocks. About 50 percent of fractiures are carbonate-filled, and locally blocks of bedrock are partly matrix supported. Unit grades into densely carbonate-cemented and fractured Tlua Canyon Member (DCT) and generally overlies and grades downward to highly fractured Tiva Canyon Member (HFT). -

Densely carbonate-cemented and fractured Tiva Canyon Member of the Paintbrush Tuff (middle Miocene-modern)-Similar to carbonatecemented Tiva Canyon Member (CCT) except that rock fragments are supported by an almost continuous matrix of secondary carbonate. Finegrained sediments infiltrate all of fractures. Unit is probably formed through weathering of the highly fractured Tiva Canyon Member (HFT).

\section{FAULT ZONE-BRECCIA AND VEINS}

Nonwelded tuff fault breccia (late Miocene) - Grayish-orange-pink, contains angular clasts $(0.5-2 \mathrm{~cm})$ of nonwelded tuff (NWT), and is within the main fault zone. Unit is formed from the nonwelded tuff (NWT). Unit contains fragments of silicified tuff and broken opaline silica vein material. Fragments are supported by a matrix of rock powder and secondary carbonate. Moderately indurated by secondary carbonate. Where in contact with veins, contact is gradational. Commonly in abrupt contact with opaline silica laminae. Stringers of carbonate are present. NWB is only exposed on the center section of the north wall.

Uncemented Tiva Canyon Member fault breccia (middle Miocene)-Light -gray to light-brownish-gray, consists of fragments of slightly fractured intact Tiva Canyon:Member (IT) with little matrix cement. Clasts range from silt-sized rock powder to angular fragments, $5-10 \mathrm{~cm}$ across. Where coarse-grained, unit is loose, and voids are lined with drusy and botryoidal quartz. Where fine-grained, unit is moderately indurated and silicified in places, especially where in contact with other units. Unit is probably a noncemented variant of the cemented cataclastic fault breccia (CB). Grades upward into the silica-cemented Tiva Canyon Member fault breccia (SFB) indicating that silicification is a near-surface process. Unit contains a few fractures filled with black ash.

Silica-cemented Tiva Canyon Member fault breccia (late-middle Miocene)-Angular to subrounded clasts of welded tuff, many of which are intact Tiva Canyon Member (IT), supported by a grayish-orange to pale-yellowish-brown opaline silica matrix. Clasts range in size from 0.1 to $12 \mathrm{~cm}$. Matrix is almost the same color as the secondary opaline silica that forms laminar plates in the slope-wash alluvium and dense stringers in the veins. Matrix cement in unit contains microcrystalline calcite as well as opaline silica. Most clasts smaller than $10 \mathrm{~cm}$ appear to be silicified. Unit is extremely hard, and fractures through rock fragments, some areas of softer carbonate-cemented breccia may be included. In places, botryoidal quartz is present as a coating on the silica-cemented fault breccia. Unit grades laterally to cemented cataclastic fault breccia (CB).

Cemented cataclastic fault breccia (late-middle Miocene)-Grayish-red and grayish red-purple. Toward edges of some of exposures, unit is light gray and grades to medium gray to medium dark gray where in contact with vein material. Unit is densely silicified and hard, opaline silica is not distinguishable in hand samples as a visible matrix. Commonly, silicification grades from well cemented where the cataclastic breccia is in contact with the veins, to less cemented between the veins toward the

3Kmq1

$3 \mathrm{Kmq} 2$

3Bkq 1

3Bkq2

Colluvium sorted sand t Consistence secondary ca cemented. C there are five 3Kmq1 loamy s clasts as characte (stage 4 discrete within $t$ to $40 \mathrm{cr}$ but obvi the uptr filling. I percent wavy, ar 3Kmq2

Horizon are con: 5 to $1 C$ plates Downsk infiltrate plates f evidence the infilt to soil $\mathrm{c}$ is from ( $3 \mathrm{Kq}$ ho texture: gravel $u$ by seco: opaline percent animal 1 and thic 3Bkq1 silty san percent Consiste gravel. III). Bet undersic Lenses silica str carbona massive adjacent Carboni main $f_{\bar{c}}$ stringer: below : thicknes 3Bkq2

(soil texı 15 perc as 16 consolid from th decreası Basal hi exposec Colluvium (ear bedrock anc the north $w$ slope-wash cemented $t$ bedded san from about 
Unit 3 Unit 3 (middle Pleistocene)-White to light gray, moderately well- to wellsorted sand to silty sand, pebble-cobble gravel, and contains rare boulders. Consistence is from soft to extremely hard where unit is indurated by secondary carbonate and opaline silica. Sandy matrix is weakly to well cemented. Carbonate along fracture surfaces is common. Within unit 3 , there are five discrete soil horizons.

3Kmq1 3Kmq1 horizon is white, well-sorted, silty sand (soil texture: loamy sand) that contains 20 percent pebble-cobble gravel with clasts as large as to $20 \mathrm{~cm}$ across. Horizon is indurated and characterized by carbonate, and opaline silica-cemented plates (stage 4). As much as 10 percent of horizon is composed of discrete opaline silica stringers that form sandwich-like zones within the platy carbonate. Discrete plates vary in length from 5 to $40 \mathrm{~cm}$ and in width from 3 to $10 \mathrm{~cm}$. Horizon is continuous, but obviously fractured, over the main fault zone and bedrock on the upthrown side of fault. In places, horizon merges with vein filling. Horizon contains lenses that consist of as much as 80 percent white ooidic carbonate. Basal boundary is abrupt and wavy, and thickness ranges from 0 to $50 \mathrm{~cm}$.

$3 \mathrm{Kmq} 23 \mathrm{Kmq} 2$ horizon is white to very pale brown, sand to silty sand. Horizon is very similar to $3 \mathrm{Kmq}$. Discrete plates in this hớtizon are considerably smaller than in $3 \mathrm{Kmq} 1$ and vary in length from 5 to $10 \mathrm{~cm}$ and in width from 3 to $5 \mathrm{~cm}$. Horizon thins and plates decrease in size, downslope away from main fault. Downslope, horizon also contains a greater percentage of infiltrated fine-grained sediments until, in some places, carbonate plates float in a matrix of fine-grained sediment. There is evidence of animal burrowing, but displacement of the plates by the infiltrated fine-grained sediments seems to be due primarily to soil creep. Basal boundary is abrupt and wavy, and thickness is from 0 to $50 \mathrm{~cm}$.

$3 \mathrm{Kq} \quad 3 \mathrm{Kq}$ horizon is white, moderately well-sorted, silty sand (soil texture: sandy loam) that contains from 5 to 40 percent pebble gravel with clasts as large as $4.5 \mathrm{~cm}$ across. Horizon is indurated by secondary carbonate (stage III) and contains thin stringers of opaline silica (stage 3 and 4 in places). In places as much as 50 percent of horizon is ooidic carbonate. Horizon contains filled animal burrows. Basal horizon boundary is abrupt and smooth, and thickness ranges from 0 to $50 \mathrm{~cm}$.

3Bkq 1 3Bkq1 horizon is white to brown, nonbedded and poorly sorted, silty sand (soil texture: loamy sand) that contains from 15 to 20 percent subangular to subrounded pebble-cobble gravel. Consistence is soft except för stringers of carbonate cemented gravel. Stringers consist of dense continuous carbonate (stage III). Between stringers, carbonate forms continuous coats on the underside of gravel clasts with some matrix bridging. (stage II). Lenses within stringers are entirely ooidic carbonate. Opaline silica stringers less than $4 \mathrm{~mm}$ thick are present, but rare, within carbonate stringers. Carbonate stringers within horizon are more massive and dip more steeply in the slope-wash alluvium that is adjacent to the main fault zone than they do downslope. Carbonate stringers are almost parallel to bedrock adjacent to main fault zone. Abundance and prominence of carbonate stringers and coarser gravel distinguish this horizon from horizon below (3Bkq2). Basal horizon boundary is abrupt and wavy, and thickness ranges from 50 to $175 \mathrm{~cm}$.

3Bkq2 3Bkq2 horizon is white to light gray to brown, sand to silty sand (soil texture: loamy sand to sandy loam) that contains from 10 to 15 percent angular to subrounded pebbles and cobbles as large as $16 \mathrm{~cm}$ across. Consistence is soft. Horizon is less consolidated than horizon 3Bkq1 and increases in thickness away from the main fault as carbonate stringers in above horizon decrease. Contains lenses that are entirely ooidic carbonate. Basal horizon boundary is not exposed, and thickness that is exposed ranges from 0 to $60 \mathrm{~cm}$.

Colluvium Colluvium (early to middle Pleistocene)-Immediately adjacent to the bedrock and stratigraphically below unit 3 , wedges of colluvium (two on the north wall and one on the south wall) can be distinguished from the slope-wash alluvium. Colluvium is white to light gray, soft to hard where 


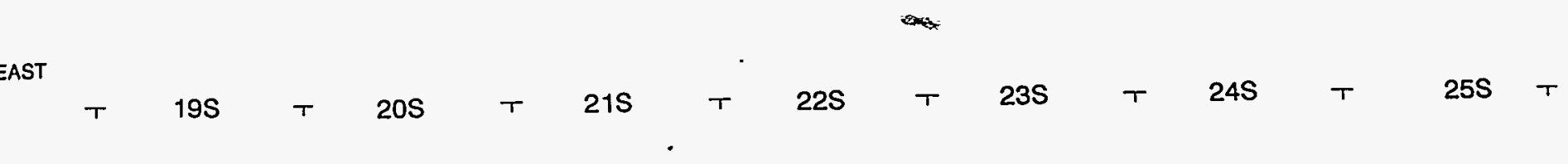

B

C

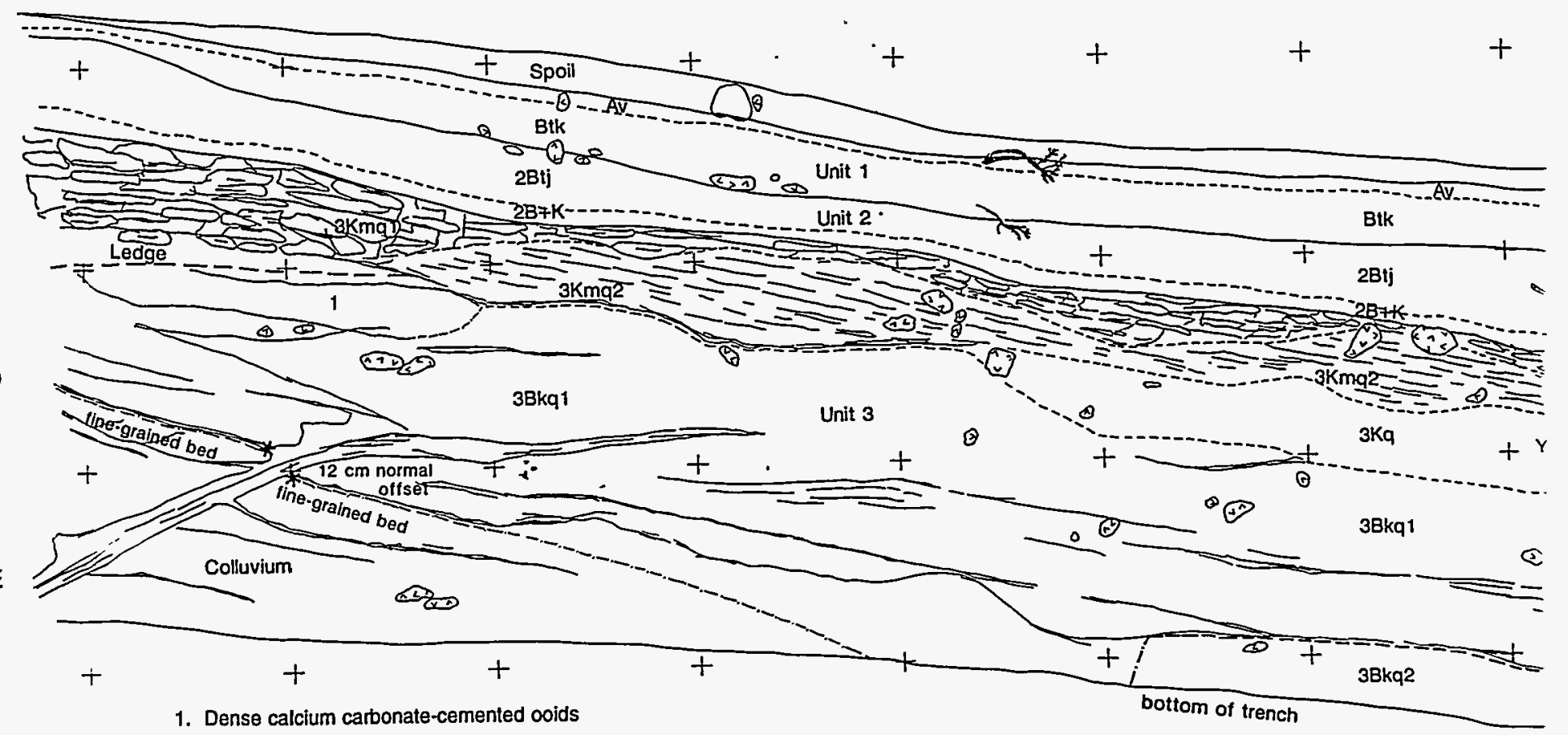

F

2. Filled animal burrow

3. Uncemented, possible filled animal burrow

GRID EQUALS 1 METER SQUARE

$+\quad+\quad+\quad+\quad+\quad+\quad+\quad+$




\section{GEOLOGIC SECTION SHOWING THE MAIN FAULT EXPOSED ON THE SOUTH WALL, CENT TRENCH 14 ON THE BOW RIDGE FAULT AT EXILE HILL, NYE COUNTY, NEVAC}

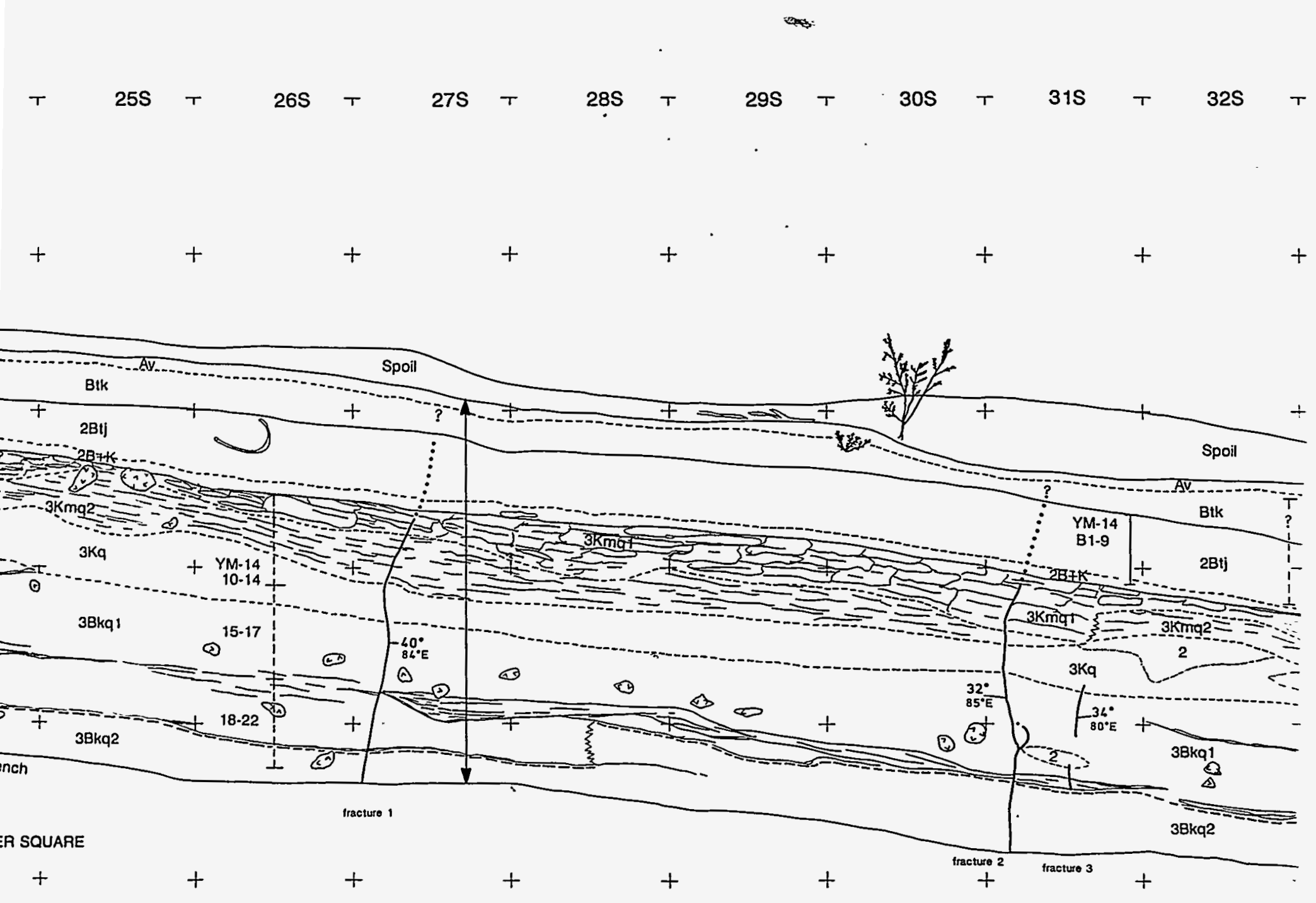




\section{ON THE SOUTH WALL, CENTER SECTION OF E HILL, NYE COUNTY, NEVADA}

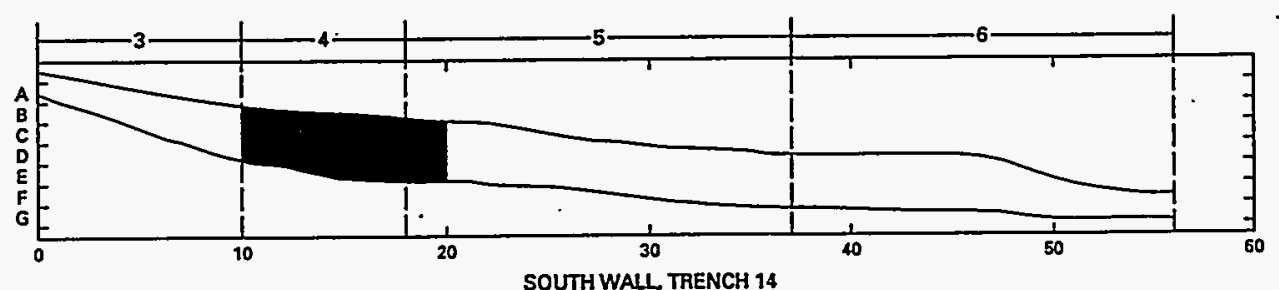

SOUTHWALL, TRENCH 14

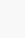


Member (IT), Lithophysae in the Tiva Canyon Member caprock are also less abundant and much more flattened than in the intact Tiva Canyon Member (IT). Caprock contains $16-20$ percent phenocrysts which are primarily sanidine and bronze biotite.

Vein filling (middle Miocene-modern)-Consists of irregularly altemating cemented laminae and vertically to almost horizontally oriented stringers that consist of hard and chalky white carbonate, light gray to very pale brown opaline silica, and weakly cemented white to light gray sand. Veins contain less than 5 percent gravel which are primarily clasts of intact Tiva Canyon Member (IT). Dry consistency varies from extremely hard to loose. Laminae are typically not paired, they do not match in composition or correspond with laminae on either side of the medial zone of the vein(s). Laminae vary in thickness from 0.2 to $10 \mathrm{~cm}$ and are not continuous features for more than 20 to $30 \mathrm{~cm}$. Contacts between carbonate and opaline silica stringers are abrupt. Where opaline silica laminae are adjacent to a breccia unit, contacts tend to be gradational between veins and breccia. Dense opaline silica stringers are most abundant near the center of veins and near contacts with breccia. Maximally carbonate-cemented soil horizons ( $3 \mathrm{Kmq}$ ) within unit 3 drape the bedrock and tend to merge with veins. Magnetic black ash loosely fills some fractures. Ash-filled fractures tend to be near the center of vertically oriented veins, however, ash-filled fractures also may be adjacent to the surrounding bedrock. Fractures containing ash usually crosscut all other laminae in the veins and the maximally developed $\mathrm{K}$ horizons within unit 3. In a few places the ash-filled fractures are cut by a younger lower angle sandy or carbonate-filled vein, or both.

\section{SLOPE-WASH ALLUVIUM AND COLLUVIUM}

Unit 1

Av
Unit 1 (latest Pleistocene to early Holocene)-Pale brown gravelly silty sand, with a soft consistence. Contains moderately sorted, subangular to subrounded sand, and less than 30 percent angular to subrounded pebble cobble gravel. Appears to be mostly eolian, based on the uniform sorting, particle size distribution. and lack of coarse gravel. Secondary carbonate forms thin coatings on the underside of pebbles. Basal contact is wavy. Within unit 1, there are two discrete soil horizons.

Av horizon is a pale brown to dark brown, moderately sorted, silty sand (soil texture: sandy loam) that contains less than 10 percent pebble gravel. Consistence is soft. Basal boundary is abrupt and smooth, and thickness ranges from less than 5 to 10 cm.

$$
\vec{*}
$$

Calcium carboni
generalized. 0
generalized. 0
Opaline silica stri

\section{GEOLOGIC SECTIONS SHOU}


$\equiv$ Calcium carbonate stringers-Schematic. Location and spacing are generalized. Orientation of stringers is accurate

Calcium carbonate platelets-Schematic. Location and spacing are generalized. Orientation of platelets is accurate

1) Opaline silica stringers_-Boundaries are commonly distinct

Recess in wall-Due to collapse, excavation, or open fractures

EAST

$\vdash$

385

D

(1).2. Cobbles and boulders-Composed of tuff

_._-- Lithologic unit boundaries-Solid line where contact is clear. Dashed where inferred. Dot-dashed where transitional

$==-$ Soil-horizon boundaries-Solid line at lithologic discontinuities. Dashed at

soil horizon within the same lithologic unit. Zigzagged at transitional contacts

:

${ }^{353^{\circ}} \mathrm{W} / ?^{\prime} \quad$ Fractures and faults-Strike and dip are recorded in degrees. Dashed and dotted were approximately located. Queried where inferred

Q Fracture faces-Orientation recorded in degrees

$\uparrow$ Soil sample location

* HD-22 Isotope sample location

I-V Main vertical vein numbers $-\mathrm{I}-\mathrm{V}$ on the south wall are correlated to $I+I I$, $\quad I I I+I V$, and $V$ on the north wall

Black ash-filled fractures

in

fractuse 1 Fracture numbers in slope-wash alluvium

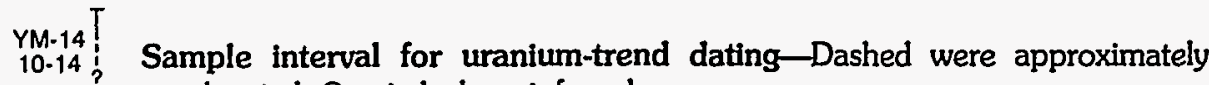
located. Queried where inferred

Plant

Root $\quad:$

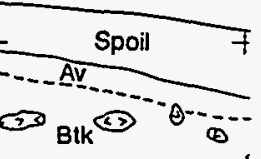

E

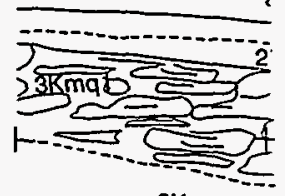

F

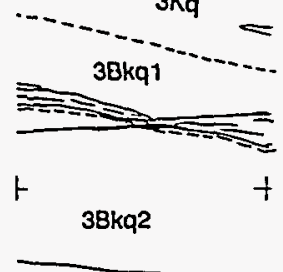

G

1. Filled an:
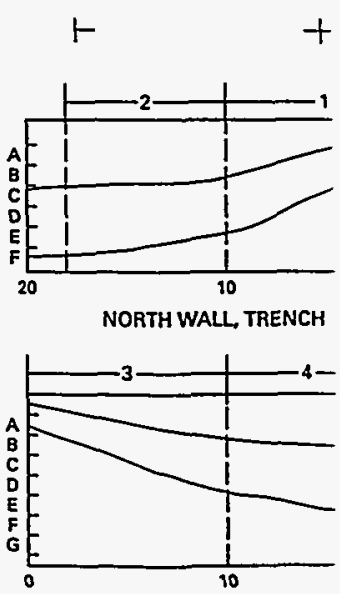
EAST

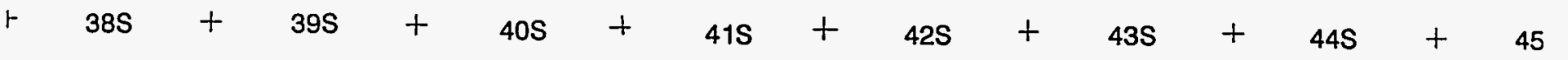

D

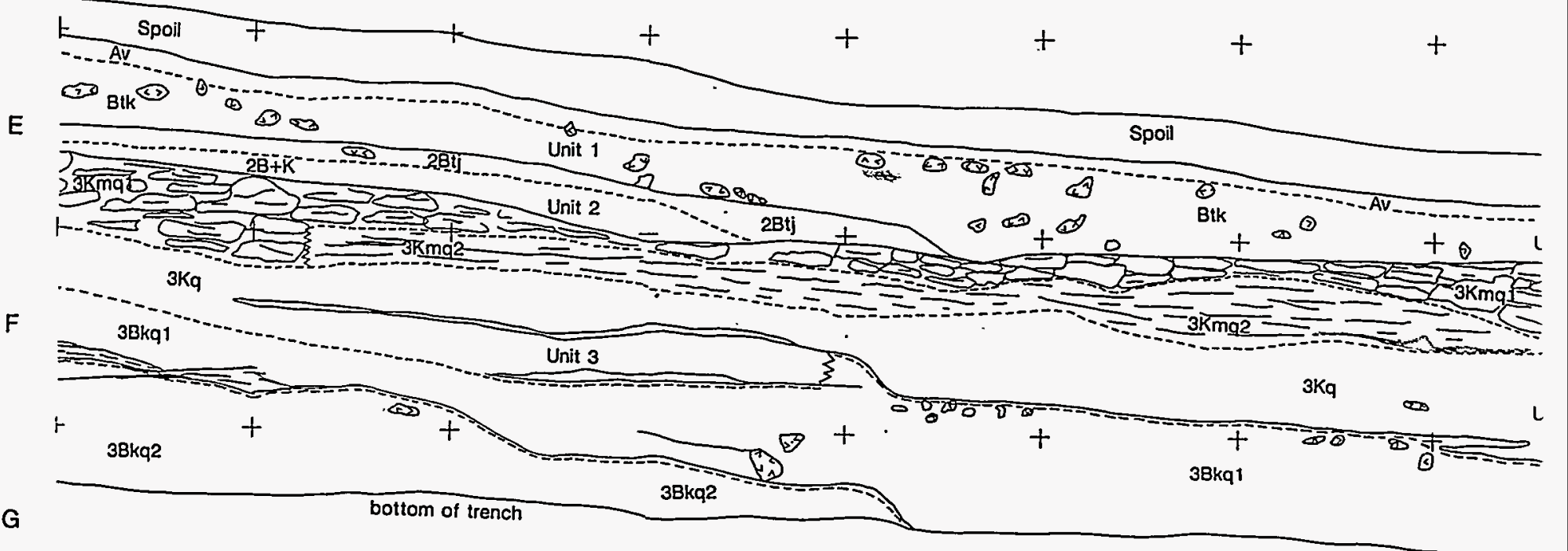

1. Filled animal burrows
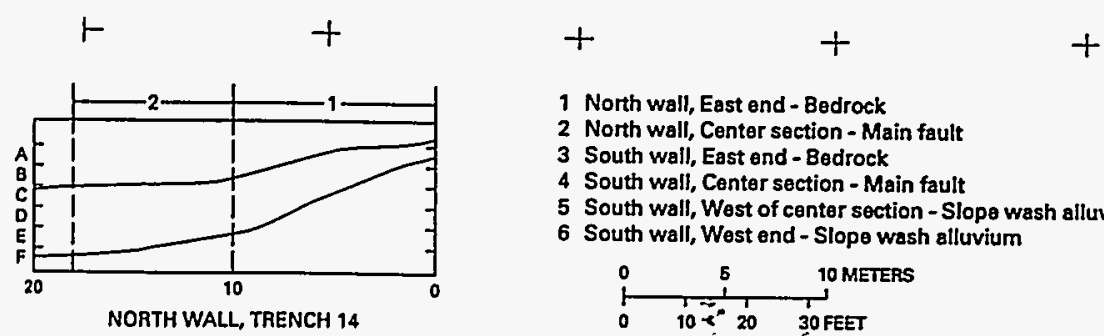

$+\quad+$

GRID EQUALS 1 METER SQUARE

1 North wall, East end - Bedrock

2 North wall, Center section - Main fault

3 South wall, East end - Bedrock

4 South wall, Center section - Main fault

5 South wall, West of center section - Slope wash alluvium

6 South wall, West end - Slope wash alluvium

NORTH WALL, TAENCH 14
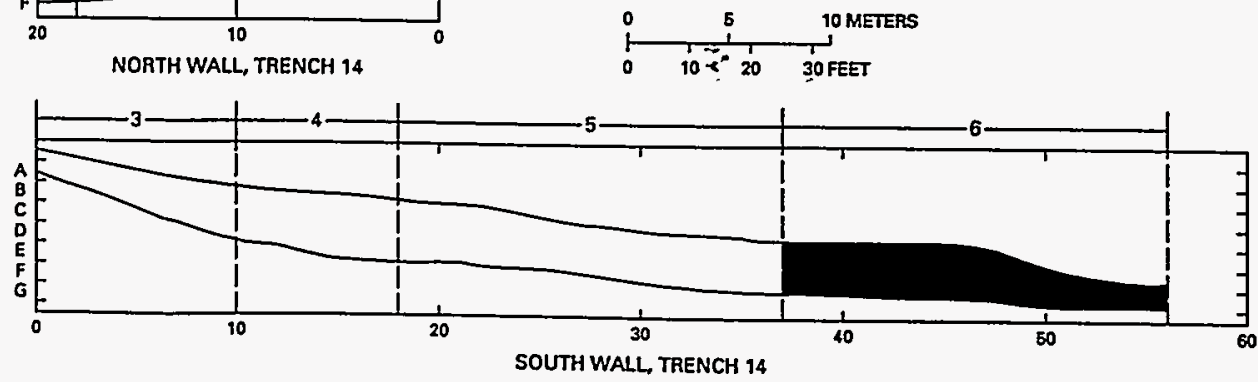

F. GEOLOGIC SECTION SHOWING THE $\subseteq$ WEST END OF TRENCH 14 ON THE 
$50 \mathrm{~S}+51 \mathrm{~S}+52 \mathrm{~S}+53 \mathrm{~S}+54 \mathrm{~S}+55 \mathrm{~S}+56 \mathrm{~S}+{ }^{\text {WEST }}$

D
$+$
$+$
$+$
$+$
$+$

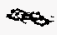

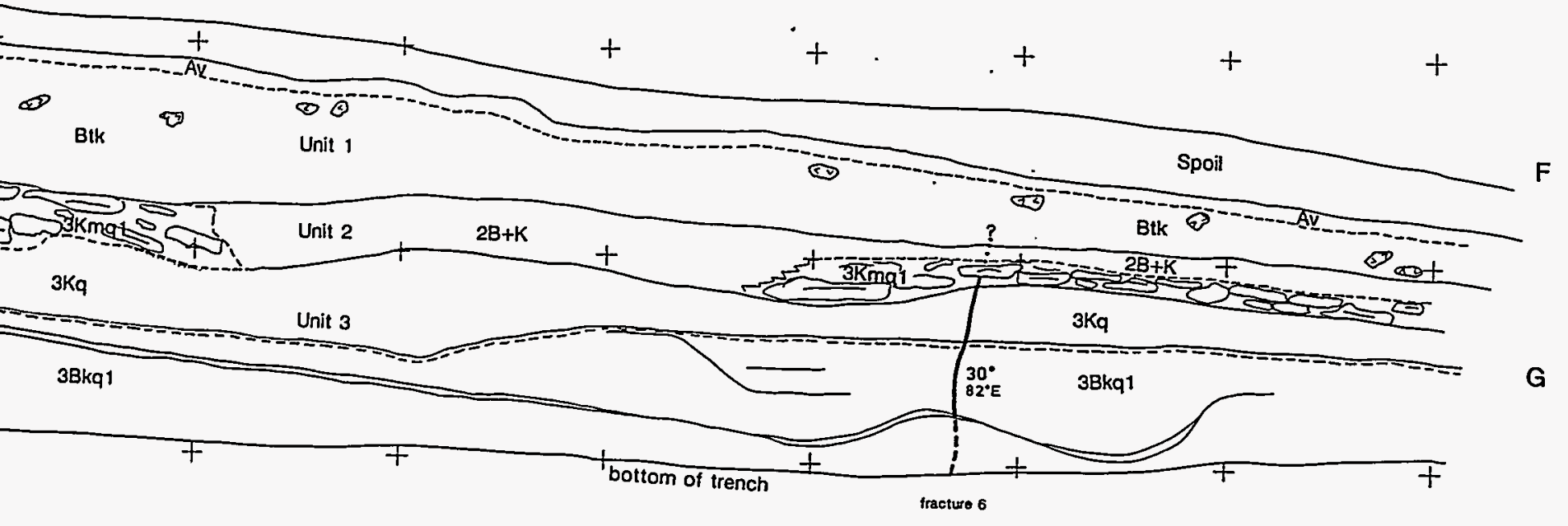

